\title{
norden
}

\section{Tradisjonelle utfordringer - fornyet interesse}

Hvordan er de nordiske landes yrkesutdanninger i stand til å møte arbeidslivets behov? 





\section{Tradisjonelle utfordringer - fornyet interesse}

Hvordan er de nordiske landes yrkesutdanninger i stand til å møte arbeidslivets behov?

Håkon Høst

TemaNord 2012:503 
Tradisjonelle utfordringer - fornyet interesse

Hvordan er de nordiske landes yrkesutdanninger i stand til å møte arbeidslivets behov? Håkon Høst

TemaNord 2012:503

ISBN 978-92-893-2306-2

http://dx.doi.org/10.6027/TN2012-503

(c) Nordisk ministerråd, København 2010

Opplag: 300

\section{Det nordiske samarbeidet}

Det nordiske samarbeid er en av verdens mest omfattende regionale samarbeidsformer. Samarbeidet omfatter Danmark, Finland, Island, Norge og Sverige samt Færøyene, Grønland og Åland.

Det nordiske samarbeid er både politisk, økonomisk og kulturelt forankret, og er en viktig medspiller i det europeiske og internasjonale samarbeid. Det nordiske fellesskap arbeider for et sterkt Norden i et sterkt Europa.

Det nordiske samarbeid ønsker å styrke nordiske og regionale interesser og verdier i en global omverden. Felles verdier landene imellom er med til å styrke Nordens posisjon som en av verdens mest innovative og konkurransekraftige regioner.

\section{Nordisk ministerråd}

Ved Stranden 18

DK-1061 København K

Telefon (+45) 33960200

www.norden.org 
Nordisk ministerråd

Ved Stranden 18

DK-1061 København K

www.norden.org

\section{Tradisjonelle utfordringer - fornyet interesse}

Hvordan er de nordiske landes yrkesutdanninger i stand til å møte arbeidslivets behov?

Moderniseringen av utdanningssystemene har gjort relasjonene til arbeidslivet mer komplekse, og i varierende grad opplever de nordiske landene en avstand mellom den utdanning som gis og behovet arbeidslivet antas å ville ha fremover. De mest fremtredende tiltak synes i denne situasjonen å være:

- I alle de nordiske land, om enn i ulik form, foregår en vending mot å ta virksomhetene mer aktivt i bruk som opplæringsarena for derigjennom å komme tettere på arbeidslivets behov

- Yrkesutdanningene gjøres mer generelle for å gi kandidatene en bredere plattform og bedriftene større fleksibilitet

- Det er en fornyet interesse for bruk av prognoser og andre systematiske planleggingstiltak

Tradisjonelt har de nordiske land tillagt det frie utdanningsvalg stor vekt. Det ser i dag ut til å være to tilsynelatende motsatte bevegelser i ungdoms preferansemønstre: I alle land søker ungdom seg i økende grad søker seg mot studieforberedende utdanninger, samtidig som mange uttrykker mer yrkesspesialisering og praksis. Begge deler kan ses både som uttrykk for ungdoms egen tolkning av arbeidsmarkedets utvikling. 


\section{Innholdsfortegnelse}

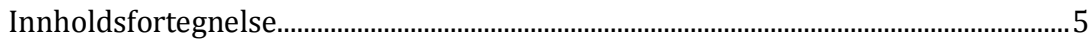

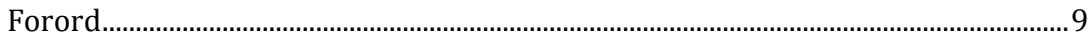

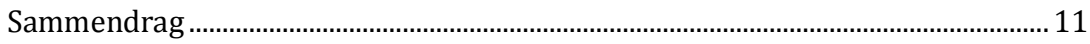

1. Finsk yrkesfagutdanning (VET) og arbeidslivets behov................................... 13

1.1 Bakgrunn.................................................................................................... 13

1.2 Det finske fag- og yrkesutdanningssystemet: mål og organisering ...... 13

1.3 Utviklingen av fag- og yrkesutdanningen i Finland.................................. 16

1.4 Prognoser om forandringer og behov i den finske fag- og yrkesfagkonteksten...................................................................................... 18

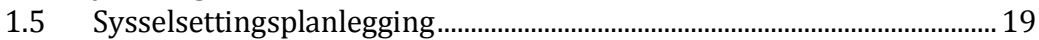

1.6 Framtidsscenarioer og utredninger om kvalifikasjonsbehov................. 20

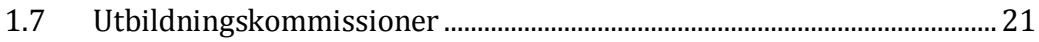

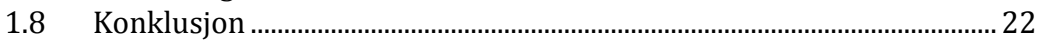

2. De islandske erhvervsuddannelser ..................................................................... 25

2.1 Skiftende vægt mellem parts-, stats- og markedsstyringungdomsuddannelserne samles................................................................... 26

2.2 Erhvervsuddannelserne i ungdomsskole, mesterlære og praktik i

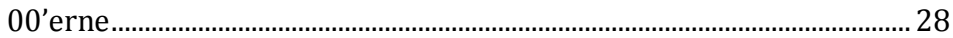

2.3 Lovgivning og institutioner i lyset af hensynet til eksisterende og fremtidige krav på arbejdsmarkedet............................................................. 31

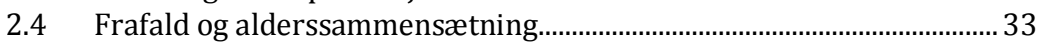

2.5 Misforhold mellem erhvervsudvikling og udvikling af uddannelser ...... 36

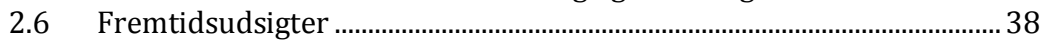

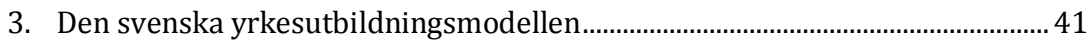

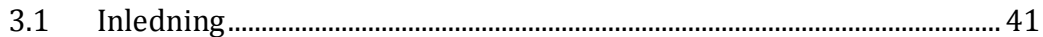

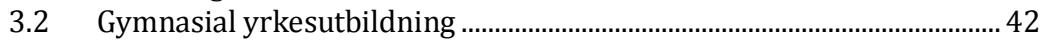

3.3 Avtalsreglerad yrkesutbildning i arbetslivet.............................................. 44

3.4 Yrkesinriktad vuxenutbildning (yrkesvux) ............................................. 45

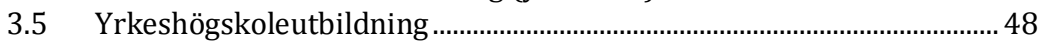

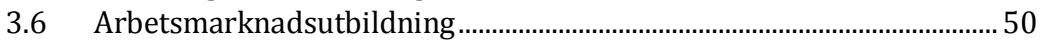

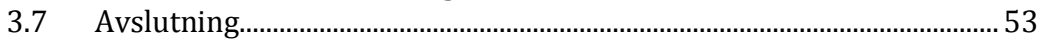




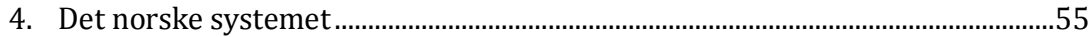

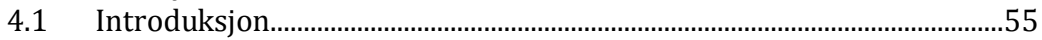

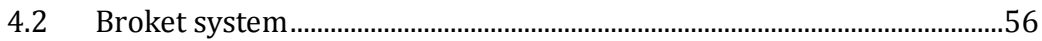

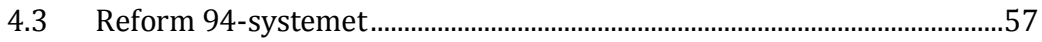

4.4 Korrigeringer gjennom Kunnskapsløftet..................................................58

4.5 Den nye strukturen - noen erfaringer ........................................................61

4.6 Overganger fra yrkes- til studieforberedende .........................................64

4.7 Statlig reformiver, skepsis blant fagene ......................................................65

4.8 Like mange unge rekrutteres utenom lærlingsystemet ...........................66

4.9 Praksiskandidatordningen og fagskolen som fleksibel

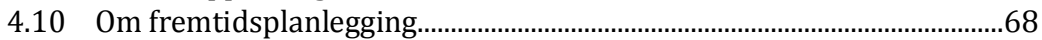

4.11 Oppsummerende drøfting.....................................................................69

5. De danske erhvervsuddannelser og arbejdsmarkedet ........................................71

5.1 Indledning ...................................................................................................

5.2 Hvordan sikres arbejdsmarkedets behov i styringen af uddannelserne? ..........................................................................................

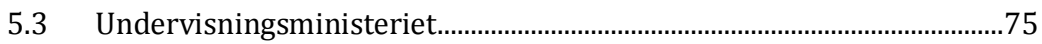

5.4 Rådet for de grundlæggende Erhvervsrettede Uddannelser (REU).........77

5.5 De faglige udvalg.....................................................................................

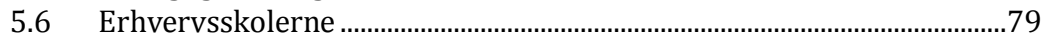

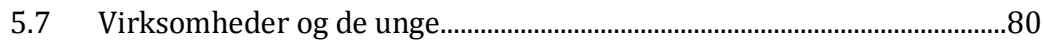

5.8 Voksen- og efteruddannelsessystemet.......................................................81

6. Når tilbudet bestemmer hva man har behov for. Pleie- og omsorgssektoren som case. .......................................................................................83

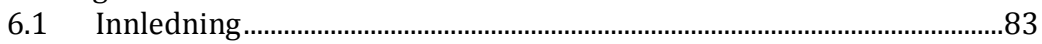

6.2 Komplekse relasjoner i utdanning og arbeidsliv - noen

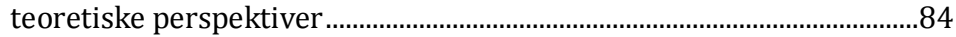

6.3 Sektorens utvikling og utdanningenes særpreg.........................................86

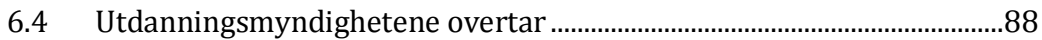

6.5 De kommunale pleie- og omsorgstjenestene vokser fram ......................90

6.6 Fra den mest populære yrkesutdanning til lavstatus på under 10 år.........91

6.7 Utdanningsmyndighetene på banen..........................................................92

6.8 Lærlingordning - hva slags endringer har det gitt?..................................94

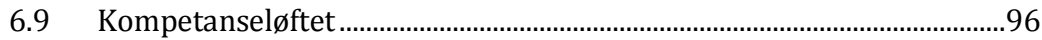

6.10 Rekruttering av ufaglærte fortsatt viktigst ...............................................98 
7. Svensk lärlingsutbildning - förutsättningar och utmaningar ............................101

7.1 Ungdomarnas utbildning och utmaningar för samhällsekonomin .....101

7.2 Lärlingsutbildningens historia och förutsättningar ...............................103

7.3 Lärlingsutbildningens betydelse - en fördjupning..................................108

7.4 Lärlingsutbildningen och arbetsmarknadens reglering .........................112

7.5 Internationella erfarenheter....................................................................115

7.6 Lärlingsutbildning i Sverige .................................................................116

7.7 Frågetecken kring den nya lärlingsutbildningen i Sverige ....................119

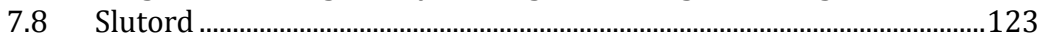

8. Lærlinge-uddannelsers koblinger til arbejdsmarkedet....................................125

8.1 Koblinger gennem det faglige selvstyre...................................................126

8.2 Koblinger via vekseluddannelser...............................................................128

8.3 Koblinger gennem kvalifikationsanalyser ..............................................132

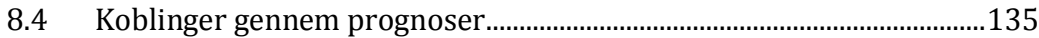

8.5 Frafald i erhvervsuddannelserne............................................................136

8.6 Lighed i adgangen til uddannelse og arbejde ...........................................137

8.7 Lærlingeuddannelsernes styrker og svagheder .....................................138

9. Tradisjonelle utfordringer - fornyet interesse ....................................................143

9.1 Hva skyldes den nye interessen? ............................................................143

9.2 Ulike systemer - felles utfordringer? ......................................................145

9.3 Fastsettelse av kompetansekrav ikke nøytralt .......................................146

9.4 Kunnskapsklynger som alternativt utgangspunkt?................................148

9.5 Er tilbud om læreplasser et uttrykk for arbeidslivets behov? ............151

9.6 Island: Store svingninger gjør planleggingen utfordrende....................152

9.7 Den finske «prognoseindustrien»............................................................153

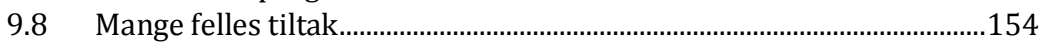

9.9 Hva slags og hvor høy utdanning er det behov for? ...............................156

9.10 Koplinger til allmennutdanningen. Styrke eller trussel?.......................157

9.11 De voksne som avgjørende ressurs for arbeidslivet..............................159

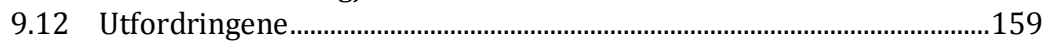

Referanser. 



\section{Forord}

I november 2009 fikk NIFU Nordisk institutt for studier av innovasjon, forskning og utdanning i oppdrag fra Nordisk Ministerråd om å «gjennomføre en studie om sammenhengen mellom fremtidens kompetansebehov og innhold i og utforming av yrkesutdanningene i de nordiske land inkludert de selvstyret områdene.» Oppdraget ble av ulike årsaker først igangsatt sommeren 2010 og har blitt løst gjennom at forskerne fra de ulike har land har skrevet hvert sitt bakgrunnskapittel om relasjonen mellom de enkelte lands yrkesutdanningssystemer og arbeidsmarkedets behov. Disse ble så kommentert og drøftet forskerne i mellom, samt av yrkesgruppen i Nordisk Ministerråd. Deretter ble noen sentrale temaer på tvers av land forfulgt og drøftet i egne kapitler.

Håkon Høst fra NIFU har vært prosjektleder og redigert antologien. De som for øvrig har bidratt er Sakari Ahola fra Universitetet i Turku, Gestur Gudmundsson fra Islands Universitet, Jonas Olofsson, Umeå Universitet, Eskil Wadensjö fra Stockholms Universitet, Aleksandru Panacin fra Lund Universitet, og Christian Helms Jørgensen Roskilde Universitetscenter. Ved NIFU har Asgeir Skålholt bidratt i oversettelsen av det finske bidraget fra svensk til norsk, og Hilde Karlsen har bidratt til å rydde og formatere stoffet.

Temaet er omfattende og landene har svært ulike systemer på dette området. I en såpass begrenset studie vil det være lite rom for ny datainnhenting. I noen grad har samtaler med representanter for utdanningsforvaltningen i ulike land vært benyttet for å klargjøre forhold. Forørvig har forskerne basert seg på dokumentanalyse og den eksepertise de har opparbeidet på feltet gjennom årelang forskning på yrkesutdanningsfeltet. 
Vi vil for øvrig rette en spesiell takk til representanene for yrkesgruppen i Nordisk Ministerråd for deres engasjement og tilbakemeldinger underveis i prosessen.

Oslo 1. november 2011

Håkon Høst, prosjektleder, NIFU 


\section{Sammendrag}

I denne antologien presenteres og drøftes hvordan de nordiske lands yrkesutdanningssystemer er utformet for å ta opp i seg arbeidslivets behov for arbeidskraft. Moderniseringen av landenes utdanningssystemer har gjort relasjonene til arbeidslivet mer komplekse, og i varierende grad opplever landene en mismatch mellom den utdanning som gis og behovet arbeidslivet har og antas å ville ha i årene som kommer.

Det er vanskelig å snakke om noen felles, nordisk modell som også påvirker hvordan arbeidslivets behov formidles til yrkesutdanningssystemene. Man kan snakke om noen felles trekk, som på den ene siden arbeidsmarkedspartenes innflytelse, og på den annen betydningen av en velferdsstatlig politikk for lik rett til utdanning og full sysselsetting. Men både vektleggingen av disse momentene, og veldig mye for øvrig er svært forskjellig. De fem nordiske land har ulike systemer for yrkesutdanning, og interessestrukturene rundt yrkesutdanningene er heller ikke like, noe som igjen legger grunnlag for store forskjeller i hvordan arbeidslivets behov formidles. I Danmark og til en viss grad Norge har arbeidslivspartene tatt et stort ansvar for yrkesopplæringen, både når det gjelder organisering, tariffering og økonomi, mens man i de øvrige andre land i større grad har sett dette som statens oppgave.

Mens Danmark og til en viss grad Norge og Island har betydelige lærlingordninger, er Finland og Sverige utpregede skoleland. Dette gir landene ulike utgangspunkt når det gjelder tilpasningen av yrkesutdanningen til arbeidslivets behov.

I dagens situasjon kan man identifisere noen sentrale tiltak rettet mot det å bedre yrkesutdanningenes relevans i arbeidslivet på kort og lang sikt. Det gjelder vendingen mot å ta virksomhetene mer aktivt i bruk som opplæringsarena for derigjennom å komme tettere på arbeidslivets behov. Det gjelder tiltak rettet mot å gjøre yrkesutdanningene mer generelle slik at de gir kandidatene en bredere plattform for omstilling og videre livslang læring, og bedriftene større fleksibilitet. Og det gjelder ikke minst den 
nye fokuseringen på bruk av prognoser og andre systematiske planleggingstiltak. Vi ser at alle land tar i bruk alle disse tiltakene, om enn i ulik grad ut fra særegne forhold. Sverige, som har den svakeste tradisjonen for lærlingutdanning og fag, har satt i gang et offensivt forsøk med en slik ordning knyttet til de grunnleggende yrkesutdanningene. Finland, som også har en sterk skoletradisjon, men samtidig en ganske spesialisert struktur, er det land som i størst grad legger vekt på å utvikle modeller for behovsberegninger og prognoser som kan danne grunnlaget for videreutvikling av den spesialsierte skolestrukturen. Island, som har opplevd de kraftigste svingningene i arbeidsmarkedet, satser på alle virkemidler, både mer generelle utdanninger, styrking av lærlingordningen og prognosearbeidet. Danmark og Norge prioriterer fagopplæring og lærlingordninger, men er på jakt etter måter å gjøre disse mer responsive overfor arbeidslivets behov og endringskrav.

Ungdommens egne ønsker er en joker i dette planleggingsarbeidet, ikke minst med den sterke vekten de nordiske land tradisjonelt har tillagt det frie utdanningsvalg. En overgripende tendens er at ungdom i større grad søker seg mot studieforberedende utdanninger. Men det finnes også andre tendenser, som at ungdom som søker yrkesutdanninger ofte etterspør yrkesspesialisering og praksis. Begge deler kan ses både som uttrykk for ungdoms egen tolkning av arbeidsmarkedets utvikling, og som et signal til yrkesutdanningene og virksomhetene om at de også må tilpasse seg søkertilbudet. 


\section{Finsk yrkesfagutdanning (VET) og arbeidslivets behov}

Sakari Ahola, Universitet i Turku

\subsection{Bakgrunn}

I løpet av etterkrigstidens sterke økonomiske vekst i Finland, som karakteriseres ved lønnsarbeid, masseproduksjon, utdanning for alle og full sysselsetting, utviklet det seg et system hvor fag- og yrkesutdanning ble organisert i egne skoleløp adskilt fra arbeidslivet (Ahola 2006).

Den raske og uavbrutte utviklingen av fag- og yrkesutdanning har ikke hindret at feltet stadig har blitt kritisert for verken å oppfylle kompetanseog ferdighetskravene i arbeidslivet eller i utdanningssfæren. Denne kritikken har spesielt vært sterk i tider hvor arbeidsledigheten blant ungdom har vært økende, og hvor fag- og yrkesopplæring har vært viktigere i arbeidsmarkedet. Etter den økonomiske nedgangstiden på begynnelsen av 1990-tallet ble fag- og yrkesutdanning reorganisert for å kunne øke relevansen i arbeidsmarkedet, sammenliknbarheten i Europa - og mer nylig utvikling av læreplaner og innhold fokusert på læringsutbytte.

\subsection{Det finske fag- og yrkesutdanningssystemet: mål og organisering}

Hovedformålet for det finske fag- og yrkesopplæringssystemet er beskrevet $\mathrm{i}$ «Lov om yrkesutdanning» $(630 / 1998)$ som sier at fag- og yrkesutdanningens mål er å gi eleven den kompetanse og de ferdigheter som kreves for å få fagkompetanse, og å gi dem kunnskap om hvordan de kan skape sin egen arbeidsplass (entreprenørskap). Loven sier videre at man $\mathrm{i}$ 
organiseringen av fag- og yrkesutdanning må ta hensyn til behovene $\mathrm{i}$ arbeidsmarkedet, og utdanningssystemet skal samarbeide med arbeidsgiverne og representanter for arbeidslivet.

Den tilsvarende loven innenfor voksenopplæring (631/1998) sier at i tillegg til oppdatering og videreutdanning av voksnes kompetanse og ferdigheter, skal også voksenopplæringen gi muligheter for karriereutvikling, og fremme sysselsetting. Voksenopplæringen bør også stimulere voksne til å fullføre formell utdanning. I utviklingen av læreplaner for voksenopplæring er behovene til arbeidslivet spesielt viktige, og organiseringen og innholdet $\mathrm{i}$ kompetanseprøve skal utformes i nært samarbeid med arbeidsgiverne.

Utdannings- og kulturdepartementet gir utsteder lisenser til å gjennomføre fag- og yrkesopplæring, og det er spesielt kommuner, samt organisasjoner og foretak dannet av kommuner eller andre, som står for denne opplæringen. I 2008 var det 214 tilbydere av fag- og yrkesopplæring, og 285 individuelle fag- og yrkesopplæringsinstitutter i Finland. Antallet elever i ordinær yrkesutdanning var 127 300. Når vi inkluderer voksenopplæring og lærlingutdanning var det totale antallet 275500 (se tabell 1).

Tabell 1: Elever og eksamener i fag- og yrkesopplæring, etter utdanningstype, 2008

\begin{tabular}{lcccccc}
\hline & \multicolumn{2}{c}{ Yrkesutdanning i skole } & Lærlingutdanning & & SUM \\
& Elever & $\begin{array}{c}\text { Avlagte } \\
\text { eksamener }\end{array}$ & Elever & $\begin{array}{r}\text { Avlagte } \\
\text { eksamener }\end{array}$ & Elever & $\begin{array}{r}\text { Avlagte } \\
\text { eksamener }\end{array}$ \\
\hline $\begin{array}{l}\text { Ordinær yrkesut- } \\
\text { danning }\end{array}$ & 127284 & 32458 & 322 & 66 & 127606 & 32524 \\
$\begin{array}{l}\text { Utdanning med } \\
\text { kompetanseprøve }\end{array}$ & 34150 & 6715 & 31274 & 4001 & 65424 & 10716 \\
$\begin{array}{l}\text { Videreutdanning } \\
\text { Yrkesspesialisering }\end{array}$ & 36922 & 9376 & 22042 & 4893 & 58964 & 14269 \\
All & 7105 & 1756 & 16399 & 3233 & 23504 & 4989 \\
\hline
\end{tabular}

Kilde: Statistics Finland 2010

Fag- og yrkesopplæring tilbys innenfor åtte brede fagfelt. Fagområdet teknologi, kommunikasjon og transport er det klart største med et årlig inntak på omlag 27000 elever. Sosiale tjenester, helse og idrett, er nest 
størst med 12000 nye elever i 2008. Humanistiske fag og utdanning er et relativt lite område med et årlig inntak på om lag 1000 nye elever.

Den finske utbildningsstyrelsen (UBS) fastlegger en felles læreplan for hvert fagområde. Denne inneholder blant annet de grunnleggende allmennog yrkesfaglige læreplanmål, det vil si hva elevene må kunne, eller læringsutbytte. Læreplanene blir utformet i tett samarbeid med arbeidsgiver- og arbeidstakerorganisasjonene, samt representanter for elevene. Per i dag er det 54 grunnleggende yrkeskvalifikasjoner og 118 opplæringsprogram. Læreplanen skal være utformet slik at utdanningen gir grunnleggende yrkesfaglige ferdigheter tilpasset forskjellige områder innenfor et fagområde, samt spesiell kompetanse innenfor bestemte yrker innen fagområdet. Den nasjonale læreplanen inkluderer også en generell del, hvor nøkkelkompetanser som grunnlag for livslang læring er særlig viktig i denne sammenheng. Dette inkluderer viktige grunnleggende arbeidslivsferdigheter, som problemløsning, samarbeid og teamarbeid, yrkesetikk, HMS, kommunikasjon og mediaforståelse, aktivt medborgerskap og kulturforståelse.

Man kan bli kvalifisert yrkesfaglig gjennom ordinær yrkesfaglig opplæring basert på den felles læreplanen, eller gjennom å bli vurdert ved en kompetanseprøve (yrkesprov) noe som tradisjonelt har vært en voksenopplæring, men som ble innført i all ungdomsutdanning fra 2006. Kompetanseprøvene er en fleksibel måte å få yrkesfaglig kvalifikasjon på, ved å kombinere skole, arbeidsbasert læring og tidligere erfaring. Yrkesfaglige programmer som leder mot kompetanseprøver har en egen læreplan. I tillegg kan alle yrkeskvalifikasjoner oppnås gjennom å være lærling.

Den enkelte tilbyder av utdanning fastsetter selv innholdet i den lokale læreplanen, men i overensstemmelse med den nasjonale læreplanen. Den lokale tilpasningen kan også inkludere samarbeid med lokale bedrifter. I tillegg kan alle elever ha egne, individuelt tilpassede læreplaner.

Den grunnleggende strukturen og rammen for yrkesfaglig opplæring blir bestemt av det ansvarlige departement. Omfanget av opplæringen er 120 studiepoeng (som tilsvarer tre år fulltidsstudie), og det inkluderer et minimum av 20 studiepoeng arbeidsbasert læring. Målet for den praktiske delen, er at elvene kan bli kjent med og oppnår de grunnleggende ferdigheter i et yrke slik det er beskrevet i læreplanen. Et annet mål er å øke elevenes muligheter på arbeidsmarkedet. Det er også et mål at arbeidslivets krav til kompetanse blir formidlet til yrkesskolene gjennom en felles 
organisering av den praktiske delen av utdanningen, og gjennom andre former for arbeidsbasert læring.

\subsection{Utviklingen av fag- og yrkesutdanningen i Finland}

Det grunnleggende dokumentet for finsk utdanning, er «Utviklingsplan for utdanning og forskning» (MoE 2007). Den gjeldende planen er for 2007 til 2012 og sier følgende om utviklingen av fag- og yrkesopplæringen:

- Systemet for yrkeskvalifikasjoner vil bli utviklet som en helhet gjennom å kombinere kvalifikasjonsbehovene til den enkelte og til arbeidsgivere, slik at kvalifikasjoner blir definert ut fra læringsutbytte og relaterer seg til oppgaver i arbeidslivet

- Samsvaret mellom yrkeskvalifikasjonene og arbeidslivets behov vil bli styrket gjennom utvikling både av områdespesifikke kompetanser, grunnleggende ferdigheter og kompetanse for livslang læring

- Mer fleksible måter å oppnå yrkesfaglig kompetanse vil bli utviklet gjennom å introdusere modul-strukturer hvor eksamen kan nås gjennom en kombinasjon av arbeid og skole

- Fleksibiliteten skal økes gjennom å tillate at deler fra andre yrkesutdanninger inkluderes i den felles læreplanen for de ordinære yrkesutdanninger

- Den praksisbaserte læringen skal styrkes ved å utvikle praktisk trening, kompetanseprøver, og lærlingopplæring slik at det legges særlig vekt på veiledning på arbeidsplassen og kvalitetskontroll

I følge EUs utdanningspolitikk, skal yrkesfaglige kvalifikasjoner defineres ut fra læringsutbytte. Finland har vært ledende på dette området, og i 2010 la regjeringen fram et forslag om et nasjonalt kvalifikasjonsrammerverk for Riksdagen(HE 165/2010 vp). I rammeverket er ordinær yrkesutdanning lagt til nivå 4, og fagspesialistutdanning lagt til nivå fem. Til sammenligning er høyere utdanning lagt til nivå seks (bachelor), sju (master) og åtte (phd). 
Rammeverkets bredde og generelle karakter gjør at også definisjonene av læringsutbytte også er brede og generelle og til tider vage og åpne for ulike tolkninger. På en måte gjenspeiler og reproduserer forslaget de gamle ISCED-nivåene. ${ }^{1}$ Man har derfor her de samme problemene med å definere og skille «reelle» forskjeller i nivå fra statushierarkier. Konklusjonen er at kvalifikasjonsrammeverket vil være lite nyttig for utviklingen av en mer arbeidslivssensitiv læreplan. Utfordringen blir hvordan man i den lokale læreplanen på en meningsfull måte kan formulere læringsutbytte i utdanninger, skole, oppgaver, praksisbaserte lærlingsmoduler osv., som er genuint «utbyttebasert».

Som påpekt tidligere, er de grunnleggende dokumentene som beskriver læringsutbytte ut fra hva som trengs i arbeidslivet, den nasjonale og den lokale læreplanen. Disse ble fornyet i perioden 2008 til 2010. For best mulig å integrere arbeidslivets behov, arbeidet den finske utbildningsstyrelsen $^{2}$ tett sammen med utbildningskommissioner, prøvenemnder og andre interessenter. Evalueringen av den forrige læreplanreformen (1999-2001) konkluderte med selvom samarbeidet mellom yrkesutdanningen og arbeidslivet har økt, så er deltakelsen fra arbeidslivet i utformingen av de faktiske læreplanene relativt lav. På denne tiden var overgangen fra fagbasert til arbeidsoppgavebasert planlegging ikke kommet så langt, og dette ble ikke integrert i den generelle læreplanen (FNBE 2004).

Prinsippene i de nye læreplanene 2008-2010:

- Sterkere arbeidslivsrelevans

- Man utdanner for den kompetanse som trengs i arbeidslivet og i videreutdanning

- Man anerkjenner tidligere oppnådd kompetanse

- Arbeidslivet deltar i bedømningen av kompetansen og pørven utføres ofte på en arbeidsplats

- Fleksible, alternative utdanningsveier

${ }^{1}$ International Standard Classification of Education. http://www.unesco.org/education/

2 Finnish National Board of Education (FNBE). 
- Det gis muligheter til å avlegge deleksamener og velge enkeltdeler fra andre læreplaner gjennom individuelle valg

- Muligheter for å velge kombinasjonsstudier med deler fra det teoretiske gymnasiet gjennom individuelle valg

- Større muligheter for fordypning gjennom individuelle valg

- Utbildningstilbyder kan tilpasse eksamen til lokale behov

- Utdanning og arbeidsliv kan veksle, studiene kan i sin helhet utføres på en arbeidsplass

Det å øke arbeidslivsinnretningen av yrkesutdanningene har stått på dagsorden helt siden systemets etablering. Dette har resultert i et stort antall prosjekter, organer, tiltak og metoder rundt det vi kan kalle «prognoseindustrien». Det mangler et utgangspunkt for å måle suksessen til alle disse aktivitetene. Det eneste målet vi har på om en prognose har vært riktig er sysselsettingsstatistikken. Slik det nå er, mottar tilbydere av yrkesfaglige utdanninger resultatbasert finansiering, hvor ett av kriteriene er i hvor stor grad deres elever oppnår ansettelse i arbeidslivet. Det er imidlertid ikke noen helt klar sammenheng mellom det at en kandidat får ansettelse eller ikke og kvaliteten på utdanningstilbudet. Vi skal i det videre se på utfordringer ved nettopp å benytte prognoser som den viktigste tilnærmingen.

\subsection{Prognoser om forandringer og behov i den finske fag- og yrkesfagkonteksten}

På nasjonalt plan inkluderer prognosesystemet planlegging av framtidig arbeidsstyrke, framtidig kompetansebehov gjennom egne prosjekter, prosjekter støttet av European Social Fund (ESF) og utbildningskommissioner. Disse instansene både produserer og videreformidler informasjon om arbeidsstyrken, arbeidsmarkedet, yrker og kompetansekrav, som grunnlag for planleggingen av yrkesutdanningen. På lokalt nivå er hovedansvaret for prognosene lagt til sentre for økonomisk utvikling, transport og miljø (ELY-sentre) og til landskapsförbund. Lokale tilbydere av yrkesutdanninger har også forskjellige samarbeidsorganer som deltar i utarbeidelsen av pensum og I organiseringen av praktisk trening. 


\subsection{Sysselsettingsplanlegging}

En sentral planlegging av utdanningen basert på sysselsettingssituasjonen har en lang og sterk tradisjon i Finnland. I de senere år har slike prognoser blitt ytterligere komplekse - de inkluderer forskjellige komponenter fra enkel modellering basert på ekstrapolering av trender til forskningsbaserte framtidsscenarioer. Den viktigste informasjonen kommer fra arbeidsmarkedsframskrivinger basert på behovet i forskjellige næringer og yrker, samt naturlig avgang. De mer utdypende modellene inkluderer anslag om hvilke kompetanse forskjellige yrker vil kreve i framtiden, basert på forskjellige scenarier om global markedsutvikling, framvoksende næringer og nye typer utdannings- og kvalifikasjonsbehov.

De enkle arbeidsmarkedsframskrivingene baserer seg i hovedsak på anslag om økonomisk vekst, noe som har blitt stadig vanskeligere på grunn av globaliseringen av verdensøkonomien; små endringer i de utvalgte parametere vil dermed få store konsekvenser for dimensjoneringen av utdanningstilbudet. For eksempel har den nåværende planen for 2020 en forskjell mellom grunnleggende scenarier og målscenarier på omtrent 8000 kandidater per år. Målscenariet, som baserer seg hovedsakelig på en sterkere økonomisk vekst, bør også ta opp i seg et grunnleggende prinsipp i finsk utdanningspolitikk; nemlig det å skaffe alle grunnskolekandidater yrkeskvalifikasjoner enten fra det videregående nivå eller gjennom høyere utdanning (MoE 2007).

En annen problematisk side ved prognosemetoden er knyttet til de såkalte yrkesutdanningsnøklene. Dette er en metode som oversetter arbeidsmarkedsbehovet til faktisk output fra utdanningsinstitusjonene. Disse nøklene gjør rede for hvilke utdanningskvalifikasjoner, delt inn i fagfelt og nivå, framtidige arbeidstakere i forskjellige yrker vil trenge. Denne modellen inneholder en beskrivelse av hvordan matchen mellom utdanninger og arbeidsmarked er i øyeblikket, sammen med en mer kvalitativ del, som ser på framtidig kompetansebehov ut fra de beskrevne nøklene. I utgangspunktet skal da hver nøkkel inneholde bare relevante utdanninger for et bestemt yrke. Problemet er at man i det virkelige liv ikke alltid finner et slikt 1:1 forhold mellom utdanning og arbeid.

Gjennom en politisk prosess danner resultatet av disse analysene grunnlaget for en utviklingsplan for utdanning og forskning. Den komp- 
lekse prosessen bak tallene i denne planen gjør at det mangler transparens i forhold til formålene, konkluderer den finske riksrevisjonen i sin rapport om kvantitative prognoser (NAOF 2008). En enda større svakhet er at planleggingsprosessen mangler adekvate elementer av oppfølging og selvevaluering. Denne «planleggingsmaskinen» går rutinemessig periode etter periode der nye estimater blir gjort tilgjengelig uten at oppfølging og analyser av den forrige runden foreligger. Revisjonen viser også til at målene som er lagt i utviklingsplanen har for svak tilknytning til andre mål som myndighetene har satt seg. Revisjonsrapporten viser at det kan være en risiko for iverksetting av politikk og tiltak som er innbyrdes motstridende i utdanningsfeltet. Som følge av disse problemene svekkes styringsfunksjonen til utviklingsplanen.

\subsection{Framtidsscenarioer og utredninger om kvalifikasjonsbehov}

Framtidsscenarioer for kvalifikasjonsbehov ser på utviklingen innen forskjellige felt og yrker. I perioden 2005 til 2010 bestilte den finske utbildningsstyrelsen i alt 13 slike scenarioer innen fagfelt som natur og miljø, catering, ungdom og fritidsrådgiving, papirindustri og audiovisuell kommunikasjon. I tillegg har det vært en rekke andre prognoseprosjekter. Gjennom ESF-programmet 2000-2006 finansierte utdanningsdepartementet 36 forskjellige slike prosjekt (Foredata 2008). Disse prosjektene brukte forskjellige metoder, de fleste av dem kvalitative, for å sondre framtidig endring i arbeidslivet. Prosjektene så på jobb-beskrivelser, arbeidsforhold og metoder, og de tilhørende kompetansekrav. Kvalifikasjonsscenarier forsyner arbeidsmarkedsplanleggingen med informasjon, men kan også benyttes i læreplanarbeid, nasjonalt og lokalt.

Problemet med disse scenarioene og utredningene er at de er lite omfattende og baserer seg nesten kun på ekspertintervjuer med de mest kjente aktørene innenfor de aktuelle fagområdene. På denne måten har scenariene en tendens til å reprodusere generelle oppfatninger om økonomisk vekst, informasjonssamfunnet, innovasjoner og entreprenørskap som er viktig for konkurranseevnen på nasjonalt nivå. Arbeidet med disse scenarioene er også potensielle fora for profesjonelle og semi-profesjonelle interesser som ønsker 
å sikre sin del av utdanningsressursene. Informasjonen som disse scenariene tilbyr blir sjelden omsatt til faktiske tiltak når det gjelder dimensjonering og læreplaner. Dette er særlig et problem i sceniarier som ser på hvordan globale endringer påvirker det nasjonale yrkesutdanningssystemet.

For å utvikle og bedre ta i bruk det enkelte scenarioarbeidet, lanserte den finske utbildningsstyrelsen i 2008 et ESF-finansiert prosjekt (VOSE) for å utvikle et rammeverk for kvalifikasjonsscenarier som var anvendbart for alle yrkesfelt, og på alle utdanningsnivå. Prosjektet satte i gang to pilotstudier innen helse og omsorg, og eiendom og bygg. Som en gjennomgående metode vil prosjektet basere seg på en kunnskapsklyngetilnærming. I følge en underlagsrapport bestilt av utbildningsstyrelsen, og som så på eiendom og bygg, så inneholder fagfeltet flere ulike aktører og interessenter som har mye ekspertise og mange kunnskapskilder som kan brukes i prognosearbeidet. I tillegg kan de ulike organisasjonene og fagforeningene knyttet til kunnskapsklyngene også komme med egne prediksjoner og prognoser på kort og lang sikt som kan integreres i det helhetlige prognosearbeidet (Foredata 2009). Hvordan dette vil innvirke på og forbedre prognosearbeidet gjenstår å se.

\subsection{Utbildningskommissioner}

Systemet med egne utbildningskommisjoner for utarbeiding av generelle planer og prognoser for yrkesutdanninger skriver seg fra slutten av 1980tallet. Det ble fornyet i 2010. Fra 2011 finns det 26 utbildningskommissioner for ulike bransjer. En styringsgruppe koordinerer arbeidet. Kommissionene er rådgivende trepartsorgan. De skal innenfor sine respektive kompetanse og virksomhetsområder:

- Følge opp, vurdere og stille prognoser for kompetansebehovet i utdanning og arbeidsliv

- presentere forslag for undervisnings- og kulturdepartementet, Utbildningsstyrelsen og andre sentrale aktører i den hensikt å utvikle den yrkesrettede utdanningen (yrkes-, yrkeshögskole- og universitetsutdanning) 
- Presentere forslag for högskolene om arbeidslivets kompetansebehov $\mathrm{i}$ forhold til utdanningenes innhold

Styringsgruppen kan opprette ekspertgrupper, som tar for seg den kvalitative prognostiseringen i ett eller flere kompetense- og virksomhetsområder. Selv om utbildningskommissionenes medlemmer er eksperter innenfor deres egne fagfelt, er de sjelden spesialister på statistikk, informasjonssystemer og metodene som ligger til grunn for prognosene. Derfor anbefales det at komiteene skal ha støtte og opplæring utenfra. Med bakgrunn i de manglene man har i kunnskapsbasen for prognosen, lister en intern rapport opp flere punkter, slik som: for dårlig oppdatert statistikk, vanskeligheter med å få informasjon om små fagfelt og yrker (klassifiseringsproblemer), manglende statistikk om nye og kommende fagfelter, problemer med sammenlikninger over tid og inkonsistens mellom forskjellige statistikkilder. Noen utbildningskommissioner mener dessuten klyngetilnærmingen er noe problematisk. Definisjonen av en klynge er ennå vag, og det er for tiden fagfelt som hører til i nesten alle klyngene, noe som gjør konseptet nesten ubrukelig.

Som helhet virker systemet med utbildningskommissioner og en styringsgruppe i utgangspunktet funksjonelt, men det er ennå mange problemer som må løses. En er at systemet er for spredt og komplekst, det er for mange aktører og prosjekter inkludert, selv om antall utbildningskommissioner ble redusert. Det er fristende også her å konkludere på følgende måte når det gjelder arbeidsmarkedsplanleggingen og prognosene; Det mangler en grundig oppfølging og evaluering av resultatet av disse øvelsene. Hva har man faktisk kommet fram til? Hva har man fătt til?

\subsection{Konklusjon}

Det ekspanderende systemet av utdannings- og arbeidsmarkedsframskrivinger og prognoser produserer i øyeblikket enorme mengder informasjon om forandringer, utviklingstrender og framtidige behov i arbeidslivet. Utfordringene vi har med en økende avgang fra arbeidslivet, lavere årskull i utdanning og en minskende arbeidsstyrke, gjør at behovet for å få til kvalitet, treffsikkerhet og presisjon på denne informasjonen blir stadig 
viktigere. Det desentraliserte systemet som man har nå, må få mer systematisk planlegging og en mer helhetlig nasjonal strategi, noe som også ble påpek i myndighetenes program for sysselsetting, entreprenørskap og arbeidsliv. ${ }^{3}$ Det er fortsatt forskjellige måter å forstå hva en prognose er, og spesielt på lokalt nivå har forskjellige aktører og organisasjoner, med deres forskjellige interesser, en viktig rolle i arbeidet med å utvikle prognoser. En viktig del av arbeidet med framtidige kvalifikasjonsscenariene er foretatt i midlertidige prosjekter, og dermed ikke stabilt. Koblingen mellom resultatene av prognosene og politikkutformingen er svak eller vanskelig å se. Til slutt, oppfølging og vurdering av prognosene og deres resultat er også svakt utviklet.

${ }^{3} \mathrm{http}: / /$ www.valtioneuv osto.fi/toiminta/politiikkaohjelmat/tyo-yrittaminen-tyoelama/ohjelmansisaeltoe/en.pdf. 



\title{
2. De islandske erhvervsuddannelser
}

\author{
Gestur Guðmundsson, \\ Islands Universitet
}

Denne korte redegørelse for de islandske erhvervsuddannelser lægger vægt på at belyse blandingsforholdet mellem stats-, markeds- og partsstyring $\mathrm{i}$ planlægning og administration af erhvervsuddannelserne og hvordan hensyn bliver taget til aktuelle og fremtidige behov på arbejdsmarkedet, både arbejdslivets behov og elevernes ønsker. Særlig vægt vil også blive lagt på indflydelse fra internationalt samarbejde. Disse hovedpunkter, samt mere detaljerede problemstillinger, er fælles for indfaldsvinklen i alle de nordiske landerapporter, men det er også nødvendigt at redegøre for en række træk, sem sætter særlig stærk præg på de islandske erhvervsuddannelser, herunder visse forudsætninger i historie, langtidsudvikling og svingninger $\mathrm{i}$ $\varnothing$ konomi og erhvervsliv. Det er også vigtigt at vie hensyn til erhvervsuddannelsernes placering og omfang indenfor de samlede ungdomsuddannelser, deres relation til videregående uddannelser, samt den aldersmæssige rekruttering til erhvervsuddannelserne.

I Island har bekymringer angående erhvervsuddannelsernes tilpasning til aktuelle og fremtidige komptencer gennemgående været dobbelte: for at uddannelser og virksomheder ikke er tilstrækkelig opmærksomme på udvikling i teknologi og kompetencer, og for en manglende elevtilgang til erhvervsrettede uddannelser. Fremstillingen her skal ses i lys af denne dobbelte problemstilling. 


\subsection{Skiftende vægt mellem parts-, stats- og markedsstyring- ungdomsuddannelserne samles}

Fra sit ophav i 1800-tallet har faguddannelserne udgjort tyngdepunktet i de islandske erhvervsuddannelser. De blev formet mens Island var en del af det danske rige og denne oprindelse er stadigvæk med til at præge deres udvikling.

Frem til 1949/1955 havde mestrenes sammenslutninger ansvar for såvel det faglige indhold i faguddannelserne som for de tekniske skoler, der kun tog sig af de boglige fag. Med lov fra 1949 blev Rådet for faguddannelser stiftet, med repræsentanter for mestre og svende, og det fik som hovedopgave at føre tilsyn med arbejdspladsoplæringen via egne fuldmægtige i enkelte distrikter. Med lov fra 1955 påtog staten sig ansvaret for de tekniske skoler. Den diskurs blev efterhånden dominerende at partsstyringen ikke var i stand til at tilpasse faguddannelser til den accelerende teknologiske udvikling.

Form og indhold i de tekniske uddannelser havde stadig sine rødder i de danske uddannelser, men blev tilpasset til islandske forhold. ${ }^{4}$ Der var tale om mesterlære og begrænset skolegang, mest i almene fag. I 1960erne blev Island revet med i den internationale bølge af uddannelsesreformer, og på erhvervsskoleområdet anbefalede norske OECD-eksperter (Kvikstad og Löken, 1963), at de tekniske skoler oprettede basisuddannelser indenfor de store fag, træ-, metal- og elektricitet. Disse blev etableret omkring 1970.

Under den voksende industrialisering fra 1930erne til 1950erne tog op til $20 \%$ af en ungdomsårgang faguddannelse, mens studentereksaminer var forbeholdt omkring $5 \%$. I 1960erne gik tilgangen til faguddannelserne tilbage og gymnasieuddannelserne overhalede dem i begyndelsen af 1970erne. I denne situation blev troen på tekniske uddannelser som human kapital blandet sammen med andre reformstrømninger, og i

\footnotetext{
${ }^{4}$ Et markant eksempel er udviklingen af byggefaget, hvor man i Island gik over til betonbyggeri i de første årtier af det 20. århundrede. Island ske mestre indsamlede viden fra forskellige lande og prøvede sig frem til løsninger som var brugbare under natur- og vejrforholdene i Island.
} 
begyndelsen af 1970erne fremlagde statslige udvalg forslag om en integreret ungdomsuddannelse, som ikke mindst skulle sidestille erhvervsuddannelser med alment boglige uddannelser og sikre tilstrækkelig tilgang til både erhvervsrettede ungdomsuddannelser og tekniske uddannelser på universitetsniveau.

I 1970erne og 1980erne blev de tekniske skoler og de almene gymnasier i vid udstrækning integreret og nye integrerede skoler opstod, ikke mindst i udkantsområderne. Indholdsmæssigt levede integrationen dog ikke op til de oprindelige idealer, uddannelsesretningerne foreblev adskilt og kun de boglige fag blev samordnet. I 1970erne så recepten mod tilgangskrisen ud til at virke, men i 1980erne var der igen stagnerende tilgang til erhvervsuddannelserne, mens tilgangen til almengymnasierne galopperede i begge årtier. I slutningen af 1960erne tog $10 \%$ af en ungdomsårgang studentereksamen, I slutningen af 1970erne var det $20 \%$ og $40 \%$ i slutningen af 1980 erne. Siden er den vokset til over $50 \%$, mens svendeproduktionen har ligget på under $15 \%$ af en årgang.

Trods integrationen af de forskellige ungdomsuddannelser $\mathrm{i}$ et system og $\mathrm{i}$ stigende grad under samme tag, foreblev ansvaret for det faglige indhold hos parternes fagråd. Da stagnation og tilbagegang i elevsøgning igen satte ind, fik denne ordning gerne skylden. Med en ny lov for ungdomsuddannelserne fra 1988 blev vægten på integration af ungdomsuddannelserne forstærket, og beslutningskompetencen om det faglige indhold blev overført til undervisningsministeriet. Rådet for faguddannelser blev rådgivende, bistået af fagudvalg for de enkelte fag. Pendulet tog altså et vigtigt ryk videre fra partsstyring til statsstyring (Gestur Guðmundsson, 1993).

I de kommende år blev der stiftet uddannelsesråd for erhvervsuddannelser uden for faguddannelserne, og med lov fra 1996 fik hele erhvervsuddannelseområdet en fælles ordning, med 12 brancheråd, alle med repræsentanter for arbejdsgivere og lønmodtagere på det pågældende område, samt fra ministeriet. Hensigten var at styrke erhvervslivets indflydelse; rådene var kun rådgivende men var tiltænkt omfattende opgaver: at fastlægge krav til kundskab og kompetence i de enkelte fag og stille forslag om opbygning af studielinjer, studieplaner, regler om arbejdspladsoplæring, eksamen og flere aspekter af uddannelserne.

I den næste lovgivning på ungdomsskoleområdet, i 2008, blev der ændret på kompetencefordelingen mellem ministerium, arbejdsmarkedets parter og 
skolerne. Brancherådenes virkefelt blev omdefineret til overordnet fastlæggelse af krav til kompetencer og kundskab (learning outcomes) og til opsyn med andre aspekter, som fastlæggelse af studieplaner, men udformningen af disse blev overladt til skolerne. Pendulet tog altså et ryk tilbage mod partsstyring, samtidig med at statsindflydelsen blev decentraliseret.

\subsection{Erhvervsuddannelserne i ungdomsskole, mesterlære og praktik i 00’erne}

Faguddannelserne udgør stadigvæk tyngdepunktet i erhvervsuddannelserne, mens hvad angår andre erhvervsuddannelser kan man tale om en udskiftning. Handels-, sygeplejer-, lærer- og pædagoguddannelserne i Island udviklede sig alle i perioden 1970-2000 fra specialskoler til universitetsuddannelser. Inden for ungdomsuddannelserne har man oprettet flere kortvarige erhvervsuddannelser, mange af disse er enten forsvundet eller blevet opslugt af almengymnasiet, men efterhånden har dog blandt andet en IT uddannelse, sundhedshjælperuddannelsen og socialhjælperuddannelsen overlevet, og flere uddannelser, ikke mindst indenfor turismesektoren, kombinerer studentereksamen og en erhvervsretning.

Erhvervsuddannelserne, især de tradtionelle faguddannelser, er overvejende mandefag, og Island har modsat andre nordiske lande ikke oprettet en faguddannelse indenfor Handel og Kontor eller inden for storindustrien. 
Tabel 1: Afsluttede studie- eller erhvervskompetencegivende eksaminer indenfor ungdomsskoleområdet 1995/96-2008/09

\begin{tabular}{|c|c|c|c|c|c|c|c|c|c|c|}
\hline & 99-00 & $00-01$ & $01-02$ & $02-03$ & 03-04 & 04-05 & $05-06$ & $06-07$ & $07-08$ & 08-09 \\
\hline $\begin{array}{l}\text { Erhv.eks } \\
\text { m. job- } \\
\text { komp }\end{array}$ & 613 & 600 & 619 & 663 & 727 & 710 & 701 & 731 & 884 & 674 \\
\hline $\begin{array}{l}\text { Svende- } \\
\text { prøver }\end{array}$ & 537 & 581 & 590 & 565 & 508 & 597 & 609 & 664 & 678 & 736 \\
\hline $\begin{array}{l}\text { Erhvervs- } \\
\text { stud.eks }\end{array}$ & 58 & 56 & 106 & 207 & 340 & 296 & 320 & 347 & 404 & 543 \\
\hline $\begin{array}{l}\text { Gen. } \\
\text { Studeks. }\end{array}$ & 2.128 & 2.102 & 2.137 & 2.360 & 2.195 & 2.147 & 2.148 & 2.230 & 2.420 & 2.495 \\
\hline
\end{tabular}

Kilde: Islands statistik

Tabellen viser, at en langsom vækst i den generelle studentereksamen har efterfulgt den eksplosive vækst som var sket fra slutningen af 1960erne og tyve år frem. Antallet svendeprøver viser derimod en stagnerende stabilitet ${ }^{5}$ og samme gælder for andre uddannelser som giver arbejdsmarkedskompetence. Den store vækst sker i det relativt nye fænomen, erhvervsstudentereksamen, som mestendels er en mellemlanding for unge, som har afsluttet en erhvervskompetencegivende uddannelse, men ønsker at gå videre til universiteterne.

Erhvervsuddannelserne er ikke blot mindre end den almene uddannelse til studentereksamen, men fylder endnu mindre i diskussionerne og i befolkningens bevidsthed. Det er dokumenteret, at elever, som skal til at begynde på ungdomsuddannelser, har begrænset viden om erhvervsuddannelser og som regel ret negativ holdning over for dem (Iðunn Kjartansdóttir, 2008). Når forskere, lærere og samfundsdebattører taler i generelle vendinger om ungdomsuddannelserne, taler de som regel kun om den boglige uddannelse rettet mod studentereksamen. I diskursen er erhvervsuddannelserne lillebror, og det mangfold af kortere udddannelses-

\footnotetext{
${ }^{5}$ Faktisk har antallet svendeprøver svinget mellem 500 og 850 i hvertfald siden 1980 og sand synligvis siden slutningen af 1950erne, og udsvingningerne skyldes i høj grad konjunktursvingninger (se senere), således at der på længere sigt er en svagt faldende andel af årgangene som tager svendeprøve, fra omkring 18 \% af årgang i 1980 (Gudmundsson, 1997) til omkring 14 \% i de senere år.
} 
forløb (ikke medtaget i tabellen overfor), som er rettet mod frafaldstruede elever, bliver i debatten nærmest forbigået som Evas beskidte børn.

Fra omkring 1970 og frem til 1990erne ændrede de islandske faguddannelser sig fra mesterlære til en blanding af skoleuddannelse og mesterlære/praktikpladsforløb. Partindflydelsen på denne udvikling fremgår tydeligt af det forhold, at de enkelte fag har kunnet vælge meget forskellige blandingsforhold. Levnedsmiddelområdet er det fagområde, som mest konsekvent har bibeholdt princippet om, at størstedelen af uddannelsen skal foregå på kontrakt hos mester. Her er tre semestres skoleuddannelse lagt $i$ en sandwich mellem mesterlære med kontrakt i fem semestre ialt. Den anden yderpunkt findes i elektrikerfagene, hvor skoleuddannelsen efterhånden fylder 6 eller 7 semestre, suppleret med 1-2 semestres praktik. Indenfor metalområdet er hovedreglen 6 semestre i skole. Indenfor automekanikerområdet og Byggeog anlægsområdet er eleven 4 eller 5 semestre på skole. Indenfor typografområdet er skolegangen 4 semestre. Kravet om lærlingekontrakt som en adgangsbetingelse er efterhånden blevet frafaldet i stadig flere faguddannelser, „nøglehullet“ ind til faget er nu sjældnest en lærlingekontrakt, men primært at komme ind på og bestå 4-7 semestres skoleuddannelse og kun sekundært at finde lærlingekontrakt eller praktikplads. Den samlede læretid er som regel 4 år, dog er nogle fag kun 3 eller $3 \frac{1}{2} 2$ år lange og på en enkelt linje, maskinmesteruddannelsen, tager det 5 år at opnå fulde rettigheder.

De forskellige blandingsformer mellem skoleuddannelse og mesterlære/ praktik har dog til fælles, at studieplanerne i alle fag lægger vægt på bredde og giver kun plads til begrænsede specialiseringer i studieforløbene.

Denne beskrivelse af erhvervsuddannelserne går ud fra en ideel elev, som fuldfører sin uddannelse i et ryk og uden pauser, studieskift og frafald. Som vi vil se senere er sådanne idealelever måske normen, men dog et mindretal. 


\subsection{Lovgivning og institutioner i lyset af hensynet til eksisterende og fremtidige krav på arbejdsmarkedet}

Uden særlig forskning eller systematisk vidensindsamling er det den generelle vurdering i Island, at omstilling og nyskabelser i erhvervslivet sjælden forhindres af manglende kompetencer eller omstillingsvilje. Islands arbejdskraft har historisk været omstillingsparat, villig til at flytte geografisk og mellem arbejdsområder. Det er også den generelle opfattelse at gennemsigtigheden i det lille islandske samfund har bevirket at man hurtigt har set problemer komme og haft nemt ved at overskue tiltag over for problemer (Haukur Harðarson og Fjóla María Lárusdóttir, 2010).

1960 ernes og 1970ernes diskurs om hastig teknologisk udvikling og medfølgende behov for drastiske tiltag for at fremskaffe de nødvendige reformer indebar elementer af prognoser og planøkonomi (Um nýskipan verk- og tæknimenntunar á Íslandi, 1971), men den sejrende tankegang var snarere, at enkelte aktører ville reagere hensigtsmæssigt og at uddannelsessystemets opgave ikke mindst skulle være at imødekomme "den sociale efterspørgsel” efter uddannelse (Jónas H. Haralz, 1965). Trods enkelte forsøg på storstilede fremtidsprognoser (Jón Torfi Jónasson, 1990), er vægten i den praktiske politik snarere blevet lagt på at opstille institutioner, samråd og informationskanaler, som sørger for en tilstrømning af informationer og kundskab for at sikre at uddannelserne tilgodeser både aktuelle og fremtidige behov.

Debat og tiltag til at sikre tilstrækkelig tilstrømning til erhvervsuddannelser har igennem flere årtier været kendetegnet af to modstridende antagelser. Den ene er baseret på den vurdering, at høje kompetenceniveauer i stigende grad er nødvendige og at de potentielle elever er klare over det. Denne antagelse fører til en bogliggørelse og vægt på tekniske kundskaber på højt niveau. Den anden går ud på, at erhvervsuddannelser er afhængige af at få fat i unge, som ikke er tiltrukket af boglige uddannelser. Den fører til at man i begyndelsen af uddannelsen lægger vægt på praktiske færdigheder og regner med dermed at kunne motivere eleverne for de mere boglige krav, som de så møder senere.

Den voksende statsstyring af erhvervsuddannelserne i 1970erne og 1980erne bestod dels i en modernisering af de boglige fag og en samordning 
med de almengymnasiale uddannelser med henblik på fleksibilitet. Bag den lå dog også en tvivl om, at partsorganisationerne var i stand til at rette uddannelserne mod fremtidige krav på arbejdsmarkedet. Parterne var på den anden side skeptiske over for statsliggørelsen, og således konkluderede en af arbejdgiverne hovedeksperter på erhvervsuddannelser i sin kandidatafhandling 2005, at erhvervsuddannelserne havde været indholdsmæssigt mere eller mindre uændrede i 10-15 år og ret upåvirket af udviklingen på arbejdsmarkedet (Ingi Bogi Bogason, 2005).

I mellemtiden havde der fra sen-1980erne vokset en tro på, at udbygning af efteruddannelser og medfølgende kompetenceudvikling blandt såvel lærere som kursister kunne blive det columbusæg, som sikrede en stadig tilstrømning af ny viden, kompetencer og forståelse af den globale erhvervs- og kompetenceudvikling. På de faglærtes område, og senere også de ufaglærtes, afsatte overenskomsterne en fast procentdel af lønnen som bidrag til efteruddannelse. Den efterfølgende vækst i fagenes efteruddannelsescentre var måske det vigtigste argument bag styrkelsen og samordningen af branche- og fagråd i 1996, og i de efterfølgende år blev disse yderligere styrket, og desuden samlede man kræfterne og har således nu tre større centre. I en nyere evaluering udtaler uddannelsecentrene og brancherådene samstemmigt, at den voksende efteruddannelse har medført en forøget sensitivitet overfor ændrede og kommende kompetencekrav, nationalt og internationalt, samt at disse erfaringer formidles til de tekniske skoler (Elín Thorarensen \& María Kristín Gylfadóttir, 2010). Disse og andre evalueringer er dog stærkt prægede af partsinteresser, og der er klart behov for uafhængig kvalificeret forskning, som i de senere år kun har fundet sted i en række kandidatafhandlinger (se Helen Williamsdottir Gray (2009), for en oversigt).

Med Loven om Ungdomsuddannelser fra 2008 blev brancherådenes position styrket og de indeholder nu repræsentanter fra skolesiden også, samtidig med at det er nu blevet skolernes opgave at udvikle studielinier og læseplaner, som senere bliver behandlet af brancheråd og godkendt af ministeriet.

Brancherådene har endvidere fået et koordinerende udvalg for rådene, som er sammensat af formændene for de enkelte råd og repræsentation fra ministeriet, med henblik på at sikre fodslag mellem rådene og at de alle deltager aktivt i udviklingen. 
Den tredje ændring går ud på at stifte en „arbejdspladsfond“ („vinnustaðasjóður") med bidrag fra stat og arbejdsgivere, for at betale til arbejdspladser som optager lærlinge og praktikanter. Siden maj 2011 har et udvalg forberedt et lovforslag, regeringen har erklæret at den har reserveret bevillinger til fonden i de første fire år og en forsøgsordning blev igangsat i september 2011.

Evalueringen af disse ændringer (Elín Thorarensen \& María Kristín Gylfadóttir, 2010) viser parternes syn på kanalisering af nutidige og fremtidige krav ind $\mathrm{i}$ udformningen af erhvervsuddannelserne. Arbejdsgiverne ser deres rolle som dobbelt: at sikre at deres syn på aktuelle og fremtidige udfordringer finder vej ind til uddannelsen, og at sikre at arbejdspladserne opfylder de krav som stilles til praktik og lærlingekontrakter. Fagbevægelsen lægger særlig vægt på at udpege områder, hvor der er behov for kompetenceudvikling og hvor man kan forvente vækst. Skoler og uddannelsescentre ønsker at blive anerkendt som stedet, hvor parternes krav mødes og omformes til studielinjer, læreplaner og undervisningsmetoder, som både tiltrækker elever og forbereder dem på at opfylde arbejdsmarkedets krav i nær og fjern fremtid.

En vigtig kanal for tilførsel af viden om nye og kommende kompetencebehov er adgangen til europæiske samarbejdsorganer, især CEDEFOP og Leonardo. Siden 1990erne har Islands Universitets Research Liaison Office taget hånd om disse forbindelser. Kontoret har formidlet deltagelse i samarbejdsprojekter og i opkvalificerende kurser for lærere og partsrepræsentanter, det løbende har produceret information om de islandske erhvervsuddannelser, i de senere år i form af årlige rapporter (http://refernet.is/page/utgafur). I sommeren 2011 indledte Island samarbejde med CEDEFOP om at lave prognoser om kompetencebehov i det islandske arbejdsliv.

\subsection{Frafald og alderssammensætning}

Alle de nordiske lande har i omkring 20 år haft som målsætning at alle (dvs. $95 \%$ ) skal få en ungdomsuddannelse. I realiteternes verden er det kun Finnerne som har fået fuldførelsestallene over 80 \% men målsætningen bliver dog gentaget af enhver ny regering. 
Frafald bliver defineret på mange forskellige måder. De førende islandske forskere på området, Kristjana Stella Blöndal og Jón Torfi Jónasson (2010) har valgt at sætte et skel ved 24-års alderen. De har analyseret tre årgange, 1969-1975 og 1982-årgangene, og har fundet ud af at ved 24 års alderen havde $56 \%, 57 \%$, og $62 \%$ af årgangene ikke fuldført en ungdomsuddannelse. Altså $40 \%$ frafald, eller $35 \%$ hvis man ser bort fra de $5 \%$ som ikke er startet på en ungdomsuddannelse. Disse tal er bygget på registerdata, men forskerne har i forlængelsen foretaget større survey-undersøgelser for at finde ud af grunde til frafald og muligheder for at modarbejde det. Disse analyser viser at push- og pull-faktorer hænger tæt sammen, således at de frafaldne unge i næsten lige stort omfang angiver, at de ikke fandt ungdomsuddannelserne interessante, og at de blev tiltrukket af gode jobmuligheder.

Livet slutter dog ikke ved 24-års alderen, og her er det interessant at inddrage yderligere data. Europæiske datasæt om uddannelsesniveauet hos hele befolkningen, opdelt på alderskategorier viser at $80 \%$ islandske kvinder i alderen 30-34 havde fuldført en ungdomsuddannelse og at $80 \%$ af mænd i alderen 40-44 havde også gjort det. (Kristjana Stella Blöndal og Jón Torfi Jónasson, 2010) Hvilket vil sige at i det lange løb er frafaldet „kun“ på $20 \%$. Disse data styrkes og nuanceres af data om alderen ved fuldførelse af ungdomsuddannelse. 
Tabel 2: Antal svendeprøver, erhvervsstudenter og alm. Studenter 2000-2009 og deres fordeling på aldergrupperne 19-24 og 25+

\begin{tabular}{lrrrrrrrrr}
\hline & $\mathbf{2 0 0 0 - 1}$ & $\mathbf{2 0 0 1 - 2}$ & $\mathbf{2 0 0 2 - 3}$ & $\mathbf{2 0 0 3 - 4}$ & $\mathbf{2 0 0 4 - 5}$ & $\mathbf{2 0 0 5 - 6}$ & $\mathbf{2 0 0 6 - 7}$ & $\mathbf{2 0 0 7 - 8}$ & $\mathbf{2 0 0 8 - 9}$ \\
\hline Svendeprøve/ialt & 581 & 590 & 565 & 508 & 597 & 609 & 664 & 678 & 736 \\
$19-24$ & 263 & 278 & 269 & 221 & 269 & 250 & 293 & 286 & 327 \\
$25+$ & 318 & 312 & 296 & 287 & 328 & 359 & 371 & 392 & 409 \\
Andre erhverv/ialt & 600 & 619 & 663 & 727 & 770 & 701 & 731 & 884 & 674 \\
$19-24$ & 468 & 473 & 476 & 482 & 462 & 437 & 454 & 496 & 399 \\
$25+$ & 132 & 146 & 187 & 245 & 248 & 264 & 277 & 388 & 275 \\
Erhvervsstud. /ialt & 56 & 106 & 207 & 340 & 296 & 320 & 347 & 404 & 543 \\
$19-24$ & 30 & 52 & 121 & 212 & 179 & 188 & 171 & 184 & 245 \\
$25+$ & 26 & 54 & 86 & 128 & 117 & 132 & 176 & 220 & 298 \\
Alm student/ialt & 2.102 & 2.137 & 2.360 & 2.195 & 2.147 & 2.148 & 2.230 & 2.420 & 2.495 \\
$19-24$ & 1.969 & 1.981 & 2.200 & 2.043 & 1.943 & 1.948 & 2.033 & 2.225 & 2.303 \\
$25+$ & 133 & 156 & 160 & 152 & 204 & 200 & 197 & 195 & 192 \\
\hline
\end{tabular}

Kilde: Islands statistik. „Andre erhverv“ henviser til erhvervseksaminer, andre end svendeprøver, som giver jobkompetence.

Det fremgår af tabel 2 at siden 2000 har 6-9 \% af dem, som tager almindelig studentereksamen, været 25 år og ældre. Derimod har omkring $55 \%$ af dem som tager svendeprøve, tæt på $40 \%$ af dem, som færdiggør anden erhvervsuddannelse, og over $50 \%$ af den voksende flok af erhvervsstudenter været 25 år og ældre. Som nævnt har formodentlig størstedelen af erhvervsstudenterne taget en af de to andre eksaminer før, men samlet svarer antallet af folk over 25, som har færdiggjort mindst en af disse eksaminer i de seneste år, til 15-20\% af en ungdomsårgang. Tilgangen af voksne til disse eksaminer er altså hovedforklaringen til, at andelen af folk med gennemført ungdomsuddannelse vokser fra $62 \%$ ved 24 år til næsten $80 \%$ i alderen 35-40.

En del af forklaringen på det voksende „ældre-boom“ i de islandske erhvervsuddannelsr er indførelsen af realkompetencevurdering, som efteruddannelsescentrene har stået for, primært med inspiration fra Danmark. 492 (svarende til mere end $10 \%$ af en årgang) personer gennemgik realkompetencevurdering i 2007-2008, i gennemsnit fik de vurderet kundskaber som svarer til mellem halvt og et års boglig 
ungdomsuddannelse, og en fjerdedel af dem, som blev vurderet i 2008, havde færdiggjort svendeprøve et år senere (Harðarson og Lárusdóttir, 2010).

\subsection{Misforhold mellem erhvervsudvikling og udvikling af uddannelser}

Den største satsning på erhvervsudvikling i Island i den nyere tid har været opførsler af storindustri og dermed af vandkraftværker. I den forbindelse diskuterede man at opstille en industriarbejderuddannelse, men det viste sig, at mindst to af de internationale koncerner, som driver storindustrien, ønskede at bevare uddannelsen som virksomhedsintern, og så var den sag ikke længere. Storindustri og internationale koncerner har længe været blandt de mest kontroversielle emner i islandsk politik

\subsubsection{Faghøjskoler?}

Et voksende antal på erhvervsuddannelserne forlænger deres uddannelse med elementer, som defineres på et højere niveau end ungdomsuddannelserne. I 2008-9 var der tale om 570 elever, hvoraf en tredjedel færdiggjorde en uddannelse som mester i sit fag men andre tog tilsvarende uddannelser uden for de traditionelle fag. Det forslag er blevet stillet, bl.a. af de udvalg som forberedte ændringerne af erhvervsuddannelserne i 2008 (Starfsnámsnefnd, 2006), at der etableres faghøjskole(r) for disse uddannelser, men foreløbig er det forslag lagt på is og disse uddannelser finder sted indenfor ungdomsuddannelserne.

\subsubsection{Effekter af krisen 2008-}

En af konsekvenserne af overophedningen af den islandske økonomi i begyndelsen af 2000-tallet var, at væksten i ungdomsuddannelserne, herunder den voksende tilbagevending af tidligere frafaldselever, ikke blev bremset. Krisen førte til nedskæringer i den offentlige sektor, og selv om ungdomsuddannelserne ikke var den hårdest ramte sektor, måtte de afvise flere hundrede ansøgere i 2009 og 2010. Unge under 18 og unge over 18 som har opfyldt minimumskrav for at komme videre nyder første prio- 
ritet, men taberne blev de forhenværende frafaldselever, som ønskede at komme tilbage.

Det indgår i dette billede, at pull-effekten i frafaldet er reduceret ganske væsentligt. Fra 2000-2008 faldt op til $20 \%$ af hver årgang fra i løbet af de første to år i ungdomsskolen 1 . år til deres 3. år, men efter krisens start i 2008 er denne andel halveret halveret. Det store spørgsmål er her om disse $10 \%$ af hver ungdomsårgangen, som yderligere fastholdes på ungdomsuddannelserne, faktisk består deres eksaminer og kommer videre, men sikre oplysninger herom foreligger ikke endnu.

Derfor blev indsatser mod ungdomsarbejdsløshed koblet stærkt sammen med uddannelsestiltag. Ved årsskiftet 2009/10 satte regeringen i gang omfattende indsatser mod ungdomsarbejdsløshed (Ungt fólk án atvinnu, 2009). Her blev det grundprincip fastlagt, at alle unge arbejdsløse indkaldes til interviews efter tre måneders arbejdsløshed og derefter anvises en aktiverings- og/eller uddannelsesindsats. En del af arbejdsløshedskassens midler (i Island er betalinger til forsikring mod arbejdsløshed lovpligtige og går til en central kasse) blev kanaliseret til at igangsætte indsatser, der som regel består af en blanding af uddannelse og praktikpladser. Nogle af disse tiltag er nye, men man har også inddraget både ungdomsuddannelserne og efteruddannelsen, og tanken er ikke mindst, at man vil bruge disse indsatser til at udvikle studielinjer og arbejdsmetoder, som kan fastholde den frafaldstruede del af ungdommen på ungdomsuddannelserne. Disse indsatser blev intensiveret med en trepartsaftale som blev indgået i foråret 2011. Her blev det slået fast at ungdomsuddannelserne skal optage alle ansøgere, og omkring 1100 arbejdssøgende blev optaget ekstraordinært i efteråret 2011, heraf en stor del på erhvervsuddannelserne. Udgifter til disse nye indsatser er anslået til over 300 millioner DKK. I 2011 kommer de fra arbejdsløshedsmidler men fra og med 2012 fra statskassen. 


\subsection{Fremtidsudsigter}

Det er fremgået her, at megen „viden“ i de islandske erhvervsuddannelser består af formodninger og en tyrkertro på gennemsigtigheden i et lille system. Forhåbentlig vil dog en voksende forskning bidrage med mere håndfaste og dybere indsigter, så fremtidudsigter og alternative scenarier kan blive optillet på mere sikkert grundlag end her er muligt.

Fra 1960erne og frem til 1990erne var de islandske ungdomsuddannelser på den ene side kendetegnet af en eksplosiv vækst i de almengymnasiale uddannelser og på den anden side af det rekordstore frafald, hvor over en tredjedel af dem som begyndte på ungdomsuddannelserne faldt fra. Siden 1990erne er kendetegnene snarere tre, for det første en mere afdæmpet vækst i de almengymnasiale uddannelser, for det andet en vækst i erhvervsuddannelser uden for de traditionelle faguddannelser, og for det tredje er tidligere frafaldselever i voksende grad vendt tilbage til ungdomsuddannelserne. Fælles for begge perioder har været en talmæssig stagnation i de traditionelle faguddannelser, men der har været mere indholdmæssig fornyelse af dem i den anden periode. Fordelingen af magt og ansvar mellem parterne, ministeriet og skolerne er blevet justeret, og ikke mindst er både efteruddannelserne og de internationale forbindelser blevet styrket, i forventning om at det vil sikre en sensitivitet over for arbejdsmarkedets behov på kortere og længere.

Fremtidens behov kan ikke ret og slet forudsiges, de er også i høj grad afhængig af den industrielle og økonomiske politik, dog således, at udviklingen sjældent følger helt de udstukne mønstre. Således var udbygningen af erhvervsuddannelserne i 1970erne forbundet med en politik, der satsede på stærkt forøget industriel fremstilling, men endte snarere med at opfylde de voksende behov for arbejdskraft i byggebranchen og de forskellige servicesektorer. I den aktuelle debat i Island kan man tale om tre hovedscenarier for vækst i de kommende 10-20 år: For det første er der stærke fortalere for fornyede investeringer i storindustri og kraftværker som motoren i et nyt opsving. For det andet er det blevet fremhævet, at de små højteknologiske og software-producerende sektorer i Island er i de seneste år vokset så meget, også under krisen, at man bør forberede sig på at forsyne dem med titusindvis af medarbejdere i de kommende 10-20 år. For det tredje er der også en bred opbakning bag grøn vækst, både inden for høj- og lavteknologi men absolut 
ikke indenfor storindustri. De politiske tiltag vil sandsynligvis fortsætte med at tage hensyn til alle tre positioner, men styrkeforholdet er uvist.

I lyset af usikkerheden om de konkrete fremtidige kompetencebehov samt af den omstillingsparathed, som kendetegner arbejdsstyrken og økonomien, er der i Island først og fremmest en vilje blandt parterne og politikerne til at løfte det generelle kompetenceniveau ud fra et hensyn til beskæftigelsesmuligheder på kortere sigt, samt at styrke efteruddannelse og andre tiltag for at imødekomme fremtidens omstillingsbehov. Regeringen har opstillet det som en hovedmålsætning for de kommende 10 år at $90 \%$ af folk i den erhvervsaktive alder har opnået en erhvervs- eller studiekompetence, hvor der nu er tale om mindre end $70 \%$. På kortere sigt har industriorganisationerne vurderet, at deres behov for faguddannet arbejdskraft vil stige med $10 \%$ i det kommende år.

Erhvervsstudentereksaminerne er allerede blevet vigtige for fleksibiliteten, som en bro fra fag- og andre erhvervsuddannelser til universitetsuddannelserne. Først efter finanskrisen opstod det paradoksproblem at successen med at få 15-20\% af en årgang til at færdiggære en ungdomsuddannelse efter 25-årsalderen blev truet af begrænsninger af indtag på disse uddannelser. Problemet blev afværget med trepartsaftalen i 2011, men det må dog langt fra sikkert at Island vil løfte den store opgave under de økonomiske omstændigheder at give bedre uddannelse både til den nye generation og de ældre. Vil ungdoms-uddannelserne fastholde deres åbenhed over for de voksne uddannelsessøgende eller vil de i større grad blive dirigeret over i efteruddannelser? Der ligger mange den slags spørgsmål i den nuværende situation, i en økonomi, som længe har været mere udsat for svingninger end de andre nordiske økonomier og som nu står midt i et vadested i endnu højere grad end naboerne.

I Island har man opstillet en model for samspil mellem arbejdsmarkedets parter, ministerium, skoler, uddannelsescentre og impulser udefra, en model som har en knudepunkt i brancherådene og deres samarbejde med uddannelsescentre. Modellen fungerer ganske godt i enkelte brancher, men hvad med de andre brancher og, ikke mindst: Er den god nok til at fange og bearbejde udviklingstendenser og fremtidssignaler i økonomien generelt, såsom evt. vækstområder i kanten af eller udenfor de nuværende brancher? 



\section{Den svenska yrkesutbildningsmodellen}

Jonas Olofsson, Umeå Universitet og Alexandru Panican, Lunds Universitet

\subsection{Inledning}

Syftet med detta bidrag är att beskriva och diskutera de bärande beståndsdelarna i den svenska yrkesutbildningsmodellen och arbetslivets möjligheter att påverka utbildningarnas inriktning och dimensionering. $\mathrm{Vi}$ fokuserar på utbildning på grundläggande nivå, inom och utanför gymnasieskolan, och eftergymnasial yrkesutbildning utanför högskole- och universitetssektorn.

Det finns några särskilda karaktärsdrag som är värda att framhålla omedelbart. Den grundläggande yrkesutbildningen i Sverige skiljer sig från förhållandena i många andra länder genom att i huvudsak vara skolförlagd. Lärlingsutbildning är och har varit ett marginellt inslag inom gymnasieskolan. Samtidigt finns det politiska ambitioner att utveckla lärlingsutbildningen och en ny gymnasieskola med inslag av lärlingsutbildning ska etableras från hösten 2011. Ett annat förhållande är att utrymmet för vuxna att studera yrkesutbildningar på grundläggande nivå har varit begränsat. De möjligheter som har ebjudits har framför allt funnits inom ramen för arbetsmarknadsutbildningen. Ett tredje förhållande är att eftergymnasiala yrkesutbildningar i form av yrkeshögskoleutbildningar har fått en större betydelse. Det mesta tyder på att yrkeshögskoleutbildningen kommer att få en mer framskjuten ställning inom den svenska yrkesutbildningsmodellen framöver. 


\subsection{Gymnasial yrkesutbildning}

Gymnasieskolan omfattar 17 nationella program (13 yrkes- och 4 studieförberedande) och ett individuellt program för elever som inte är behöriga av att läsa på ett nationellt program. Samtliga program är 3-åriga och har en likformig utformning med gemensamma kärnämnen som kan leda fram till högskolebehörighet. ${ }^{6}$ De skolförlagda yrkesprogrammen skall omfatta minst 15 veckors arbetsplatsförlagd utbildning, dvs. en ganska liten arbetsplatsförlagd del, men uppföljningar visar att många skolor inte lever upp till detta krav.

Läsåret 2009/2010 studerade nästan 400000 elever i gymnasieskolan varav 162695 (41 procent) i yrkesförberedande program. Fristående eller enskilt organiserade skolor erbjuder i mindre utsträckning yrkesutbildning i förhållande till studieförberedande utbildning. ${ }^{7}$ Kostnaderna per elev i yrkesutbildning är genomgående högre och intresset för att erbjuda skolförlagd yrkesutbildning bland skolor med annan huvudman än kommunal har hittills varit begränsad.

Könsfördelningen är skev och följer traditionella linjer. Omvårdnadsprogrammet har t.ex. enbart 14 procent unga män. ${ }^{8}$ Fördelningen av elever mellan olika program är inte anpassad till arbetsmarknadens behov. Antalet elever på omvårdnadsprogrammet är långt mindre än efterfrågan; även industriprogrammet omfattar mindre elever än vad som efterfrågas. Däremot är antalet elever på estetiska programmet, medieprogrammet och naturbruksprogrammet större än vad som är motiverad ur arbetsmarknadssynpunkt. En kritik som har framförts i sammanhanget, bl. a. från olika forskare, är att dimensioneringen av utbildningsplatser mellan yrkesprogram inte regleras efter arbets-marknadens behov utan i allt för hög grad styrs av elevernas enskilda val (Olofsson \& Panican 2008, Olofsson 2010).

Sedan 2008 pågår en försöksverksamhet med gymnasial lärlingsutbildning. ${ }^{9}$ Hösten 2010 deltog cirka 8000 elever i denna verksamhet. Flertalet platser

${ }^{6}$ SOU 2008:27 Framtidsvägen - en reformerad gymnasieskola.

${ }^{7}$ Skolverket (2010) Skolor och elever i gymnasieskoan läsår 2009/10.

8 Skolverket (2010) Uppgifter på riksnivå, Tabell 4 A.

${ }^{9}$ SOU 2010:19 Lärling - en bro mellan skola och arbetsliv. 
återfinns inom fristående skolor. Baggium $\mathrm{AB}$ är dominerande med 2530 beviljade platser.10 Det har förekommit försöksverksamhet med gymnasial lärlingsutbildning tidigare, men utbildningsformen har aldrig fătt ett genomslag i Sverige. ${ }^{11}$

Varje skola som deltar i försöksverksamheten måste upprätta lärlingsråd med företrädare från skola, arbetsgivare och fackliga parter. Den pågående försöksverksamheten utreds inom ramen för en Nationell lärlingskommitté. ${ }^{12}$ Uppföljningarna ska vägleda utformningen av lärlingsutbildningen i den nya gymnasieskolan hösten 2011.

Det ges ett särskilt statsbidrag för varje lärlingsplats som uppgår till 25000 kronor. Pengarna går till skolorna som ska använda medlen för att bland annat finansiera utbildning av handledare på arbetsplatserna. I en uppföljning av det första försöksåret påtalas att skolorna inte använder anslaget för utbildning av handledare - åtminstone inte i tillräcklig utsträckning - och att lärlingsråden inte blir den instans som godkänner och kvalitetsgranskar lärlingsplatser, vilket egentligen är tänkt. Lärlingsråden ägnar sig inte åt att ta fram konkreta utbildningsplaner och har ingen central roll för uppföljningen av lärlingarnas utbildning på arbetsplatserna. ${ }^{13}$

\subsubsection{1 års gymnasiereform}

Hösten 2011 etableras en ny gymnasieskola med 12 yrkesprogram och 5 studieförberedande program. Yrkesutbildningarna ska erbjuda mer av färdigutbildning och underlätta för elever att snabbt erhålla stadigvarande sysselsättning inom sitt yrkesområde efter avslutade studier. Gymnasial lärlingsutbildning introduceras som ett alternativ till skolförlagda yrkesutbildningar.

\footnotetext{
10 Skolverket (2010) Beslut om 2010 års lärlingsplatser.

11 Olofsson, Jonas (2005) Svensk yrkesutbildning - vägval i internationell belysning. Se också Olofsson, Jonas \& Wadensjö, Eskil (2006) Lärlingsutbildning - ett återkommande bekymmer eller en oprövad möjlighet? Olofsson, Jonas (2007) "Utbildning - vägen till frälsning?" i Jonas Olofsson red.: Utbildningsvägen - vart leder den?; Olofsson, Jonas (2010) Krisen i skolan - utbildning i politiken och i praktiken. 12 Förordning (2007:1349) om försöksverksamhet med gymnasial lärlingsutbildning.

13 SOU 2009:85 Gymnasial lärlingsutbildning - hur blev det? Erfarenheter från första försöksåret.
} 


\subsection{Avtalsreglerad yrkesutbildning i arbetslivet}

Inom vissa branschområden förekommer färdigutbildning organiserad $\mathrm{i}$ vissa fall som lärlingsutbildning - ibland upp till ett par år - efter fullbordat gymnasialt yrkesutbildning. Utbildningen regleras via kollektivavtal - så kallade utbildningsavtal mellan arbetsmarknadens parter. Inom ett antal branscher finns det särskilda yrkesnämnder som ansvarar för utbildningen. Yrkesnämnderna erbjuder också fortbildning och vidareutbildning. Totalt finns det 25 yrkesnämnder, men dessa täcker i praktiken en mindre del av arbetsmarknaden. Det är en verksamhet som bedrivs utan formella band till eller med medfinansiering från statens sida.

En av de mest aktiva yrkesnämnderna är Byggnadsindustrins Yrkesnämnd (BYN) som reglerar färdigutbildningen för blivande byggnadsarbetare. Efter gymnasiet inleds en lärlingsanställning på en arbetsplats under cirka två års tid. Lärlingsutbildningen regleras i ett utbildningsavtal och dokumenteras i en särskild utbildningsbok som sedan ligger till grund för examinationen. Utbildningen leder fram till ett formellt yrkesbevis, en legitimation som ger innehavaren rätt att verka inom yrket. ${ }^{14}$

Under avtalslärlingsperioden utvecklas lönen och ackordersättningen enligt en bestämd trappa relaterad till antalet arbetade timmar. De tre senaste åren har antalet utfärdade yrkesbevis inom BYN växlat mellan 4000 och 6000 per år. ${ }^{15}$

Ett annat område med avtalsreglerad lärlingsutbildning är således Värme, Ventilation och Sanitets-branchen (VVS). VVS-branschens yrkesnämnd utfärdar ungefär 500 yrkesbevis per år. När en avtalslärling har klarat provet erhålles ett branschcertifikat som bevisar att man är certifierad VVS-montör, industrirörmontör, isoleringsplåtslagare eller VVS-isolerare. ${ }^{16}$

Elbranschen har också traditioner av avtalsreglerad lärlingsutbildning. En person som har fullbordat elprogrammet på gymnasieskolan tar anställning som avtalslärling på ett elföretag under ett års tid. Företaget ska vara godkänt av Elbranschens Centrala Yrkesnämnd. Lärlingstiden mots-

\footnotetext{
14 BYN, Byggnadsindustrins Yrkesnämnd (2010).

15 BYN, Byggnadsindustrins Yrkesnämnd. Årsrapport 2009 - BYN i hela Sverige.

16 VVS, Värme, Ventilation och Sanitets branschens yrkesnämnd - Branschprov (2010).
} 
varar ungefär 1600 timmar och ska leda fram till ett prov i enlighet med elsäkerhetsföreskrifterna. Godkänns provet utfärdas ett certifikat och avtalslärlingen får rätt att arbeta som elinstallatör. Det årliga antalet lärlingar innom elbranschen varierar mellan 1000 och 2000 per år. Variationerna är ganska betydande från ett år till ett annat. ${ }^{17}$

Finansieringen av yrkesnämndernas verksamhet skiljer sig mellan branscherna. Det förekommer kollektiv finansiering där avgifter tas ut av samtliga arbetsgivare som är berörda av utbildningsavtalet. Ett exempel är Transportsektorns Yrkesnämnd (TYA) som tar ut 0,2 procent av årslönesumman i berörda företag. TYA omfattar cirka 17000 företag och ungefär 100000 anställda. ${ }^{18}$

\subsubsection{Yrkesnämndernas inflytande}

Yrkesnämderna arbetar med valideringsfrågor och tar fram riktlinjer för bedömning av yrkeskompetens hos verksamma inom branscherna. Yrkesnämnderna påverkar också innehållet i de skolförlagda yrkesutbildningarna genom att utarbeta läromedel och utbildningsmaterial. Yrkesnämderna har kontakter med skolmyndigheterna liksom med enskilda gymnasieskolor samt erbjuder elevinformation och yrkesvägledning. Yrkesnämnderna vill påverka elevvolymerna inom respektive yrkesprogram för att dessa ska motsvara branschens behov. Yrkesnämnderna erhåller dessutom kurser för lärare.

\subsection{Yrkesinriktad vuxenutbildning (yrkesvux)}

Traditionellt har det inte förekommit särskilt mycket av yrkesutbildning inom ramen för den kommunala vuxenutbildningen (Komvux). Den kommunala vuxenutbildningen ska kopplas till förutsättningarna i arbetslivet

17 ECY, Elbranschens Centrala Yrkesnämnd - Statistik anställda/registrerade lärlingar 1995-2009 (2010).

18 TYA, Transportsektorns Yrkesnämnd (2010). 
och utbilda "för varierande arbetsuppgifter, medverka till arbetslivets förändring och bidra till full sysselsättning och därigenom främja utveckling och framsteg i samhället" (Lpf 94, 1 kap. 9 §). Utbildning erbjuds både på grundskole- och gymnasienivå. Antalet elever har emellertid minskat påtagligt på senare år. Går vi tillbaka tio år i tiden talar vi om mer än en halvering.

År 2009 fanns det drygt 80000 helårsstuderande inom kommunal vuxenutbildning. Andelen som går vidare direkt från ungdomsgymnasiet till kommunal vuxenutbildning uppgår till 15 procent. De flesta vill komplettera betygen från gymnasiet för att uppnå högskolebehörighet. En mindre del av eleverna läser på utbildningar som syftar till omedelebart inträde i arbetslivet. Den arbetslivsinriktade utbildning som har förekommit har framförallt varit orienterad mot vård- och omsorgssektorn. ${ }^{19}$ På senare år har intresset för att etablera yrkesutbildningar inom den kommunala vuxenutbildningen ökat markant.

Från hösten 2009 aviserade regeringen en ny satsning på yrkesutbildning inom ramen för Komvux, kallad yrkesvux. Denna satsning måste ses i perspektiv av den då aktuella finanskrisen och den höga arbetslösheten. Utbildningarna riktar sig till vuxenstuderande utan gymnasiekompetens och personer som behöver en ny yrkesutbildning. Vuxna med svag ställning på arbetsmarknaden ska generellt ha företräde vid urvalet av deltagare i yrkesvuxutbildningar. ${ }^{20}$ Utbildningarna ska motsvara dem som erbjuds inom ramen för gymnasieskolan. Hösten 2009 omfattande satsningen drygt 5000 platser. För åren 2010 och 2011 har regeringen anslagit medel motsvarande 10000 studieplatser årligen. Intresset är störst för omvårdnadsutbildningar, som motsvarar ungefär 30 procent av platserna. Därefter är intresset stort för industriorienterade och fordonsinriktade utbildningar.

Det finns inga formella krav på arbetsplatsförlagd utbildning inom yrkesvux. Det är upp till utbildningssamordnaren att besluta om arbets-

\footnotetext{
${ }^{19}$ Skolverket PM - Elever och studieresultat i komvux kalenderår 2009.

20 Betänkande 2009/10:UbU11 Vuxenutbildning.
} 
platsförlagd inslag i utbildningen. ${ }^{21}$ Komvux finansieras av kommunerna medan yrkesvux av staten.

Regeringens strävar också efter att det ska etableras mer av lärlingsutbildning och arbetsplatsförlagda utbildningsmoment inom ramen för Komvux. ${ }^{22} \mathrm{Ett}$ uttalat mål är att det ska skapas 5900 lärlingsplatser med anknytning till Komvux. ${ }^{23}$

\subsubsection{Arbetslivets inflytande}

De arbetsplatsförlagda utbildningarna på Komvux ska genomföras i form av entreprenad, bl. a. hos branschföretag. Detta förekommer idag, men man vill utveckla denna typ av samverkan i högre utsträckning framöver. Detta kan vara ett uttryck för intentionen att stärka arbetslivets inflytande över inriktningarna på de yrkesorienterade utbildningarna på Komvux. ${ }^{24}$

Enligt bestämmelserna för statsbidragen till yrkesvuxutbildningar ska kommunen planera utbildningen i samverkan med arbetsförmedlingen och lokalt näringsliv. ${ }^{25}$ Kommunen ska dokumentera behovet av de kvalifikationer som utbildningen syftar till, vilket innebär att man ska påvisa efterfrågan på arbetskraft för de utbildningar som erbjuds. Bestämmelserna är allmänt formulerade. Det tydliggörs inte hur samverkan mellan utbildningsanordnaren och arbetslivet ska utformas i praktiken. En enkätundersökning som genomfördes av Skolverket, ansvarig myndighet gällande yrkesvuxsatsningen, bekräftar att samverkan inte fungerar tillfredsställande. ${ }^{26}$ I många kommuner sker inget utbyte med arbetslivet $\mathrm{i}$ samband med att man ansöker om att organisera yrkesvuxutbildningar. Samtidigt måste man beakta att det rimligen tar viss tid att utveckla for-

\footnotetext{
${ }^{21}$ Skolverket (2010) Om Yrkesvux. Se också SFS 2009:43, Förordning om statsbidrag för yrkesinriktad gymnasial vuxenutbildning; SFS 2009:1077 Förordning om ändring i förordningen (2009:43) om statsbidrag för yrkesinriktad gymnasial vuxenutbildning.

22 Prop. 2008/09:199 Högre krav och kvalitet i den nya gymnasieskolan.

${ }^{23}$ Nyhetsbrev, Folkpartiet - Stora satsningar på utbildning (2010).

24 Prop. 2008/09:199 Högre krav och kvalitet i den nya gymnasieskolan.

25 SFS 2009:1077 Förordning om ändring i förordningen (2009:43) om statsbidrag för yrkesinriktad gymnasial vuxenutbildning.

${ }^{26}$ Skolverket (2009) Redovisning av regeringsuppdrag att förbereda och genomföra insatser inom yrkesvux.
} 
mer för effektiv samverkan. Yrkesutbildning inom Komvux är i huvudsak en ny företeelse.

\subsection{Yrkeshögskoleutbildning}

Eftergymnasiala yrkesutbildningar utanför högskolan har traditionellt inte haft stor omfattning. I mitten av 1990-talet startade en försöksverksamhet med kvalificerad yrkesutbildning - dvs. En utbildning på eftergymnasial nivå - som sedan blev reguljär i början 2000-talet. Verksamheten skulle rymmas inom en särskild myndighet för kvalificerad yrkesutbildning (KY-myndigheten). Dessa yrkesutbildningar skulle vara avancerade och anpassningsbara till arbetslivets behov. Det lokala och regionala arbetslivet skulle få ett betydande inflytande över utbildningsutbudet. En stor del av utbildningstiden skulle vara arbetsplatsförlagd. Vid sidan av kvalificerad yrkesutbildning fanns det inslag av yrkesutbildning på eftergymnasial nivå inom kommunal vuxenutbildning och som särskild lärlingsutbildning inom vissa hantverksyrken. Sedan 1 juli 2009 har samtliga eftergymnasiala yrkesutbildningar samlats i en särskild yrkeshögskolemyndighet, Myndigheten för yrkeshögskola (Yh-myndigheten). ${ }^{27}$

Yrkeshögskolan erbjuder följaktligen yrkesutbildningar på eftergymnasial nivå. Det finns två utbildningsformer och båda kombinerar skolförlagd utbildning med lärande i arbetslivet (LIA): yrkeshögskoleutbildning och kvalificerad yrkesutbildning. Från 2014 ska all utbildning inom yrkeshögskolan utgöras av så kallad yrkeshögskoleutbildning.

Yh-myndigheten som ansvarar för utbildningarna har ett nationellt ansvar för valideringsfrågor. I myndighetens uppdrag ingår att utveckla en nationell struktur för validering. Uppdraget ska genomföras i samverkan med andra statliga myndigheter, t.ex. Arbetsförmedlingen, Högskoleverket och Skolverket. ${ }^{28}$

${ }^{27}$ Fokus på jobb - kvalificerad yrkesutbildning för en ny tid (2009).

${ }^{28}$ Myndigheten för yrkeshögskolan - Om myndigheten för yrkeshögskolan (2010). 
År 2009 deltog drygt 40000 studerande i totalt 905 Ky- eller Yhutbildningar. Flertalet utbildningar motsvarade 2 till $2 \frac{1}{2}$ år, men många utbildningar var betydligt kortare än så. Det totala antalet helårsplatser uppgick till cirka 23000 ; andelen kvinnor var något högre än andelen män. Ekonomi, administration och försäljning utgjorde det största utbildningsområdet (23 procent) följt av Teknik och tillverkning (21 procent), Hälso- och sjukvård samt socialt arbete (11 procent) och Data/IT (9 procent). Totalt fanns det 16 utbildningsområden och sammanlagt 255 olika utbildningsanordnare. Yh-myndigheten arrangerar inte själv någon utbildning utan beviljar ansökningar om utbildning från utbildningsanordnare och godkänner därmed att utbildningarna får betecknas som eftergymnasiala yrkeshögskoleutbildningar. ${ }^{29}$

Uppföljningarna visar att utbildningarna ger goda resultat i termer av sysselsättning efter avslutad yrkesutbildning. 8 av 10 som avslutade en kvalificerad yrkesutbildning under år 2008 hade arbete eller drev ett eget företag i juni 2009. Enbart en av tio arbetade inom helt andra områden än det som utbildningen var inriktad mot. ${ }^{30}$

\subsubsection{Arbetslivets inflytande}

I styrdokumenten för yrkeshögskolan betonas arbetslivets inflytande över utbildningarna mycket starkt. Utbildningarna ska "utvecklas och bedrivas i samverkan mellan arbetsliv och utbildningsanordnare" (Lag 2009:128 om yrkeshögskolan, 6 § pt 4). Minst en fjärdedel av utbildningstiden ska bestå av lärande i arbete på en arbetsplats. Utbildningsanordnare ska upprätta en ledningsgrupp med företrädare för de delar av arbetslivet som berörs av utbildningen. Yh-myndighetens fördelning av statsbidrag till utbildningsanordnare ska ske utifrån en bedömning av i vilken utsträckning utbildningen motsvarar "arbetslivets behov av kvalificerad arbetskraft eller medverkar till att utveckla eller bevara kvalificerat yrkeskunnande inom ett smalt yr-

\footnotetext{
${ }^{29}$ Myndigheten för yrkeshögskolan (2010a) Årsredovisning 1 juli - 31 december 2009.

${ }^{30}$ Myndigheten för yrkeshögskolan (2010b) Uppföljning av Ky-studerandes sysselsättning ett år efter examen. Se också Myndigheten för yrkeshögskolan (2010c) Utbildningsanalys 2010 - Myndigheten för yrkeshögskolans analys av arbetslivets efterfrågan på kompetens.
} 
kesområde som är av betydelse för individen och samhället" (Förordning 2009:130 om yrkeshögskolan, kap 5, 5§, pt 1).

Yh-myndigheten har ett arbetsmarknadsråd på nationell nivå med företrädare för Arbetsförmedlingen, Sveriges kommuner och landsting, Företagarna, Svenskt näringsliv samt de fackliga huvudoirganisationerna LO och TCO. Arbetsmarknadsrådet ska bistå med långsiktiga bedömningar av hur kvalifikationskraven och arbetskraftsbehoven utvecklas på arbetsmarknaden. Bedömningarna har betydelse för Yh-myndighetens fördelning av statsbidrag till olika utbildningar. ${ }^{31}$

Inför de årliga ansökningsomgångarna genomför Yh-myndigheten en analys av efterfrågan på kompetenser som yrkeshögskoleutbildningar förväntas leda till. Företrädare för branscherna och regionerna tillfrågas om deras uppskattning av arbetskraftsbehov och kompetensbehov under de närmsta åren. Bedömningarna sätts i relation till utbildningsanordnarnas ansökningar om att få starta utbildningar. I utbildningsanordnarnas ansökningar ska sambandet mellan innehållet i utbildningen och det regionala arbetskraftsbehovet vara väl dokumenterat. ${ }^{32}$

\subsection{Arbetsmarknadsutbildning}

Arbetsmarknadsutbildningen har varit en avgörande del av den aktiva arbetsmarknadspolitiken i Sverige. Med arbetsmarknadsutbildning avses kvalificerad yrkesutbildning för arbetslösa för att underlätta matchning, rörlighet och strukturomvandlingen i ekonomin. Antalet deltagare i arbetsmarknadsutbildningen har varit omfattande oavsett konjunkturläge; syftet har varit att rusta individerna kompetens- och erfarenhetsmässigt så att deras möjligheter att få jobb ökar. ${ }^{33}$

\footnotetext{
31 Myndigheten för yrkeshögskolan (2010c) Utbildningsanalys 2010 - Myndigheten för yrkeshögskolans analys av arbetslivets efterfrågan på kompetens.

32 Ibid.

33 Olofsson, Jonas \& Wadensjö, Eskil (2009) Arbetsmarknadspolitik - förändrade förutsättningar och nya aktörer.
} 
Fram till 1990-talet bedrevs arbetsmarknadsutbildningen i arbetsmarknadsmyndighetens egen regi. Under 1990-talet bröts verksamheten ut. Idag upphandlas all arbetsmarknadsutbildning av externa utbildningsanordnare.

Ser man mer översiktligt på arbetsmarknadspolitiken kan det konstateras att arbetsmarknadsutbildningen har minskat kraftigt till förmån för den tidigare aktivitetsgarantin, numera jobb- och utvecklingsgarantin samt jobbgarantin för ungdomar. I samtliga fall kan man tala om insatser med mer av fokus på individuell handledning och ensidigt jobbsökande, mindre på långsiktig kompetensutveckling. ${ }^{34}$

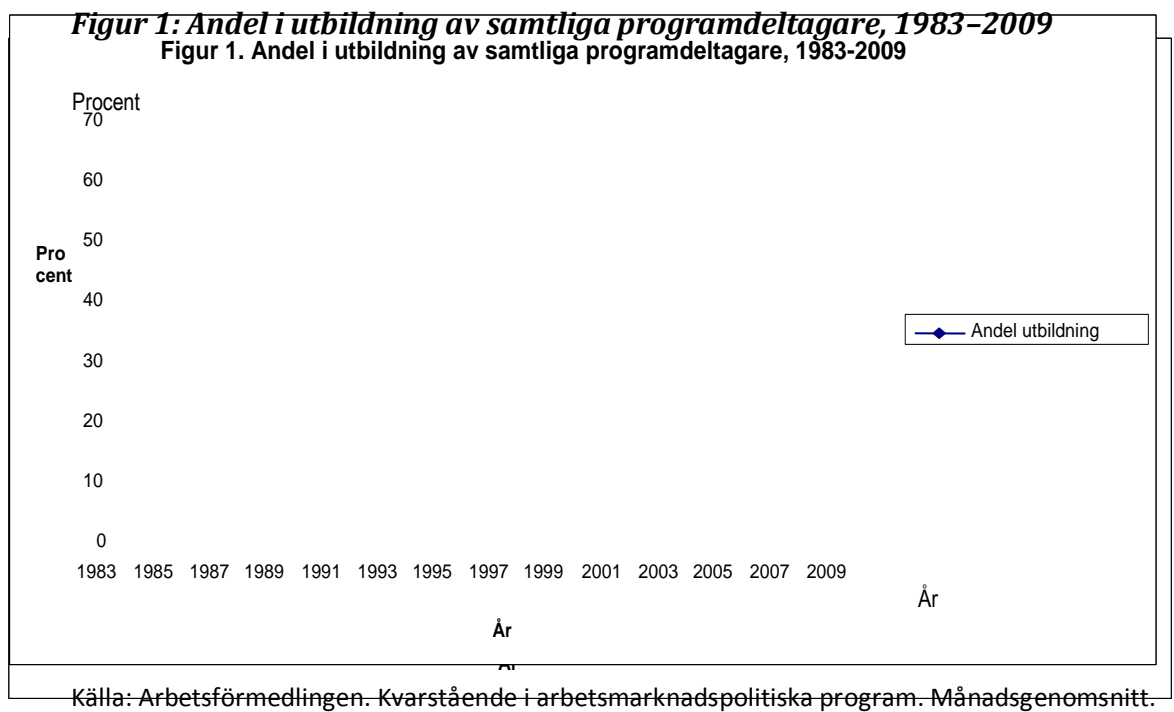

I Figur 1 illustreras en kraftig minskning av andelen deltagare i utbildning. Andelen har halverats sedan slutet av 1990-talet. Uppgifterna i figuren gör inte skillnad mellan deltagare i förberedande utbildning (kurser för att förbereda deltagarna för annan programverksamhet, t.ex. social träning) och yrkesinriktad arbetsmarknadsutbildning. Den yrkesinriktade arbetsmarknadsutbildningen har minskat mest sedan 1990-talet.

${ }^{34}$ Finanspolitiska rådets rapport (2010) Svensk finanspolitik. 
Inom arbetsmarknadspolitiska programverksamheten har garantiinsatser dominerade av jobbsökaraktiviteter fått ett allt större utrymme. Ett exempel är aktivitetsgarantin som tillkom år 2000 och som därefter har ersatts med jobb- och utvecklingsgarantin. Dessa är paraplybeteckningar för verksamheter inom en rad olika program. Utmärkande är den lokala styrningen av innehållet, frånvaron av en tydlig bortre tidsgräns och orienteringen mot personer med långa arbetslöshets- och inskrivningsperioder. Inskrivningstiden skulle motsvara två år för deltagande i aktivitetsgarantin. Inom jobb- och utvecklingsgarantin har denna tidsgräns sänkts till 300 arbetslöshetsdagar.

Flera program kan räknas till kategorin "förberedande" insatser och som särskilt vänder sig till utsatta grupper såsom förberedande utbildning, projekt med arbetsmarknadspolitisk anknytning, ungdomsinsatser (jobbgarantin) och tidigare datortek/aktivitetscenter. Programmen ska tillgodose förändrade behov på arbetsmarknaden. Det handlar om att tillgodose behov hos grupper som lätt fastnar i en perifer position och långvarigt bidragsberoende: ungdomar med svag utbildning, äldre som blir arbetslösa, utomnordiska invandrare och funktionshindrade. De risker som följer av långvarigt utanförskap möts med insatser för att motverka social exkludering. Problemet är att orienteringen mot dessa program har skett parallellt med att man i stort sett har avvecklat mer kvalificerade programinsatser. Arbetsmarknadspolitiken har fått en mer markant socialpolitisk karaktär.

Arbetsmarknadsutbildningen var en väsentlig del av den yrkesinriktade vuxenutbildningen och kompetensförsörjningen på arbetsmarknaden. Idag spelar arbetsmarknadsutbildningen en ytterst marginell roll samtidig som mycket talar för att matchningsproblemen på svensk arbetsmarknad ökar.

\subsubsection{Arbetslivets inflyttande}

Arbetsförmedlingen samverkar på olika sätt med arbetslivet och arbetsmarknadens parter. Det finns ett särskilt rådgivande organ på nationell nivå kallad partsrådet som består av myndighetens generaldirektör, representanter för arbetsgivare och fackliga företrädare. I riktlinjer för Arbetsförmedlingen framhålls betydelsen av samverkan med skolor och 
försäkringskassor på lokal nivå för att underlätta ungdomars och funktionshindrades arbetsmarknadsetablering. Några mer precisera riktlinjer för denna samverkan presenteras inte. ${ }^{35}$

Organisationen inom arbetsmarknadspolitiken förändrades för några år sedan. Tre myndigheter slogs samman till en arbetsmarknadspolitisk myndighet: Arbetsförmedlingen. Samrådsorgan mellan lokala arbetsförmedlingar och enskilda kommuner, så kallade arbetsförmedlingsnämnder, upplöstes. Varje kommun skulle ha en nämnd med en kommunföreträdare som ordförande och deltagare från arbetsmarknadsorganisationer som skulle dryfta frågor av gemensamt arbetsmarknadspolitiskt intresse. Nämnderna kritiserades, framför allt från kommunalt håll för att sakna reellt inflytande över arbetsförmedlingarnas verksamhet. Från arbetsförmedlingarnas sida fanns ett missnöje med att kommunernas inflytande blev för stort. Nämnderna har ersättas med ett lokalt samrådsorgan, lokala arbetsmarknadsråd med chefer för arbetsförmedlingens arbetsmarknadsområden som sammankallande. I råden ska det finnas företrädare för kommunen och myndigheter som försäkringskassan samt representanter för företag och fackliga organisationer. Syftet är att arbetsförmedlingen ska få bättre information om lokala arbetsmarknadsförhållanden och behovet av utbildad arbetskraft på olika områden. Mycket talar för att dessa samrådsorgan spelar en liten roll för arbetsförmedlingens programutformning och planeringsverksamhet. De lokala arbetsmarknadsråden har mest karaktären av informationsorgan. Samrådsorganen har inga möjligheter att fatta konkreta beslut om resursfrågor och verksamhetens inriktning. Ansvaret ligger ytterst på myndigheten.

\subsection{Avslutning}

Denna översikt avslöjar några grundläggande mönster som utmärker de svenska erfarenheterna. Det gäller de begränsade inslagen av arbetsplatsförlagd yrkesutbildning och det begränsade utrymmet för grundläggande

35 Förordningen (2007:1030) med instruktioner för Arbetsförmedlingen. 
yrkesutbildning för vuxna utanför arbetsmarknadspolitikens ram. Samtidigt visar översikten att modellen präglas av snabba förändringar. Yrkesutbildningarna i gymnasieskolan kommer att knytas närmare arbetslivets krav och en gymnasial lärlingsutbildning kommer att introduceras. Dessutom görs satsningar på yrkesutbildning inom ramen för den kommunala vuxenutbildningen samtidigt som nya typer av yrkeshögskoleutbildningar vinner större uppskattning. Mycket talar för att en översikt om den svenska yrkesutbildningsmodellen kan se annorlunda ut om några år.

Samtidigt är regleringen av arbetslivets inflytande över yrkesutbildningarna förmodligen nyckeln till framgång i reformsträvandena. Det sistnämnda manar till eftertanke eftersom utbytet skola-arbetsliv egentligen varit en akilleshäl i det svenska utbildningssystemet. Frågan är om man kommer att lyckas att skapa nya förutsättningar för arbetslivets medverkan i yrkesutbildningen. Tidigare försök har inte lyckats särskilt väl. Här handlar om att bryta ett historiskt mönster. 


\section{Det norske systemet}

Håkon Høst, NIFU Nordisk institutt for studier av innovasjon, forskning og utdanning

\subsection{Introduksjon}

Hvordan er forholdet mellom arbeidslivets behov for kompetanse og utformingen og dimensjoneringen av yrkesutdanningssystemet i Norge? På hvilken måte kan og blir arbeidslivets behov formidlet til utdanningssystemet? Og i hvor stor grad dreier det seg om å reprodusere dagens arbeidstokk kontra det å planlegge for fremtidige behov? For å kunne besvare disse spørsmålene er det nødvendig å beskrive det formelle yrkesutdanningssystemet vi har i Norge, hvilke mekanismer som er bygget opp for at det skal respondere på arbeidslivets behov, men også å diskutere i hvilket omfang dette systemet faktisk er i stand til å sørge for arbeidslivets tilgang på kompetent arbeidskraft.

Ut fra en kategorisering av yrkesutdanningssystemer som enten statlige, korporative eller markedsbaserte (Greinert 1999, Deissinger 2003), har Norge vært karakterisert som et blandingssystem Allmendinger (1989). Blandingsforholdet mellom disse styringsformene er i stadig endring og kommer til syne blant annet gjennom hvordan arbeidslivets behov for arbeidskraft og kompetanse formidles til og ivaretas av utdanningssystemet. Mens man i korporative systemer baserer seg på fremforhandlede arbeidstakerkategorier i form av fag som også avspeiles i utdanningssystemet, vil det i både statlige og markedsbaserte systemer ofte være en tendens til å ønske brede og mer generelle utdanningskategorier som siden spesialiseres i bedriftene.

Vi skal i dette kapitlet beskrive hvordan man i det norske systemet formidler mellom arbeidslivets behov og yrkesutdanningssystemets ut- 
forming og omfang. Først vil vi foreta en kort gjenomgang av de endringene som har gitt dagens system.

\subsection{Broket system}

I Norge har yrkesopplæringspolitikken siden 1970-tallet fulgt to ulike veier gjennom på den ene siden å basere seg på yrkesskoler og på den andre en lærlingordning. I tillegg har en rekke bransjer vært preget av at de rekrutterer ufaglærte for opplæring i jobben. Ulike typer yrkesskoler vokste fram fra slutten av det 19. århundret innenfor ulike bransjer og sektorer av arbeidslivet som håndverk, industri, handel, kontorarbeid, sjøfart, landbruk, husstell, helse og sosialarbeid (Grove og Michelsen 2005). Fagarbeid og lærlingordning som inngang til arbeidslivet var lenge et marginalt fenomen, men begynte å ekspandere fra rundt 1970 (Høst, Michelsen og Gitlesen 2008). Koplingene mellom yrkesskolene og lærlingordningen var varierende, men relativt løse i denne perioden. På noen områder tilbød yrkesskolene en fullverdig, skolebasert yrkesutdanning, mens de på andre områder tilbød teoretiske og praktiske kurs som kunne lede enten til en lærlingplass eller tjene som en mer generell yrkesutdanning som grunnlag for en jobb som ufaglært eller spesialarbeider i en bedrift. På den annen side var det ufaglærte ungdomsarbeidsmarkedet relativt stort (Høst og Michelsen 2010). Så sent som i 1975 hadde en tredjedel av ungdom i alderen 17-19 år sysselsetting som sin hovedaktivitet. ${ }^{36}$ En stor del av ungdomskullet entret dermed arbeidsmarkedet med få eller ingen yrkeskvalifikasjoner. Et magert tilbud av faglært arbeidskraft ga rom for en betydelig tilførsel av ufaglært ungdom i de fleste sektorer av arbeidslivet, deriblant både industri og servicearbeid, og en rekke bedrifts- eller bransjemessige praksiser for å møte rekrutterings- og opplæringsutfordringene ble reprodusert på det lokale nivået (Korsnes 1996). Det å bli ansatt som ufaglært kunne være starten på en bedriftsintern

36 Ungdomsundersøkelsen 1991, referert i Grøgaard (2006). 
karriere gjennom opplæring i jobben, men også en karriere mot fagarbeiderstatus eller annen yrkesutdanning.

\subsection{Reform 94-systemet}

Det yrkesutdanningssystemet vi har i Norge i dag, fikk i stor grad sin form gjennom Reform 94. Reformen dreide seg i stor grad om å standardisere og rasjonalisere de eksisterende utdanninger. De yrkesutdanningene som tradisjonelt var basert på yrkesskole kombinert med læretid dannet mønster for den hovedmodellen som ble valgt. Utgangspunktet var statens ønske om å skape et mer effektivt utdanningssystem på dette nivået, gjennom å etablere videregående opplæring som en del av et større, sammenhengende og sekvensielt system. Man ønsket å få bort såkalte horisontale vandringer, hvor ungdom gikk fra kurs til kurs på samme nivå uten å oppnå full kompetanse i noe, eller fra utdanning til arbeid og tilbake igjen til utdanning på samme nivå. I stedet ønsket man at hele ungdomskullet skulle de bevege seg fra den obligatoriske grunnskolen direkte inn i den videregående skolen, hvoretter de skulle velge vei; enten forberedelse til høyere utdanning gjennom studieforberedende utdanning eller gjennom yrkesutdanning og læretid til fagarbeiderstatus i arbeidslivet.

Ambisjonene var høye; ungdom skulle kunne velge mellom yrkesutdanninger rettet mot alle områder av arbeidslivet. I den andre enden skulle de ulike deler av arbeidslivet kunne rekruttere tilstrekkelig kompetent arbeidskraft blant ungdom utdannet gjennom dette systemet. Både ut fra effektivitetsbetraktninger og argumenter om rettferdig fordeling av utdanningsressurser ble systemet sterkt aldersstrukturert. Ordinær yrkesutdanning skulle nå primært være for ungdom mellom 16 og 19 år, mens voksne nå måtte stille bakerst i køen, ofte uten reell mulighet for plass. Målet var at all ungdom ved 20 års alderen skulle ha oppnådd et rimelig likeverdig utdanningsmessig utgangspunkt gjennom fullført videregående. Dette skulle legge grunnlaget for livslang læring i utdanningssamfunnet. Det nye systemet sto på denne måten i sterk kontrast til det tidligere videregående yrkesutdanningssystemet hvor over $40 \%$ av elevene var over 20 år, og hvor relasjonene mellom utdanning og arbeidslivet var svært ulike fra område til område. 
Reform 94 var primært en reform for å styrke utdanningssystemets indre logikk og effektivitet. Slik sett kan man si det handlet om å styrke statens rolle på bekostning av markedet gjennom å minimalisere avgang fra skolen til ufaglært arbeid. Gjennom sine offensive grep styrket også staten sin rolle på bekostning av den tradisjonelle korporative styringen av yrkesopplæringen. Reformens hovedgrep med å kople en toårig skoleutdanning direkte til en toårig læretid i bedrift, betinget imidlertid tett samarbeid med arbeidslivspartene. Det var slik sett nødvendig å få disse med på et forpliktende samarbeid om å bygge opp lærefag som omfattet arbeidstakerkategorier i alle sektorer av arbeidslivet, og dernest å mobilisere bedriftene til å stille til rådighet et tilstrekkelig antall læreplasser slik at elevene kunne fullføre sin opplæring i bedrift etter to år med skoleopplæring.

Reformens uomtvistelige suksess ligger i at man klarte å etablere koplinger mellom skole og læretid i bedrift gjennom at bedriftene innrettet seg etter reform-modellen og rekrutterte sine lærlinger hovedsakelig blant de elevene som hadde gjennomført to år i skole. Sammenføyningen av skoleopplæring hvor all ungdom har rett til inntak, og også til å få innfridd ett av tre valg, med overgang til læretid i bedrift hvor styringsretten avgjør hvem og hvor mange som tas inn i de ulike fag, var imidlertid langt fra uproblemtisk. Mange elever fikk ikke læreplass, og mange bedrifter fikk ikke lærlinger til sine fag. Myndighetene og partenes appeller om at bedriftene måtte slutte å tenke bare på egen rekruttering og i stedet se læreplasser som utdanningsplasser for ungdom, ble i for liten grad tatt til følge. Fortsatt var det bedriftenes mer kortsiktige arbeidskraftbehov, formet av de rådende konjunkturene, som dannet grunnlaget for lærlinginntak i de ulike fag, ikke prognoser for arbeidslivets fremtidige behov (Høst, Michelsen og Gitlesen 2008).

\subsection{Korrigeringer gjennom Kunnskapsløftet}

Selv om vi i dag i all hovedsak baserer oss på systemet som ble etablert $\mathrm{i}$ 1994, ble det foretatt visse korrigeringer av strukturen gjennom reformen Kunnskapsløftet i 2006. Da man i 1994 erstattet en yrkesspesifikk grunnkursstruktur (over 100 kurs) med brede innganger (12 kurs), beholdt man i stor utstrekning yrkesspesifikk spesialisering på det andre året. Dette ble 
senere oppsummert som dysfunksjonelt og som en viktig årsak til at man fikk den store graden av mismatch mellom læreplassøkere og - tilbud. ${ }^{37}$

Gjennom Kunnskapsløftet gikk man derfor videre med rasjonaliseringen og halverte antall kurs på andreåret gjennom å erstatte yrkesspesifikke kurs med bredere kurs basert på grupper av fag eller bransjer. Med dette grepet håpet man å oppnå flere ting; brede utdanninger skulle gjøre det enklere å etablere alle tilbud overalt, det skulle åpne for at elevene kunne utsette valg av fag til de er 18 år, og det ville gi arbeidslivet muligheter for å rekruttere lærlinger fra en bredere elevbase. Man beholdt imidlertid de omkring 200 ulike fagene i arbeidslivet, som på mange måter er grunnmuren i fagopplæringssystemet. Man har fortsatt nasjonale læreplaner, og hvert enkelt fag har etter reformen en kompetanseplattform.

Innholdsmessig begrunnes reformen med at elevene får en bredere kompetanse for å forstå arbeidslivet, ulike yrkers plasseringer og oppgaver i relasjon til hverandre og dermed et bedre grunnlag for både å velge og å gjennomføre spesialisering i et bestemt fag. Man mener en slik modell også er et bedre grunnlag for senere omstillinger. Parallelt med innføringen av bredere kurs på andreåret, innførte man imidlertid også det som kalles Prosjekt til fordypning. Gjennom dette skal elevene kunne benytte samlet i underkant av 400 timer i løpet av de to skoleårene, enten til å prøve ut ulike fag, fordype seg i ett lærefag de sikter mot, eller velge å gjennomføre fellesfag som skal til for å oppnå studiekompetanse for høyere utdanning. Prosjekt til fordypning kan altså på en og samme tid ses som en imøtekommelse av noen fags kritikk av for liten spesialisering og praksis i skoleopplæringen, samtidig som det er et tilbud som gir elevene muligheter for å orientere seg langt bredere, også teoretisk.

Historisk sett har Norge hatt et fag- og yrkesopplæringssystem hvor partene i arbeidslivet har vært delegert vide fullmakter for styring. Også her har strukturen blitt endret. Staten har trukket all styrings- og beslutningsmyndighet partene hadde inn i forvaltningen for å sikre seg grunnlag for en helhetlig styring av utdanningssystemet. Arbeidslivets parter har i stedet fått oppgaver av mer policyutformende karakter, primært å gi råd

37 St.meld (1998-99). St.meld.30 (2003-2004). 
om utforming av struktur, innhold i og dimensjonering av utdanningene. Om det sentrale Samarbeidsrådet for yrkesopplæringen (SRY) heter det således at det skal:

- arbeide for kvalitet og utvikling av fag- og yrkesopplæringen

- foreslå endringer i rammevilkårene for fag- og yrkesopplæringen

- foreslå hvilke kompetanseplattformer som skal inngå i videregående opplæring og drøfte strukturen på disse

- tilegne seg den mest relevante og treffsikre informasjon slik at rådet kan ligge i forkant av utviklingen innen yrkesopplæring 38

Historisk sett hadde hvert fag sitt råd som fulgte opp utviklingen av faget i forhold til endringer i arbeidslivet, grenser mot andre fag, utskilling av nye og sammenslåing med andre fag. Gradvis har dette systemet blitt rasjonalisert, og etter Kunnskapsløftet har man ni faglige råd som korresponderer med skolens yrkesfaglige utdanningsprogrammer. Disse skal dekke samtlige av de rundt 200 fag. Dette begrunnes med at det skal gi en mer effektiv utvikling av fag og yrker:

Målet med denne reduksjonen er å skape en bedre og mer effektiv utvikling av de yrkene som ligger til fag- og yrkesopplæringen. De faglige rådene skal arbeide for å utvikle kvaliteten i fagene og se trender og utviklingstrekk, slik at de dekker arbeidslivets, den enkeltes og samfunnets behov for kompetanse..$^{39}$

Tanken er at den nye måten å organisere det som nå er blitt et partsmedvirkningssystem skal ha et større blikk for helheten, og i mindre grad ta utgangspunkt i faginteresser. Ved å redusere antall råd antar man at myndighetene kommer tettere på arbeidslivet, og at man dermed får et bedre utgangspunkt for til en hver tid å kunne justere fagstrukturen i forhold til arbeidslivets behov framfor å styres av enkeltfagenes interesser.

$38 \mathrm{http}: / /$ www.skolenettet.no/moduler/templates/Module_Overview.aspx?id=12976\&epslanguage=NO

${ }^{39} \mathrm{http}: / /$ www.skolenettet.no/moduler/templates/Module_Overview.aspx?id=12829\&epslanguage=NO 
Figur 2.1: Søkning til videregående opplæring blant avgangselever fra grundskolen 2004-2009

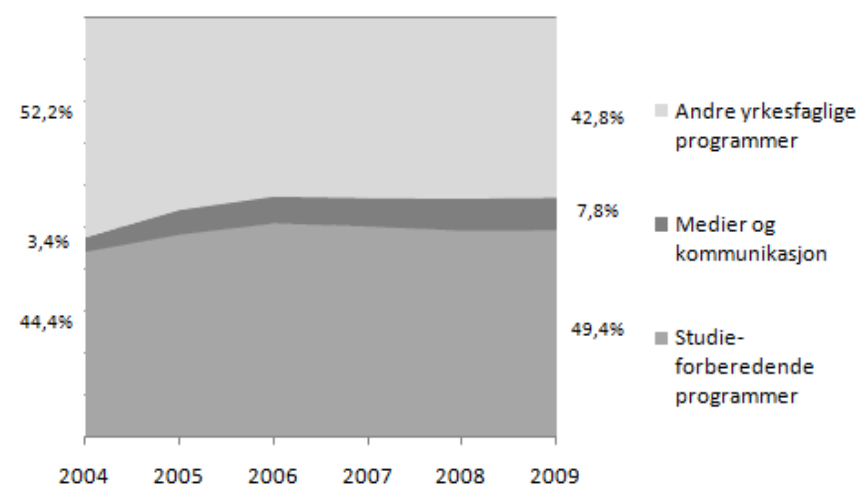

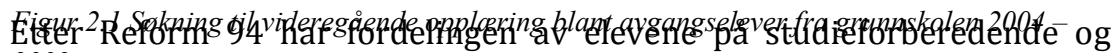
yrkesfaglige studieretninger/programmer i en lang periode ligget på rundt 50/50, med bare små variasjoner. Etter 2004 kan man imidlertid observere en klar trend i retning av at flere søker studieforberedende, færre yrkesfaglige tilbud frøseth m.fl. 2010. Holder man den formelt yrkesfaglige, men reelt studieforberedende retningen Medier og kommunikasjon utenfor, er trenden ganske dramatisk. Yrkesfagene har da fătt redusert sin andel fra 52 til 42 prosent fra 2004 til 2009 (figur 2.1)..40 Som vi skal komme tilbake til, forsterkes denne tendensen atskillig gjennom at rundt 12000 yrkesfagelever søker seg til påbygning til generell studiekompetanse.

\subsection{Den nye strukturen - noen erfaringer}

Det er det fylkeskommunale styringsnivået som har ansvaret for videregående opplæring i Norge, og som dermed ble gitt oppgaven med å oppfylle den rett til videregående utdanning ungdom fikk gjennom Reform 94. Det ble i etterkant av reformen oppsummert at fylkeskommunene hadde

40 Kilde: Frøseth. m.fl. (2010). 
liten frihet til å utforme politikk på området, men ble veldig styrt av ungdommens juridiske rett til utdanning og til å få innfridd ett av tre valg (Michelsen, Høst og Gitlesen 1998). Slik sett er det interessant å spørre om hvorvidt fylkeskommunene opplever at strukturendringene gjennom Kunnskapsløftet bidrar til endring. I tillegg til det nye systemet for partsmedvirkning, skulle bredere skolekurs gjøre det enklere å dimensjonere yrkesutdanningene, og ikke minst å tilpasse dem arbeidslivets behov.

Svarene fylkeskommunene og skolene gir både gjennom surveys og i dybdeintervjuer tyder imidlertid på liten endring etter Kunnskapsløftet (Høst og Evensen 2009). Det er utdanningsadministrasjonen og politikerne i fylkene som dominerer prosessen med å utforme utdanningstilbudet, og det er elevenes valg innenfor den nasjonale programstrukturen som legger de viktigste føringene når tilbudsstrukturen i fylkene utformes. Verken fylkeskommunene eller skolene mener den nye og bredere strukturen for yrkesfagene har betydd særlig endringer i hva de tilbyr. Arbeidslivets behov for kompetanse er av de momenter som legges vekt på, men det kommer ganske langt ned på listen (ibid.). Yrkesopplæringsnemnda, som er en politisk oppnevnt komité på fylkesnivå med representanter fra arbeidslivet, spiller en heller beskjeden rolle i dimensjoneringsarbeidet, til tross for at dette er en av hovedoppgavene til nemnda.

Prosessen med å dimensjonere yrkesutdanningene framstår som preget av inkrementalisme. Utdanningstilbudet er i utgangspunktet basert på klasseordningen fra året før. Denne avspeiler igjen mønsteret for elevsøkningen tidligere år, ofte justert for endringer i elevetterspørselen. På samme måte legger de lærekrefter og det utstyr skolene disponerer sterke føringer for hva man tilbyr, og dette er heller ikke forhold som normalt endrer seg raskt. Slik sett får man som regel bare små, gradvise endringer i tilbudsstrukturen. Selv om kursstrukturen etter Kunnskapsløftet er blitt bredere, er det likevel et klart inntrykk at de fleste skolene innenfor de brede kursene tilbyr fordypning i de fag de har hatt tidligere, og som de har lærere og utstyr til. Elever som ønsker annen fordypning, søker seg enten til andre skoler eller man forsøker å gi dem nødvendig fordypning gjennom praksis i bedrift eller ved hospitering på en annen skole. I første omgang har reformen på dette området fått karakter av å være en skinnreform. Dette er imidlertid forhold som kan endres etter hvert. 
Til tross for at dette tilsynelatende «trege» systemet i stor grad må sies å være styrt av elevenes valg, så formidles også arbeidslivets behov gjennom ulike mekanismer. For det første er det slik at bedriftenes behov slik de gir seg utslag i sysselsettingsstrukturen i arbeidslivet grunnleggende sett er avspeilet i tilbudsstrukturen for yrkesfagene. Gjennom bransjeorganisasjoner kan bedrifter være med på å utforme fagkategorier, utdanning og dimensjonering av disse. Med unntak av den store bølgen av nye fag som fulgte med Reform 94, er imidlertid også dette et arbeid som preges av inkrementalisme framfor store og brå endringer.

Arbeidsmarkedets muligheter formidles også til elevene gjennom den informasjon de får av familie, venner, media og andre kanaler, og bidrar slik sett til å påvirke elevenes valg. Det er likevel et klart inntrykk at fylkeskommunene ikke har funnet effektive metoder for hvordan de skal beregne arbeidslivets det fremtidige behov. Dette avspeiler også situasjonen på nasjonalt nivå, som vi skal komme tilbake til. Det som for fylkeskommunene framkommer som arbeidslivets behov er i stedet bedriftenes dagsaktuelle lærlingbehov. Om enkeltfag er så populære at de ikke kan tilby alle søkere en læreplass, slår dette inn i utdanningssystemet som da er lovpålagt å stille kostbare skoleplasser som erstatning. Dette var noe mange fylkeskommuner fikk smertelig erfare i de første årene etter Reform 9441, og har siden vært en situasjon de har forsøkt å unngå. Fylkeskommunene forsøker dermed, om enn i ulik grad, å begrense inntaket til kurs som leder mot antatt oversøkte lærefag. I fag der søkningen til læreplass er mindre enn bedriftenes behov, er fylkeskommunene mindre aktive. Dette gjelder langt de fleste fag. Konklusjonen er dermed at arbeidslivets behov for arbeidskraft, her uttrykt som behov for lærlinger, først slår inn hos fylkeskommunene når det truer dette systemets indre effektivitet og logikk.

Kunnskapsløftet skulle bedre effektiviteten i yrkesutdanningen gjennom at brede kurs skulle fjerne problemene med over- eller undersøkning til smalere kurs. Det har reformen til dels også gjort, men bare i skolen. I

${ }^{41}$ Hver fjerde læreplassøker ble i 1997/1997 tilbudt alternativ VKII i skole (Vibe, Edvardsen og Sandberg 1997). 
den andre enden, når elevene skal søke læreplass, ser de ut til å reprodusere de tidligere søkermønstre. Det betyr at fag som ikke fikk nok søkere før Kunnskapsløftet, heller ikke får det etter, selv om bredere kurs har utvidet deres rekrutteringsgrunnlag. Mangel på søkere gjelder for en del håndverks- og industrifag, men enda mer store fag innen tjenesteytende næringer som helsearbeiderfaget og salgsfaget. Ungdom søker seg i liten grad disse fagene, til tross for at rekrutteringsbehovet er stort.

\subsection{Overganger fra yrkes- til studieforberedende}

Ett annet uttrykk for søkerstyringen av det videregående utdanningssystemet er ordningen med å tilby elever som har fullført skoleutdanningen i yrkesfag å gjennomføre et påbygningsår med allmenne fag for å oppnå studiekompetanse i stedet for å fullføre fagbrev og yrkeskompetanse gjennom læretid. Overgangen til påbygning til studiekompetanse har blitt mangedoblet etter introduksjonen i 1994, og det har i enkelte fylker etter hvert blitt mer vanlig for yrkesfagelever å søke denne veien enn det er å søke læreplass. Innenfor yrkesfagprogrammer rettet mot tjenestesektoren, som Helse og sosial og Service og samferdsel, er det en langt større andel som hopper over på påbygning til studiekompetanse enn det er som søker læreplass. Ulike forslag og tiltak har vært foreslått, fra å gi alle som fullfører yrkesutdanningen studierett uten krav om mer allmennfag, til å strupe tilbudet av plasser i påbygningsklassene. Når et stort antall av de som begynner på en yrkesutdanning ender opp på et studiekompetansegivende løp, svekker dette også mulighetene til å tilpasse elevinntaket til læreplasstilbudet i de ulike yrkesfagene. På en måte kan dette trekket ses som uttrykk for det norske blandingssystemet. De områdene som mister særlig mange til påbygning til studiekompetanse har ikke noen (korporativ) tradisjon for å rekruttere gjennom lærefag, men tar i stedet inn ufaglærte for opplæring i virksomheten. 


\subsection{Statlig reformiver, skepsis blant fagene}

Den gradvise rasjonaliseringen av fag- og yrkesopplæringen, som startet på 1990-tallet, har hatt allmenn tilslutning. Omforente begrunnelser har vært at ungdom over hele landet skal ha tilgang på alle yrkesfaglige programmer uten å flytte, at elevene skal kunne utsette sine valg lengst mulig, at bedrifter innen alle lærefag skal ha tilstrekkelig tilgang på læreplassøkere, og at man gjennom dette skal få en bedre balanse og effektivitet $\mathrm{i}$ hele systemet.

Reformprosessen har imidlertid vært preget av at initiativet ligger i utdanningssystemet, mens arbeidslivets representanter til dels har vært noe nølende i sin tilslutning til endringene. Mange representanter i den gamle rådsstrukturen strittet mot å gi opp sine mer fagspesifikke kurs. I en offentlig utredning fra 2003 heter det således at

«...det har vært omtrent umulig å oppnå enighet om og rom for den forenklingen som er nødvendig for å gjøre fagopplæringen til en port inn i arbeids- og yrkeslivet og ikke en mur mot det.»42

Først gjennom oppnevning av medlemmer i en ny og rasjonalisert rådsstruktur med bare ni faglige råd klarte man å få tilstrekkelig støtte til å gjennomføre en halvering av antall andreårskurs (Vg2). Skepsisen til rasjonaliseringen av kursstrukturen på andreåret er heller ikke borte, fire år etter at dette ble gjennomført. Bygghåndverksfagene ønsker nå å reversere deler av reformen, ${ }^{43}$ mens sentrale arbeidslivsrepresentanter mener den brede kursstrukturen har gjort det utydelig hva elevene egentlig har vært gjennom av opplæring når de er ferdige med skoleopplæringen. ${ }^{4}{ }^{4}$

42 NOU 2003: 16 I første rekke.

43 Jf Brev fra Byggenæringens Landsforening til Utdanningsdirektoratet av 1. september 2010.

44 SRY-vedtak om gjennomgående dokumentasjon. 


\subsection{Like mange unge rekrutteres utenom lærlingsystemet}

Hvor stor del av arbeidslivet og ungdommen er omfattet av det som i prinsippet skal være et universelt lærlingsystem? Ser man på det enkelte ungdomskull, er det etter 1994 en kraftig økning i andelen som går direkte fra skolen og ut i et lærefag i bedrift. Rundt $1 / 6$ av hvert årskull går direkte ut i lære som 18-åringer. Av de ungdommene som begynner på et yrkesfaglig, går hver tredje ut i lære etter to år i skole. Tallet øker en del etter hvert, fordi en del blir lærlinger i litt høyere alder. Til tross for en ekspansjon, er det likevel et flertall, også av de som starter på en yrkesutdanning, som ikke blir lærlinger. En del hopper som omtalt over på påbygning til studiekompetanse. En betydelig del, rundt en tredjedel, fullfører ikke videregående opplæring, i hvert fall ikke i første omgang. Det mange ikke er klar over, er at de fleste av disse går inn i arbeidsmarkedet som ufaglærte. Det er for eksempel like mange fulltids sysselsatte under 20 år som er ufaglærte som det er lærlinger (Høst og Michelsen 2010). Også blant dem som fullfører med studiekompetanse går mange inn i arbeidslivet uten yrkesutdanning. Hva slags arbeidsmarked går disse inn i?

Ved siden av de bedriftene og bransjene som er omfattet av lærlingordningen og det vi kan kalle det yrkesbaserte arbeidsmarkedet, finnes det i Norge et stort arbeidsmarked basert på bedriftsintern opplæring av arbeidstakere uten relevant yrkesutdanning verken på videregående eller høyere nivå. Dette omfatter en betydelig del av arbeidsmarkedet innenfor tjenestesektoren. Til tross for at det er etablert fag og en lærlingordning som i prinsippet omfatter også denne delen av arbeidsmarkedet, fortsetter man her å rekruttere på den tradisjonelle måten. Det betyr at man ansetter uten særlig hensyn til utdanningsbakgrunn og lærer opp sine folk internt (Hagen et al 2010). Denne markedsbaserte formen for rekruttering og opplæring fanges slik sett ikke inn av det statlige/korporative systemet for yrkesutdanning og kompetanseplanlegging.

Årsakene til at man ikke har klart å integrere disse delene av arbeidsmarkedet i det organiserte yrkesutdanningssystemet er trolig sammensatte. Det er liten interesse blant ungdom for å bli lærlinger i disse fagene, noe som igjen medfører at også de bedriftene som kunne tenke seg å investere i slik opplæring fortsetter å rekruttere på den tradisjonelle måten. 
Den svake interessen kommer igjen av at ungdom ikke ser at en karriere i disse bedriftene går gjennom fagopplæringssystemet, fordi fagene her ikke er arbeidskraftkategorier med en klar plass i arbeidsdelingen. I stedet er karrierebanene basert på interne opplæringsordninger. Kort sagt; hvorfor skal man søke seg inn som lærling når man har et like godt utgangspunkt - og tjener langt bedre - som ufaglært ansatt? Det vil ikke være særlig å dristig å anta at dette også bidrar til at en så stor del av elevene på programmer som Helse og sosial og Service og samferdsel velger å hoppe av før de har fullført sin fagutdanning. Slik sett kan man si at denne formen for markedsbasert og uregulert opplæring av arbeidstakere også formidler sine behov til ungdom under utdanning, men da muligens i negativ forstand sett fra planleggernes side.

\subsection{Praksiskandidatordningen og fagskolen som fleksibel voksenopplæring}

Innenfor det norske blandingssystemet for rekruttering og opplæring $\mathrm{i}$ arbeidslivet spiller den såkalte praksiskandidatordningen en viktig rolle ved å øke fleksibiliteten både på arbeidstaker- og bedriftssiden. Den gir en åpning for sertifisering og fagbrev for mange ansatte som ikke har gjennomført læretid, men som har startet som mer eller mindre ufaglærte i bedrift. På samme måte sørger den slik sett for en forsyning av faglært arbeidskraft til mange av de bedriftene som ikke får et tilstrekkelig antall lærlinger gjennom det ordinære systemet. For å få lov til å gå opp til fagprøve som praksiskandidat må en ha minst fem års fartstid som ufaglært innen fagområdet.

Omfanget av praksiskandidatordningen er betydelig. I lange perioder har praksiskandidatene utgjort i underkant av $50 \%$ av alle som avlegger fagprøve (Michelsen og Høst 2002). De senere årene har andelen ligget på rundt $30 \% .45$

\footnotetext{
45 I 2008-2009 ble det avlagt 6400 fagprøver blant praksiskandidater, mens det ble avlagt 14000 fagprøver blant lærlinger (Statistisk sentralbyrå).
} 
Ordningen har vært viktig både innenfor tradisjonelle fagområder som ikke får tilstrekklig med faglærte eller lærlinger, men også innenfor nye fagområder hvor det å sertifisere ufaglærte ansatte med lang fartstid kan være en måte å bygge opp et nytt fag. Samtidig kan det bidra til en sementering av mønstrene med å rekruttere ufaglærte. Kravene for å bli sertifisert impliserer imidlertid at en har lært seg et fag, som gir en langt bredere kompetanse enn det som normalt ligger i bedriftsintern opplæring. Så lenge fagstandardene opprettholdes, så fungere dette dermed som en forlengelse av fagopplæringssystemet og ikke det bedriftsinterne opplæringssystemet.

Det norske fagskolesystemet representerer egentlig et mellomnivå mellom yrkesutdanning og høyere utdanning. Store områder innenfor dette systemet er teknisk fagskoleutdanning, helse og sosial, økonomiske og administrative fag. Selv om det primært skal gi en videreutdanning for de med fagutdanning, rekrutterer det også voksne uten videregående opplæring, eller yrkesutdanning, og det rekrutterer også til fagområder som det videregående utdanningssystemet ikke klarer å dekke, ikke minst innenfor tjenestesektoren.

\section{$4.100 \mathrm{~m}$ fremtidsplanlegging}

Fremskrivninger av tilbud og etterspørsel etter ulike typer arbeidskraft utarbeides i Norge av Statistisk Sentralbyrå (SSB), ${ }^{46}$ men også av enkelte bransjeorganisasjoner, oftest da på grunnlag av blant annet SSB-tall. SSBs framskrivninger er basert på den makroøkonomiske modellen MODAG og mikrosimuleringsmodellen MOSART. Modellen er nødvendigvis grov, og i stor grad basert på videreføringer av den erfarte trenden de siste 25 år med hensyn til økt utdanningstilbøyelighet, samtidig som det også korrigeres noe for forventninger om næringsmessige forskyvninger. På et overordnet nivå forteller fremskrivningene ikke overraskende at det er tertiærnæringene som vil vokse, mens både primær- og sekundærnæringene vil fortsette å gå tilbake. Når det gjelder utdanningsnivå forventer

${ }^{46}$ Se blant annet Bjørnstad m. fl. (2010). 
man størst økning i antall arbeidstakere med høyere utdanning av lavere grad, men det forventes også en sterk økning i antall med yrkesutdanning på videregående nivå. Størst økning rent kvantitativt forventes i elektrofag, mekaniske fag og motortekniske fag, men det ventes også sterk økning i pleie- og omsorgsfag, samt fag knyttet til bygg- og anleggssektoren. Kombinasjonen av et fortsatt stramt arbeidsmarked og en betydelig andel som ikke gjennomfører videregående opplæring, fører til en forventning om et fortsatt betydelig arbeidsmarked for såkalt ufaglærte - selv om en avtakende tendens forventes. Dette igjen impliserer en betydelig grad av bedriftsintern opplæring også i overskuelig framtid.

Som planleggingsinstrument for yrkesopplæring på videregående nivå blir fremskrivningene veldig generelle og grove. Det er ikke lagt inn endringer som følge av konjunktursvingninger, og anslagene over fordelingen av ansatte på ulike utdanningsnivåer i den enkelte næring er og må nødvendigvis være usikre. Denne vil avhenge av en rekke størrelser det ikke er mulig å fastlegge for fremtiden, som ulike yrker og profesjoners styrke, de unges utdanningstilbøyelighet, måten teknologi blir utviklet og anvendt på og virksomhetenes valg av organisasjonsmodeller.

\subsection{Oppsummerende drøfting}

Fremdeles foregår den mest effektive formidling av kompetansebehov fra arbeidslivet til utdanningssystemet via lærlingordningen og fagene i arbeidslivet. Både kvalitativt gjennom formidling av behov for endring $\mathrm{i}$ fagenes innhold, og kvantitativt gjennom formidling av behov for læreplasser, har dette systemet spilt og spiller en sentral rolle. Yrkesutdanningssystemets integrering i det offentlige utdanningssystemet har gitt staten en mer fremtredende plass i systemet på bekostning av den tradisjonelle korporative styringen. Myndighetene har også tatt initiativet til å gjøre utdanningsprogrammene i skolen langt bredere og de faglige rådene færre. Tanken er at dette skal gjøre det lettere å dimensjonere utdanningssystemet og fortløpende tilpasse seg arbeidslivets behov. Foreløpig er det vanskelig å observere effekter av dette.

Staten har også vært en pådriver for utvidelsen av fagopplæringssystemet til også å omfatte bransjer der fagopplæring historisk sett ikke hatt 
feste. Til tross for reformene befinner imidlertid en stor del av arbeidslivet seg fortsatt i utkanten av dette systemet og rekrutterer hovedsakelig ufaglært arbeidskraft. Kompetansesignalene herfra kan sies å være doble i forhold til yrkesutdanningssystemet, dvs. at selv om bransjene signaliserer behov for en viss type faglært arbeidskraft, så ser ungdom at veien inn i dette segmentet av arbeidsmarkedet like gjerne kan gå via skoleavbrudd eller generell studiekompetanse, som det å ta en fagutdanning.

Fremskrivninger av behov for arbeidskraft i Norge gjøres på et veldig overordnet nivå. Disse viser stort sett til et økende behov innenfor fagområder som allerede sliter med å rekruttere tilstrekkelig. Dette illustrerer den særegne karakteren planlegging av yrkesutdanning har i Norge; over lange perioder har hatt tilnærmet full sysselsetting; søkernes egne ønsker er viktigste styringsparameter, og bemanning av jobbene styres i stor grad av arbeidstilbudet. 


\section{De danske erhvervsuddannelser og arbejdsmarkedet}

Christian Helms Jørgensen, Roskilde Universitetscenter

\subsection{Indledning}

Hvordan sikres det at de danske erhvervsuddannelser løbende tilpasses til arbejdsmarkedets behov for kompetencer - både de aktuelle og de fremtidige behov? Dette spørgsmål vil rapporten her forsøge at besvare. Gennem de seneste ti år har Undervisningsministeriet i Danmark sat mere fokus på uddannelsernes relevans for arbejdsmarkedet blandt andet ved en tæt monitorering af beskæftigelsesfrekvenser for de uddannede. Det begrundes med fremtidens demografisk betingede mangel på arbejdskraft, globaliseringen og de hastige forandringer på arbejdsmarkedet samt EU-politikkens tiltag i forhold til „employability“. Rapporten her beskæftiger sig kun med erhvervsuddannelserne på gymnasialt niveau (10.-12. klassetrin).

Det danske uddannelsessystem adskiller sig især fra de øvrige nordiske lande ved den stærke opdeling af ungdomsuddannelserne i et studieforberedende spor og et erhvervsrettet (yrkesrettet) spor. Den traditionelle mesterlære (lærlingeuddannelse) blev reformeret i 1970erne og erstattet med en erhvervsuddannelse, der for langt de fleste starter med $1 / 2-1$ års skoleundervisning normalt efterfulgt af 3 års virksomhedspraktik, der veksler med 10-12 ugers skoleundervisning om året. De store reformer i henholdsvis 1991 og 2000 og en række mindre har bidraget til at modernisere erhvervsuddannelserne og udbrede en ensartet model af vekseluddannelser til nye områder af arbejdsmarkedet. De erhvervsfaglige uddannelsers selvstændige profil giver skoletrætte unge et værdifuldt 
alternativ til den akademiske uddannelsesvej og medfører at danske unge har en meget lav andel af ikke-aktive unge (Eurostat 2009:104).

Erhvervsuddannelserne varetager fortsat uddannelsen af mere end en tredjedel af en ungdomsårgang. De har historisk en tæt tilknytning til arbejdsmarkedet i kraft af deres indhold, organisering og styring. De er tilrettelagt som vekseluddannelser (dualt system), hvor omkring 2/3 af uddannelsestiden foregår som ansat i en virksomhed med løn reguleret af overenskomster mellem arbejdsmarkedets parter. Denne uddannelsesform indebærer i sig selv at oplæringen svarer overens med de kompetencer som aktuelt er relevante på arbejdsmarkedet. Desuden sikrer virksomhedspraktikken en god integration af de unge på arbejdsmarkedet som en integreret del af uddannelsesforløbet. Omkring halvdelen af eleverne fortsætter i beskæftigelse i den virksomhed, hvor de er uddannet. Samtidig har arbejdsmarkedets parter stor indflydelse på udformningen af uddannelserne via det faglige selvstyre. Det bidrager til uddannelsernes legitimitet og til at de kompetencer som uddannelserne formidler, er anerkendt på arbejdsmarkedet. Det viser sig ved en høj beskæftigelsesfrekvens for unge der afslutter en erhvervsuddannelse (Gangl 2001; Wolbers 2007), og en meget lav ungdomsarbejdsløshed i Danmark set i internationalt perspektiv (Breen 2005; AER 2010; Eurostat 2009:104). Uddannelserne er baseret på erhvervsfag (yrker) som giver en tæt forbindelse mellem uddannelse og arbejdsområde. Erhvervsfagene bidrager til at skabe gennemsigtighed i forholdet mellem uddannelse og arbejde ved at fungere som „vejvisere“ for de unges uddannelsesvalg. Den tætte kobling mellem uddannelse og arbejde betyder, at næsten alle med en erhvervsuddannelse (85-90 \%) får et arbejde, der er på niveau med uddannelsen (AE Rådet 2010). Personer med en erhvervsuddannelse kommer hurtigere i arbejde efter afsluttet uddannelse end personer med en lang videregående uddannelse, og forekomsten af overuddannelse for erhvervsuddannede er kun halvt så hyppigt (AE Rådet 2010). Det svarer til fund for duale systemer i den internationale forskning (Szydlik 2002; Müller \& Shavits 1998). Erhvervsuddannelserne har en stor faglig bredde og nationalt standardiserede kompetenceprofiler. Den faglige bredde medfører at de faglærte i Danmark har en høj funktionel fleksibilitet (mobilitet mellem jobfunktioner). De standardiserede kompetenceprofiler medfører, at de har en høj numerisk fleksibilitet (mobilitet mellem virksomheder). Mobiliteten er 
blandt de højeste i EU og den indgår som del af den danske "flexicurity“ model (Jørgensen \& Madsen 2007). Uddannelsernes kobling til arbejdsmarkedet er formidlet via et praktikpladsmarked, og dimensioneringen af uddannelserne er både styret af virksomhedernes udbud af praktikpladser, som i nogen grad afspejler beskæftigelsesstrukturen, og af de unges valg af uddannelser.

Rapporten vil først beskrive, hvordan imødekommelsen af arbejdsmarkedets behov indgår i styringen af erhvervsuddannelserne på forskellige niveauer. Dernæst vil den vurdere den mest udbredte metode til at sikre arbejdsmarkedets kompetencebehov, kvalifikationsanalysen. Der peges på to gode erfaringer fra „den danske model“ for samspil med arbejdsmarkedet: det faglige selvstyre og vekselprincippet. Dernæst diskuteres det om erhvervsuddannelserne er tilstrækkeligt responsive i forhold til både de aktuelle og de fremtidige behov for kompetencer, og om de mekanismer som skal sikre dette, fungerer tilfredsstillende. Det handler især om de to væsentligste svagheder, manglen på praktikpladser og et højt frafald, og nogle af initiativerne til at udbedre disse svagheder vurderes.

\subsection{Hvordan sikres arbejdsmarkedets behov i styringen af uddannelserne?}

Arbejdsmarkedets behov er på ingen måde nogen entydig størrelse. Behovene kan formuleres på mange niveauer og på kort eller langt sigt. Det særlige ved det danske system er at arbejdsmarkedets behov for kompetencer overvejende defineres på niveau af erhvervsfagene. Behovene som artikuleres på dette niveau er på den ene side mere generelle end enkeltvirksomhedernes behov og på den anden side mere specifikke end det samlede arbejdsmarkeds behov. Denne måde at definere de aktuelle og fremtidige kompetencebehov skyldes den styringsform, som erhvervsuddannelserne i Danmark er underlagt. Styringen af erhvervsuddannelserne er primært baseret på et fagligt selvstyre (partsstyre), som dog udøves i kombination med statsstyring og markedsregulering. Gennem det faglige selvstyre overlader staten en del af styringen af uddannelserne til arbejdsmarkedets parter. Denne styringsform hænger sammen med at uddannelserne er vekseluddannelser, hvor arbejdsgiverne stiller praktik- 
pladser til rådighed og tager ansvaret for oplæringen af elever under det meste af deres uddannelsestid (Juul \& Jørgensen 2011).

Det faglige selvstyre fungerer via selvstændige institutioner, primært de faglige udvalg, som forpligter arbejdsmarkedets parter til at forfølge fælles interesser på et mere aggregeret niveau end den enkelte virksomhed. Det faglige selvstyre har en mellemposition mellem stat og marked. Det er på den ene side ikke er direkte underlagt markedets krav om kortsigtet tilpasning af arbejdskraften til virkernes specifikke behov, og på den anden side heller ikke er direkte underlagt statens krav og interesser. Gennem det faglige selvstyre kan personer, som er tæt på virksomhederne, formulere aktuelle behov arbejdsmarkedet og samtidig sammenfatte fagområdets generelle behov og ud fra dette fastlægge nationale standarder for de enkelte uddannelser. De faglige udvalg kan desuden formulere mere langsigtede strategier for uddannelserne (Greinert 1999).

Den statslige styring udøves primært i forhold til skoledelen af erhvervsuddannelserne og vedrører politisk definerede opgaver af samfundsmæssig interesse. Det handler om uddannelse til samfundsborgerskab, social integration af marginaliserede unge og mere aktuelt et politisk ønske om undervisning i iværksætteri, innovation og internationalisering. Desuden forsøger staten at tilpasse erhvervsuddannelsernes udvikling i forhold til det øvrige uddannelsessystem. Den statslige regulering baseres ofte på generelle prognoser og scenarier for det fremtidige kompetencebehov, som anvendes til ressourceallokering til forskellige dele af uddannelsessystemet samt dimensionering via adgangsbegrænsning.

Markedsreguleringen foregår især på to områder: ved de unges valg af uddannelser og skoler, og ved virksomhedernes udbud og besættelse af praktikpladser. Det betyder at antallet af elever på de enkelte uddannelser (dimensioneringen) styres af en ret uforudsigelig og uigennemsigtig proces, som ikke har nogen direkte forbindelse med arbejdsmarkedets fremtidige behov for arbejdskraft. På den ene side afspejler udbuddet af praktikpladser til en vis grad beskæftigelsesstrukturen, men på den anden side kan udbuddet af praktikpladser i virksomhederne forstærke en konjunkturelt bestemt mangel på arbejdskraft. Det skyldes at nedgangen i udbuddet af praktikpladser ved starten af en konjunkturnedgang kan medføre mangel på faglært arbejdskraft 4 år senere, når konjunkturerne er på vej 
op. Spørgsmålet om praktikpladser er centralt og vil blive vurderet nærmere senere i rapporten her.

Først vil vi se nærmere på hvordan arbejdsmarkedets behov artikuleres i forhold til styringen på fire niveauer jævnfør figuren. Reguleringen af erhvervsuddannelsernes indhold, varighed, struktur og kvalitet er delt mellem Undervisningsministeriet, Rådet for de Grundlæggende Erhvervsfaglige Uddannelser, de faglige udvalg for de enkelte uddannelser og de erhvervsskoler, som er godkendt til at udbyde uddannelserne.

\begin{tabular}{|c|c|c|c|}
\hline Niveau & Statslig styring & Faglige selvstyre & Styringsmedier \\
\hline Centralt & $\begin{array}{l}\text { Undervisningsministeriet } \\
\text { Afdelingen for erhvervsuddan- } \\
\text { nelser }\end{array}$ & $\begin{array}{l}\text { Rådet for grundlæggende } \\
\text { Erhvervsrettede Uddannelser, } \\
\text { REU }\end{array}$ & $\begin{array}{l}\text { Lovgivning } \\
\text { Finansiering (ex } \\
\text { puljer til udviklings- } \\
\text { opgaver) }\end{array}$ \\
\hline Branche & $\begin{array}{l}\text { Undervisningsministeriets } \\
\text { fagkonsulenter }\end{array}$ & $\begin{array}{l}\text { Faglige udvalg for uddannel- } \\
\text { sen f.eks. Industriens Uddan- } \\
\text { nelser }\end{array}$ & $\begin{array}{l}\text { Uddannelsesordnin- } \\
\text { ger } \\
\text { Godkendelse af } \\
\text { praktikvirksomheder }\end{array}$ \\
\hline \multirow{2}{*}{$\begin{array}{l}\text { Lokalt } \\
\text { Virksomhed } \\
\text { Skole }\end{array}$} & $\begin{array}{l}\text { Erhvervsskoler } \\
\text { F.eks. taxameterstyring }\end{array}$ & $\begin{array}{l}\text { Skolebestyrelser } \\
\text { Lokale uddannelsesudvalg }\end{array}$ & $\begin{array}{l}\text { Lokale undervis- } \\
\text { ningsplaner }\end{array}$ \\
\hline & $\begin{array}{l}\text { Virksomheder } \\
\text { F.eks. tilskud til praktikpladser }\end{array}$ & $\begin{array}{l}\text { Virksomhedens samarbejds- } \\
\text { udvalg eller uddannelsesud- } \\
\text { valg }\end{array}$ & Uddannelsesplaner \\
\hline Deltager & Personlige uddannelsesplaner & Faglige Udvalg behandler & Uddannelsesbog \\
\hline Elev, lærling & Uddannelsesvejledning & $\begin{array}{l}\text { klager fra lærlinge over } \\
\text { oplæringen }\end{array}$ & Logbog (Elevplan) \\
\hline
\end{tabular}

\subsection{Undervisningsministeriet}

Undervisningsministeriet har det overordnede økonomiske og juridiske ansvar for erhvervsuddannelserne, som er reguleret gennem lovgivningen. Undervisningsministeriet har primært ansvar for skoleundervisningen, mens de faglige udvalg har det primære ansvar for praktikdelen af uddannelserne, for eksempel med hensyn til varigheden af uddannelserne. Undervisningsministeriet fører tilsyn med erhvervsskolerne, mens de faglige udvalg fører tilsyn med den praktiske oplæring i praktikvirksom- 
heder. Det er Undervisningsministeriet som fastlægger rammerne for institutionernes uddannelsesmæssige, økonomiske og retlige forvaltning, og som har ansvaret for godkendelse af institutionernes vedtægter. I 1960-70erne forsøgte staten at styre det samlede uddannelsessystems udvikling med en samlet uddannelsesplanlægning på grundlag af prognoser og politiske prioriteringer. Det afløstes fra starten af 1980erne af et skifte til øget markedsregulering, hvor skolerne i højere grad skal operere som virksomheder på et uddannelsesmarked og hvor de unge og virksomhederne får en rolle som (for-)brugere. Med en reform i 1991 skete der en decentralisering, hvor opgaver og beslutningskompetence er flyttet fra undervisningsministeriet og ud til de enkelte erhvervsskoler. Det har givet skolerne større muligheder for at tilpasse undervisningen til lokale arbejdsmarkeds behov. Det kunne have ført til en undergravning af de nationalt standardiserede erhvervsfags ensartede profiler. Det er ikke sket, blandt andet fordi lokalt udbudte uddannelser ikke har nogen større arbejdsmarkedsværdi, når de ikke er godkendt af arbejdsmarkedets parter. Samtidig har ministeriet udvidet sit tilsyn med institutioners resultater og kvalitet gennem årlige tilsynsplaner, der udstikker prioriteringer og de indikatorer, som de enkelte skoler måles på. Det gælder for eksempel skolernes økonomiske resultater og frafaldet, som fremgår af skolens obligatoriske handlingsplaner for fastholdelse, som skolerne årligt skal indsende til ministeriet. Ministeriet har også øget kravene til de faglige udvalg om at de løbende dokumenterer at uddannelserne svarer overens med arbejdsmarkedets behov. Ministeriet har især fokus på kompetencebehov, som går på tværs af de eksisterende erhvervsfag (yrker) og helt nye beskæftigelsesområder som ikke endnu er uddannelsesdækket. På baggrund af beskæftigelsessituationen inden for et fagligt område kan Undervisningsministeriet indføre adgangsbegrænsning til hovedforløbet for nogle uddannelser for de elever, der ikke i forvejen har en uddannelsesaftale. I 2010 er der 12 erhvervsuddannelser med adgangsbegrænsning primært indenfor populære uddannelser som medie, frisør og fotograf, hvor der ikke er udsigt til at der kan skaffes praktikpladser eller beskæftigelse til alle de unge, som søger. Desuden regulerer ministeriet adgangen til skolepraktikordningen, som er et tilbud til de elever som ikke kan finde praktikplads i en virksomhed. En del uddannelser udbydes slet 
ikke i skolepraktik, og for andre uddannelser fastsættes der kvoter på antallet af pladser i skolepraktikken.

\subsection{Rådet for de grundlæggende Erhvervsrettede Uddannelser (REU)}

Det øverste organ for det faglige selvstyre er Rådet for de grundlæggende Erhvervsrettede Uddannelser (REU). Det er sammensat af 30 medlemmer, der hovedsagligt repræsenterer arbejdsmarkedets parter, men også de øvrige interessenter på området: kommuner, skoler, elever og lærere. REU har som opgave at rådgive undervisningsministeren på et overordnet niveau om erhvervsuddannelserne. REU giver indstillinger om oprettelse og nedlæggelse af uddannelser, om hvilke uddannelser der kan udbydes med skolepraktik og om adgangsbegrænsning til uddannelser eller til skolepraktik. Det sker blandt andet på baggrund af en årlig sammenfatning af de faglige udvalgs udviklingsredegørelser og beskæftigelsessituationen for uddannelserne. Der er en stærk tradition for konsensus mellem parterne og for at staten følger indstillinger fra parterne - om end der er undtagelser, for eksempel ved indførelsen af korte erhvervsuddannelser i 2004.

\subsection{De faglige udvalg}

De faglige udvalg har til opgave at følge udviklingen på arbejdsmarkedet, og de skal efter behov tage initiativ til nyetablering, omlægning og nedlæggelse af uddannelser. De faglige udvalg skal sammen med praktikvirksomhederne kvalitetsudvikle og kvalitetssikre uddannelsernes praktikdel. Udvalgene godkender desuden praktikvirksomheder, ansøgninger om afkortning eller forlængelse af uddannelser og fører tilsyn med oplæringen i virksomhederne, og er herunder klageinstans for lærlinge og virksomheder. De 48 faglige udvalg har således en central rolle i reguleringen af uddannelsernes indhold og struktur. Udvalgene er paritetisk sammensat af repræsentanter for arbejdsmarkedets parter, og fastlægger ensartede nationale kompetenceprofiler for hver erhvervsuddannelse. De nationale standarder er en vigtigt forudsætning for den meget høje mobilitet, 
som findes på det danske arbejdsmarked. Parternes aktive deltagelse og „ejerskab“ sikrer desuden at erhvervsuddannelserne nyder bred anerkendelse på arbejdsmarkedet. Udvalgene dækker hver et brancheområde med en eller flere uddannelser, og de dækker tilsammen alle branche- og uddannelsesområder. De faglige udvalg definerer uddannelsens mål og øvrige rammer for undervisningens indhold, for eksempel eventuelle niveaukrav. Udvalgene definerer også indholdet i reglerne for praktikuddannelsen og uddannelsens tilknytning til en eller flere fællesindgange. Det er dog Undervisningsministeriet, som fastsætter reglerne på baggrund af udvalgenes ønsker. De faglige udvalg fastsætter uddannelsesordninger for de enkelte uddannelser på grundlag af uddannelsesbekendtgørelserne.

For at sikre arbejdsmarkedets behov skal de faglige udvalg hvert år i en udviklingsredegørelse for hver uddannelse beskrive den faktiske udvikling i elevtal, fuldførelsesprocent, beskæftigelsesfrekvens, omfang af skolepraktik og videreuddannelsesfrekvens. Desuden skal udvalgene analysere områdets teknologiske udvikling, de internationale forhold, eventuelt ændrede organisations- og reguleringsformer og vurdere det fremtidige behov for faglært arbejdskraft indenfor området samt vurdere udviklingen på tilgrænsende faglige områder og praktikpladssituationen. Specifik skal udvalgene derefter forholde sig til om der er behov for omlægning, nedlægning eller nyetablering af uddannelser. Endelig skal udvalgene redegøre for, hvordan de fører tilsyn den praktiske oplæring i virksomhederne blandt andet via de lokale uddannelsesudvalg som fungerer ved alle erhvervsskoler. En sammenfatning af de faglige udvalgs redegørelser viste, at der i 2009 var planer om oprettelse af 5 nye erhvervsuddannelse og nedlæggelse af 10 eksisterende samt planer om ændringer i 85 uddannelser (Undervisningsministeriet 2010). Ministeriet ser dette som udtryk for at formålet med redegørelserne er opfyldt, nemlig at sikre en bedre og hurtigere uddannelsesdækning af nye beskæftigelsesområder, og at alle faglige udvalg fokuserer på fornyelse af uddannelserne 


\subsection{Erhvervsskolerne}

Erhvervsskolerne dækker først og fremmest det lokale og regionale arbejdsmarked, men nogle skoler udbyder også specialiserede uddannelser på nationalt plan. Sammenlignet med andre nordiske lande har de danske erhvervsskoler en svag tilknytning til det kommunale niveau. I erhvervsskolernes bestyrelser deltager dog mindst en repræsentant fra de lokale kommuner og fra arbejdsmarkedets organisationer i området, som skal være ligeligt repræsenteret. Ved hver erhvervsskole er der i samarbejde med de faglige udvalg nedsat et lokalt uddannelsesudvalg, som primært repræsenterer parterne på det lokale arbejdsmarked. Der nedsættes et lokalt uddannelsesudvalg for hver uddannelse, som erhvervsskolen udbyder, dog kan et udvalg godt dække flere uddannelser. Udvalgene har til opgave at sikre samarbejdet imellem skolen og det lokale erhvervslivs aktuelle og forventede uddannelsesbehov. Skolerne og de faglige udvalg skal samarbejde med de lokale uddannelsesudvalg om at skaffe praktikpladser i nødvendigt omfang. Skolerne fastlægger i samarbejde med de lokale uddannelsesudvalg det nærmere indhold i undervisningen og fremkommer med forslag til fornyelse af uddannelsesreglerne. Udvalget skal medvirke til, at uddannelsen både lever op til centralt fastsatte krav og er tilpasset lokale forhold og den faglige udvikling på området. Skolen skal udarbejde lokale undervisningsplaner for hver uddannelse i samarbejde med det lokale uddannelsesudvalg.

Med henblik på at sikre at undervisningen er relevant i forhold til arbejdsmarkedet, er det et krav at faglærere har både en grundlæggende erhvervsrettet uddannelse og videreuddannelse indenfor det område de underviser i, samt en relevant erhvervserfaringen af mindst 5 års varighed. Desuden har lærerne i en vis udstrækning kontakter med elevernes praktikvirksomheder blandt andet via praktikbesøg og møder med virksomhederne på skolen. Erhvervsuddannelsernes tilrettelægges som en vekslen mellem skolebaseret undervisning og praktisk oplæring i en virksomhed betyder at elevernes integration på arbejdsmarkedet er indbygget i uddannelserne. Det har dog i mange år været en udfordring at få elevernes læring i de to læringsmiljøer til at hænge sammen, fordi skole og virksomhed har forskellige kulturer og rationaler. Et eksempel på en god praksis med hensyn til at skabe samspil mellem skole og virksomhed er 
det såkaldte praktikum som er skrevet ind i nogle uddannelsesordninger. I praktikum bygges samarbejdet op om udviklings- eller arbejdsopgaver som eleven arbejder med på tværs af de to læringsmiljøer.

\subsection{Virksomheder og de unge}

Et afgørende element i erhvervsuddannelserne er virksomhedspraktikken. Siden eleverne i 1972 fik mulighed for at starte en erhvervsuddannelse på en skole, har manglen på praktikpladser været et tilbagevendende problem, som har hindret unge i at gøre den uddannelse færdig, som de var startet på. Virksomhedsoplæringen er for hver uddannelse reguleret af en uddannelsesbekendtgørelse og en uddannelsesordning, som udarbejdes af de faglige udvalg, som også fører tilsyn med oplæringen. Det skal sikre at oplæringen har den faglige bredde, der er fastlagt i de nationale kompetenceprofiler. Det er afgørende for den høje beskæftigelsesfrekvens og den høje mobilitet som kendetegner de faglærte i Danmark. Omkostningerne ved oplæring af lærlinge deles i nogen grad solidarisk mellem alle virksomheder, som indbetaler til en fond (arbejdsgivernes elevrefusion, AER) som finansierer udgifter til lærlingenes løn under skoleophold.

Uddannelsespolitikken lægger vægt på at give de unge frit valg af ungdomsuddannelse, men søger samtidig at styre elevstrømmene i retning mod arbejdsmarkedets behov. Det sker blandt andet gennem et system af uddannelsesvejledning som blev udbygget med etableringen af Ungdommens Uddannelsesvejledning (UU centre) i alle kommuner fra 2004. Desuden skal eleverne i folkeskolens ældste klasser udarbejde uddannelsesplaner, som grundlag for overgangen fra folkeskole til ungdomsuddannelse. Med „Ungepakken“ fra 2010 er det forbundet med sanktioner, hvis de unge ikke følger deres uddannelsesplan og hverken er under uddannelse eller i beskæftigelse. Også på erhvervsskolerne tilbydes uddannelsesvejledning til eleverne, især til frafaldstruede elever og elever som ikke kan skaffe en praktikplads og som derfor har behov for at søge nye uddannelsesveje. I forbindelse med skiftet fra statslig styring til markedsregulering var forventningen, at de unges uddannelsesvalg ville være økonomisk rationelt. Det vil sige at valget ville orientere sig mod de uddannelser, der har god beskæftigelse og høj løn, og at mekanismerne på „uddannelses- 
markedet" derfor ville tilgodese arbejdsmarkedets behov. Der er dog klare tegn på at unges uddannelsesvalg i højere grad er styret af uddannelsernes kulturelle værdi og af de unges personlige interesser end af uddannelsernes arbejdsmarkedsværdi (Humlum 2009; DCUM 2006). Derfor griber staten stadig ind med direkte styring af dimensioneringen af især „modeuddannelser", hvor der søger langt flere unge ind, end der er praktikpladser og beskæftigelse til.

\subsection{Voksen- og efteruddannelsessystemet}

De grundlæggende erhvervsuddannelsers (IVET) samspil med arbejdsmarkedet må ses i sammenhæng med voksen- og efteruddannelsessystemet, VEU-systemet (CVET), der også styres af arbejdsmarkedets parter. VEU-systemet spiller en afgørende rolle for at sikre at personer med en erhvervsuddannelse til stadighed holder denne uddannelse ajour, og for at sikre en høj mobilitet på arbejdsmarkedet blandt andet via et højt niveau af aktiv arbejdsmarkedspolitik (ALM). VEU-systemet indeholder meget omfattende tilbud til både faglærte og ikke-faglærte, og Danmark har i en årrække været det land i EU, som har haft den højeste deltagelse i VEU (Eurostat 2009). Der er generelt enighed om at en kollektiv finansiering er nødvendig, fordi den høje mobilitet på det danske arbejdsmarked svækker de private virksomheders incitamenter til at investere i kompetenceudvikling af egen arbejdskraft (Bowman 2005). Der er dog sket et skifte fra en statslig finansiering i retning mod en øget deltagerbetaling samt en finansiering fra arbejdsmarkedets parter blandt andet gennem kompetencefonde som i 2007 blev aftalt i overenskomsterne. Utilstrækkelige almene kundskaber udgør en barriere for at en del af arbejdsstyrken kan deltage i efter- og videreuddannelse. Det har været en svaghed ved de danske voksenuddanelser at de erhvervsrettede (AMU) og de almene uddannelser (AVU) er udbudt af hver sine institutioner. Etableringen i 2009 af de 13 nye VEU-centre som dækker hele landet samler begge typer af uddannelser under et tag. De bygger blandt andet på flere års gode erfaringer med at tilbyde almen Forberedende Voksenuddannelse (FVU) i kombination med arbejdsmarkedsuddannelser (AMU). 
Historisk er en del faglærte blevet uddannet som voksne. Det er blandt andet sket ved at ufaglærte med lang arbejdserfaring af de faglige udvalg har fået anerkendelse som faglærte efter ansøgning og eventuelt en svendeprøve. I første halvdel af 1990erne lå antallet af voksenlærlinge på 23.000 nye lærlinge hvert år. Voksenlærlingeordningen med statsligt tilskud blev indført som midlertidig forsøgsordning i 1997 og gjort permanent i 1999. Den har til formål at give voksne bedre muligheder for at tage en erhvervsuddannelse. Ordningen giver et statsligt løntilskud til arbejdsgivere, der indgår en uddannelsesaftale med en voksen med voksenelevløn på områder med mangel på arbejdskraft (Beskæftigelsesministeriet 2008). Lønnen for voksenlærlinge ligger omkring $50 \%$ over lønnen for ordinære lærlinge. Det samlede antal voksne lærlinge steg til 6-8000 i perioden efter 1997 og omkring to tredjedele af dem er under ordningen med statstilskud. Godt en tredjedel af voksenlærlingene havde i forvejen en anden erhvervsuddannelse og andelen uden uddannelse ud over folkeskolen lå på $40 \%$. Andelen af voksenlærlinge udgør anslået $20 \%$ af samtlige lærlinge. Mange voksenlærlinge får reduktion i læretiden på grund af relevante arbejdserfaringer. Voksne over 25 år med arbejdserfaringer kan også få en realkompetencevurdering i forbindelse med grundlæggende voksenuddannelse (GVU) og derefter få en uddannelsesplan som angiver de kurser som skal gennemføres for at opnå status som faglært. GVU har haft en begrænset tilslutning (700 personer i 2006) blandt andet fordi det er en individuelt tilrettelagt uddannelse, som stiller krav til den enkelte om at fastholde uddannelsesplanen (EVA 2007). 


\section{Når tilbudet bestemmer hva man har behov for. Pleie- og omsorgssektoren som case}

Håkon Høst, NIFU Nordisk institutt for studier av innovasjon, forskning og utdanning

\subsection{Innledning}

Pleie- og omsorgssektoren er et særlig interessant case når det gjelder å belyse forholdet mellom arbeidslivets behov og utforming av yrkesutdanningene. I alle de nordiske land vil den store eldrebølgen gi samfunnene utfordringer det er vanskelig å fatte omfanget av når det gjelder behovet for pleiepersonell. Knapt for noen annen sektors del er det så bred enighet i samfunnet og politikken om at det er et stort behov kvalifisert arbeidskraft. Helsesektoren er i tillegg karakterisert ved et svært velutbygd system av yrker og yrkesutdanninger, som et uttrykk for arbeidslivets behov og hvordan dette søkes dekket. Det foregår en systematisk planlegging og vurdering av kompetansebehovene, og man har tatt i bruk omfattende prognosemodeller for å få fram tall på behovet for personell med ulike utdanninger. Det er tilsynelatende en sterk politisk vilje til styring av feltet for å kunne være rustet til de store kvalifikasjons- og rekrutteringsutfordringer pleie- og omsorgssektoren står overfor.

Til tross for et utgangspunkt som - sett fra privat sektor - må fortone seg et svært enkelt utgangspunkt for planlegging, så sliter man med å omsette behovene i en effektiv utdannings- og rekrutteringspolitikk. Dette skyldes ikke minst at forholdet mellom sektorens behov, utformingen av yrkesutdanninger er langt mer komplekst enn det kan synes på overflaten. Sektorens behov for arbeidskraft formidles i spenningene mellom ulike 
yrkes- og profesjonsgruppers interesser, sektormyndighetenes og utdanningsmyndighetenes interesser. I tillegg kommer søkernes interesser, som i vårt system betyr mye. Veletablerte og seige kulturelle mønstre i rekrutteringen, i kombinasjon med et stramt arbeidsmarked bidrar til både å påvirke rekrutterings- og kompetansepolitikken, og til å modifisere effekten av dem. Det viser seg vanskelig å få de utdanninger man etablerer til å rekruttere det personellet de etter planen skal. Dette gjelder spesielt yrkesutdanningene på nivået under sykepleierne. Politikerne vegrer seg, muligens av gode grunner, for å gå inn i det minefeltet som handler om å diskutere mer omfattende endringer i pleierutdanningenes oppbygning og struktur, og deres innbyrdes relasjoner. I stedet velger man å omdefinere personellbehovet i retning av de utdanningene man anser som mest realistisk å få økt søkning til. På denne måten blir det som til slutt defineres som rekrutteringsbehovet en størrelse bygget på svært mange og ulike premisser, ikke minst hva slags søkning en kan få gitt dagens strukturer.

Vi skal i denne artikkelen forsøke å beskrive og analysere de forhold, prosedyrer, aktører og interesser som påvirker definisjonen av behovene i arbeidsfeltet i pleie- og omsorgssektoren, og løsningene som etableres i utdanningssystemet. Utgangspunktet er situasjonen i Norge, men på tross av nasjonale ulikheter i utdanningssystemer og tradisjoner, er det mange fellestrekk mellom de nordiske land på dette området, ikke minst at feltet er dominert av voksne søkere (Høst 2006).

\subsection{Komplekse relasjoner i utdanning og arbeidsliv - noen teoretiske perspektiver}

Dominerende forestillinger om relasjonene mellom utdanning og arbeidsliv tar utgangspunkt $i$ at det finnes behov for en bestemt type kvalifikasjoner i arbeidslivet. Deretter gjelder det å raffinere utdanningstilbudet slik at dette behovet kan dekkes på en mest mulig effektiv måte, både kvalitativt og kvantitativt. Gjennom å bruke pleie- og omsorgssektoren som case skal vi her forsøke å illustrere en del av de forhold, mekanismer og aktører som bidrar til at formidlingen av arbeidslivets behov til utdanningssystemet i realiteten er en langt mer kompleks prosess. 
Pleie- og omsorgssektoren er et område i stor grad strukturert av yrker. Disse uttrykker det de fleste i dag oppfatter som arbeidslivets behov. Det finnes ulike teorier og modeller som har pretensjoner om å fortelle noe om hva som bidrar til utviklingen av yrker og yrkesutdanninger. Profesjonsteorier er ett inntak til å forstå dette. Selv om dette er vitenskapsbaserte teorier, avspeiler endringer i hva som har vært de dominerende teoriene også tidsperioder i den samfunnsmessige utvikling forøvrig. På det planleggingsoptimistiske 1950- og 60-tallet var det funksjonalistiske teorier som rådet grunnen. Profesjonelle yrkesutøvere ble sett nærmest som en naturlig refleks av arbeidslivets behov, og yrkesutdanning hadde som oppgave å sørge for reproduksjon av den profesjonelle standen, til alles beste (Halvorsen 1994). Senere ble disse teoriene kritisert for sin naivitet og kraftig modifisert. Under den mer langt kritiske fasen på 1970tallet, også samfunnspolitisk sett, overtok det såkalte maktperspektivet dominansen. Profesjonsteoriene vektla nå i større grad hvordan de profesjonelle selv formet og monopoliserte et arbeidsfelt, og hvordan de styrte utdanningene ut fra egne interesser. I tiårene som har gått har man vendt seg bort også fra dette mer kyniske perspektivet, og over mot teorier som er mer multidimensjonale; ulike forhold, aktører og relasjonene mellom disse anses nå å påvirke utformingen av profesjonelle arbeidsfelt og utdanningene til disse. Profesjonelle yrkesfelt vil være i stadig endring på grunn av styrkeforholdet mellom ulike profesjoner og yrker, mellom disse og staten, arbeidsgivere, brukere, markedet og andre utviklingstrekk.

Selv om profesjonsteoriene opplagt kan si noe også om yrker som ikke anses som profesjoner, vil det for mange av yrkesutdanningene på det vi kan kalle videregående opplærings nivå, være mer nærliggende å anvende et industrielt perspektiv. Den tyske sosiologen Ingri Drexel (1989) legger vekt på at etableringen av en arbeidstakerkategori er et resultat av en rekke forhold som må spille sammen. Sentrale aktører som utdannings- og sektormyndigheter, arbeidstakerorganisasjoner og arbeidsgivere, kanskje også brukere, må komme til enighet om at det er behov for en bestemt arbeidstakerkategori basert på et knippe kvalifikasjoner. Enighet om at det etableres en utdanning, eller opplæringsordning, vil være et første steg, men langt fra tilstrekkelig for at man skal lykkes i å etablere en ny arbeidstakerkategori. Om dette skal lykkes må den nye kategorien finne en plass i arbeidsdelingen, dvs. arbeidsgiverne må oppfatte at denne kategorien arbeidstakere 
løser deres problemer bedre enn alternative kategorier, og kategorien må aksepteres av tilgrensende arbeidstakerkategorier. Dessuten, og ikke minst, må den klare å etablere et rekrutteringsgrunnlag. Derfor må den tilby transparente karriereveier som er synlige og attraktive for ungdom eller andre søkere. Som regel vil det også være en betingelse at den nye arbeidstakergruppen etablerer en eller annen form for kollektiv ivaretaking av interesser. De prosesser som er beskrevet har er komplekse, og det er langt fra alltid at de lykkes og klarer å stabilisere produksjon og reproduksjon av en ny kategori. Drexel henter sin inspirasjon fra fagarbeidets Tyskland, men teorien dekker flere typer arbeidstakere enn rene fagarbeidere. I land eller områder der yrkesprinsippet står svakere, vil en sterkere grad av administrativ logikk kunne ligge bak utformingen av arbeidstakerkategorier, men også i slike tilfeller vil en være avhengig av mange av de beskrevne vilkårene. Når arbeidet organiseres i henhold til den enkelte bedrifts behov, vil det ikke danne grunnlag for en egen yrkesutdanning, men en større eller mindre grad av bedriftsintern opplæring. Opplæringen vil være mindre transportabel på tvers av bedrifter. Der det er mye opplæring vil arbeidstakerne knyttes sterkt til den enkelte bedrift. Der det er mindre opplæring vil arbeidskraften bli mer utskiftbar og flyktig. I slike arbeidsmarkeder er en bred grunnutdanning antatt å være det mest hensiktsmessige. Ulike land og ulike bransjer vil ha et varierende blandingsforhold mellom disse kvalifikasjonstypene, og det påvirker igjen hvordan arbeidslivets behov artikuleres til utdanningssystemet.

\subsection{Sektorens utvikling og utdanningenes særpreg}

Fordi den norske pleie- og omsorgssektoren er strukturert av yrker, vil det være interessant å se litt nærmere på hvordan de er oppstått, hva som særpreger dem, og på hvilken måte de uttrykker arbeidslivets behov.

Allerede på 1800-tallet ble de første sykepleierutdanningene etablert, da i tilknytning til sykehusene. Fremdeles var det store flertallet av pleiere ufaglærte, eller opplært gjennom arbeidet. Det var borgerskapets ugifte døtre som utgjorde pionerene, og et sentralt element i etableringen av sykepleierprofesjonen var sosial selektering (Melby 1990). Sykepleierne kjempet hardt for en lovfesting av tre års utdanning for å kunne kalle seg 
sykepleier. Et viktig ledd i denne kampen var å bekjempe forsøk på å etablere mer kortvarige pleierutdanninger på nivået under dem. Om dette var begrunnet i et ønske om å etablere en god sykepleierutdanning, rammet det likevel gruppene under, som tross alt utgjorde flertallet.

En av de store strategene bak utbyggingen av det nasjonale helsesystemet, helsedirektør Karl Evang, mente allerede på 1950-tallet at det ikke ville være umulig å realisere dette prosjektet, hvor første fase var sykehusutbygging, gjennom å bemanne pleierstillingene bare med sykepleiere. I tillegg til å være en markant lederskikkelse, representerte Evang også det man kan kalle «legestaten» (Erichsen 1996). I sterk konfrontasjon med Sykepleierforbundets holdning tok han initiativet til og lyktes med å få gjennomført etableringen av en kortere utdanning som hjelpepleier i 1963 (Høst 2006). Vi ser her et eksempel på at staten som aktør presser fram en ny utdanning basert på en annen definisjon av arbeidslivets behov enn den sykepleierne, som den dominerende yrkesgruppe hadde. Hjelpepleierutdanningen skulle vise seg å bli en suksess, og i løpet av få år var tusenvis av norske kvinner utdannet som hjelpepleiere, og i løpet av et par tiår var det titusener. Hjelpepleierne etablerte sin egen yrkesorganisasjon, som også vokste raskt.

Rekrutteringsgrunnlaget var kvinner fra lavere middelklasse og arbeiderklasse. Utdanningen skulle bli en av de vanligste utdanninger for kvinner i Norge på siste halvdel av 1900-tallet. Kanskje var det tidsriktigheten som var forklaringen til at utdanningen på kort tid ble såpass vellykket. Man ser lignende utviklingstrekk også i de andre nordiske land på denne tiden. Hjelpepleierutdanningen kan ses som uttrykk for en modernisering både av kvinnerollen gjennom å åpne muligheter for utdanning og yrke for kvinner som ville ut på arbeidsmarkedet, en modernisering av helsevesenet gjennom å differensiere yrkesstrukturen og øke andelen ansatte med en spesifikk yrkesutdanning, og til slutt en modernisering av utdanningssystemet gjennom å øke utbredelsen av yrkesutdanning til å omfatte et nytt område.

Hjelpepleierutdanningen var på 1960-tallet, som sykepleierutdanningen, et sektoransvar. Veien fra det offentlige helsevesenet til utdanningen var tett; arbeidsfeltets behov ble artikulert via sektormyndighetene direkte til utdanningen. Samtidig hadde sykepleierprofesjonen fra starten av sterk innflytelse og definisjonsmakt i denne prosessen. Sykepleierne satt i 
styrene for hjelpepleierskolene, arbeidet med læreplaner og var lærere. Gjennom dette sørget de for at utdanningen og arbeidsbeskrivelsene fikk en slik utforming at hjelpepleierne ikke beveget seg inn på deres jurisdiksjon. Rekrutteringen til hjelpepleierutdanningen skulle fra starten bli dominert av kvinner med til dels lang erfaring fra arbeidsfeltet og bidro således til å forsterke og befeste et allerede etablert mønster hvor rekrutteringen ikke gikk gjennom utdanning til arbeid, men via rekruttering av ufaglærte til arbeid, og deretter til utdanning (Høst 2006).

\subsection{Utdanningsmyndighetene overtar}

I løpet av 1960- og 70-tallet ble grunnlaget lagt for struktureringen av det norske utdanningssystemet $\mathrm{i}$ et videregående og et høyere utdanningsnivå. Den såkalte Bjørnsonkomitéen fikk i oppdrag å utrede innplasseringen av helse- og sosialutdanningene. Den anbefalte et trinnvist utdanningssystem, hvor hjelpepleierutdanningen utgjorde første del av sykepleierutdanningen. På denne måten ville man integrere de to rekrutterings- og utdanningstradisjonene i ett, felles system. Sykepleierforbundet opplevde imidlertid dette som en undergraving av deres profesjonaliseringsprosjekt. I allianse med andre profesjonsgrupper in spe fikk de i 1978 Stortingsflertallet til å avvise regjeringens anbefaling av en trinnvis utdanningsmodell. Dermed ble sykepleierutdanningen plassert på det nye høyskolenivået, og generell studiekompetanse, ikke lavere pleierutdanning, ble inngangskriteriet. Hjelpepleierutdanningen ble plassert i videregående opplæring, som ble et slags sidespor, uten meritterende betydning for videre pleierutdanning.

Gjennom etableringen av en felles videregående skole ble helsemyndighetenes sektoransvar for hjelpepleierutdanningen avviklet, og ansvaret overført til utdanningsmyndighetene. Deres dagsorden for videregående opplæring var på 1980- og 90-tallet ikke videreutvikling av utdanningene ut fra deres særgrunnlag, men tvert om standardisering. Målet var å bringe enhetsskolen enda et hakk videre som middel for å gi all ungdom lik rett og mulighet for mest mulig utdanning. Et enhetlig videregående utdanningssystem omfattende både allmenn- og yrkesfag skulle etableres. For yrkesutdanningenes del kom man etter hvert fram til at disse skulle formes rundt en felles mal med hensyn til kombinasjonen av allmenne fag 
og yrkesfag, og med et ønske at fleste mulig, eller alle yrkesutdanninger etter hvert skulle baseres på fagopplæring og lærlingordning. Et vesentlig element var at man ønsket å etablere det tradisjonelle gymnasets normalbiografi også for yrkesfagene, gjennom at elevene skulle starte på yrkesutdanning i en alder av 16 år og fullføre når de var 20. Argumenter om at dette ville kunne avskjære hjelpepleierutdanningen fra dens viktigste rekrutteringsgrunnlag, nemlig de litt eldre ungdommene og voksne, ble avvist som nærmest nostalgiske, eller til og med bakstreverske. I en fremtidsrettet utdanning måtte man basere seg på ungdom, ikke voksne. I motsatt fall ville man tape i kampen om rekrutteringen.

Den andre store endringen som traff pleie- og omsorgssektoren gjaldt målet om å legge alle yrkesutdanninger inn under fagopplæringssystemet. Igjen en generell politikk, men også her med en særegen begrunnelse rettet mot hjelpepleierutdanningen; Skulle man klare å rekruttere ungdom og også heve yrkets faglige posisjon og status, måtte man ta lærdom av de mannsdominerte håndverks- og industrifagene ${ }^{47}$ (Høst 2006). Derfor var lærlingordningen og fagopplæring viktig i seg selv. Resultatet ble et kompromiss; hjelpepleierutdanningen ble beholdt som en skolebasert utdanning med lange, innlagte praksisperioder, mens det ved siden av ble etablert en lærlingutdanning som omsorgsarbeider. Argumentet om lærlingordning var fundert i mulighetene til å heve fagområdets status, ikke måten arbeidslivets behov formidles til utdanningssystemet. Det var heller ikke begrunnet $i$ at det skulle lette overgangen fra skole til arbeid, fordi dette allerede fungerte utmerket $i$ hjelpepleierutdanningen. Deres lange praksisutplasseringen gjennom utdanningen bidro til å gi elevene tilknytning til og fotfeste i arbeidslivet.

${ }^{47}$ Se innstillingen fra Lyftingsmoutvalget 1986: Kvinner. 


\subsection{De kommunale pleie- og omsorgstjenestene vokser fram}

Hjelpepleiergruppen nærmet seg rundt 1980 sykepleierne i størrelse, og sykehus var det vanligste arbeidsstedet for begge grupper. Her var forholdet hjelpepleiere- sykepleiere 2:3 (Eilertsen 1989). I denne fasen skjedde det to ting som er viktig i forholdet mellom rekruttering og kompetanse. Sykepleierprofesjonen startet i denne situasjonen en offensiv for å ta tilbake den praktiske pleien med mål om å profesjonalisere hele pleiefeltet, nærmest etter mønster fra lærerne i skolen. Det første målet var at sykehuspleien, den som ble sett på som den faglig sett mest prestisjefylte delen av pleiefeltet, måtte bli bemannet med sykepleiere alene. De faglige argumentene var - som i dag - at kortere liggetid i sykehus, krevde mer intensiv og høykvalifisert pleie, og at den teknologiske utviklingen krevde pleiere med mer teoretisk utdanning i bunnen enn det hjelpepleierne hadde. Det asymmetriske styrkeforholdet mellom sykepleiergruppen og hjelpepleiergruppen, og argumentenes gjennomslag hos de som faktisk ansetter, stort sett sykepleiere, gjorde at utviklingen gikk mot en relativ rask marginalisering av hjelpepleiergruppen i sykehus. I 2010 er forholdet mellom hjelpepleiere og sykepleiere i sykehus ikke lengre 2:3, men 1:7.48 Hjelpepleierne er blitt en nesten usynlig gruppe i sykehus.

Et forhold som nok også bidro til at dette kunne skje uten mer oppstandelse var at etterspørselen etter hjelpepleiere totalt sett fortsatte å $ø$ ke. Den kommunale pleie- og omsorgssektoren ekspanderte voldsomt fra 1980 og utover og sysselsetter i dag langt flere enn sykehusene. Den omfatter i dag først og fremst pleieinstitusjoner for eldre, boliger for psykisk utviklingshemmede, og hjemmebaserte pleietjenester. I denne sektoren er bemanningssammensetningen helt annerledes enn i sykehus, ikke minst fordi det tradisjonelt er en langt mindre attraktiv del av helsesektoren. Her har således hjelpepleierne utgjort tyngdepunktet, sammen med såkalt ufaglærte, dvs. personell uten godkjent helsefaglig utdanning. Sykepleierne har utgjort under en fjerdedel.

48 SSB 2011. 


\subsection{Fra den mest populære yrkesutdanning til lavstatus på under 10 år}

Hjelpepleierutdanningen var på slutten av 1980-tallet den mest populære yrkesutdanningen i Norge med rundt 7000 søkere (Høst 2006). De aller fleste søkerne var voksne, knapt 1000 var ungdom slik utdanningssystemet i dag definerer det. Reform 94, med vekt på å gjøre dette til en ungdomsutdanning, ble ingen suksess. Mens de voksne mistet sine utdanningsmuligheter, appellerte verken hjelpepleierutdanningen eller det omsorgsarbeiderfaget til ungdom i tilstrekkelig grad til å erstatte det tidligere voksne rekrutteringsgrunnlaget. Av ungdom ble denne typen utdanning raskt stemplet som lavstatus. For arbeidsfeltet betød det at rekrutteringen av nyutdannede ble halvert (Høst 2004).

Det var imidlertid ikke lengre sektorens behov for en viss type arbeidskraft som sto i førersetet når utdanningsspørsmålene ble avgjort. Reform 94 var en utdanningsreform som fokuserte på ungdoms rett til utdanning. Den ga ikke bare ungdom rett til utdanning, men også til valg av utdanning. For fylkeskommunene var det innfrielse av disse rettighetene som ble det primære, både av juridiske og økonomiske årsaker. Vi ser altså en dreining fra å legge vekt på løsninger som bidrar til å kvalifisere pleiere for å dekke arbeidsfeltets definerte behov til en politikk som legger vekt på å tilfredsstille ungdoms rett til og etterspørsel etter utdanning. For rekrutteringen av faglærte til pleie og omsorgstjenestene i kommunene skapte dette store problemer.

Siden slutten på 1990-tallet begynte derfor de sentrale helsemyndighetene igjen å ta initiativ i rekrutteringspolitikken. Man lanserte handlingsplanen «Rett person på rett plass», som etter hvert kom til å befatte seg, ikke bare med tiltak for å rekruttere leger og sykepleiere, men i stadig større grad rekrutteringen av hjelpepleiere, omsorgsarbeidere og etter hvert helsefagarbeidere. Denne prioriteringen springer ut av bekymringer for rekrutteringen av basispersonell i pleietjenestene. Man har argumentert med det store behovet i de kommunale pleie- og omsorgstjenestene, men også lagt vekt på at det er behov for denne typen personell i sykehus. Det vil si man vurderer behovet ganske annerledes enn sykepleierprofesjonen gjør.

Gjennom «Rett person på rett plass» og oppfølgingen av denne gjennom kontinuerlige rekrutterings- og kompetanseplaner fra helsemyn- 
dighetene, har spørsmålet om rekruttering og utdanning av faglærte på nivået under sykepleiere blitt satt sentralt på dagsorden..$^{49}$ Kommunene har over en årrekke fått statlige tilskudd til utdanning og etterutdanning, som i stor grad har blitt benyttet på opplæringstiltak for voksne som allerede er ansatt i pleie- og omsorgstjenestene.

Denne politikken fikk i tillegg uventet hjelp av den såkalte Kompetansereformen i 2000 som lanserte nye grep og til dels nye midler for å sette i verk voksenopplæring. Egentlig var dette en reform presset fram av LO for å ivareta de voksne innenfor de tradisjonelle næringer som industri og håndverk. LO var bekymret for at yrkesutdanningen for de unge nå var blitt så god at de voksne sliterne ble hengende etter. Mens LOs medlemmer var lite fornøyd med reformen, ikke minst de dårlige økonomiske kompensasjonene for å delta i utdanningstiltak, var det kvinnene i helse og sosial som grep fatt i mulighetene. For dem åpnet Kompetansereformen åpning for en gjenåpning av de utdanningstiltakene Reform 94 hadde stengt.

Rekrutteringen av hjelpepleiere tok seg således opp igjen på begynnelsen av 2000-tallet, men det var altså voksne allerede ansatt i pleie- og omsorgsarbeid - og ikke ungdom - man rekrutterte til disse utdanningstiltakene.

\subsection{Utdanningsmyndighetene på banen}

Nesten 10 år etter at det negative utfallet for pleie- og omsorgsutdanningene i Reform 94 begynte å vise seg, har utdanningsmyndighetene begynt å aktivisere seg. Også de viser til det store arbeidskraftbehovet de demografiske endringene som følge av eldrebølgen vil skape innen pleie og omsorg, og man mener bestemt det er behov for pleiere på nivået under sykepleien. Sammenslåingen av hjelpepleiernes interesseorganisasjon, Norsk Helse- og Sosialforbund med de ufaglærtes organisasjon, Kommuneforbundet, i det nye Fagforbundet, la til rette for samling om å etablere en ny, felles utdanning som Helsefagarbeider. I den nye utdan-

${ }^{49}$ Sosial- og helsedirektoratet (2000): Rett person på rett plass. Handlingsplan for helse- og sosialpersonell. 
ningen ønsket man å ta det beste fra innholdet i hjelpepleierutdanningen og forene med lærlingordningen. På denne måten ville man skape en ny plattform for rekruttering av unge til pleie- og omsorg.

Det ble satset flere millioner kroner på en kampanje for å rekruttere ungdom til det nye helsearbeiderfaget. Det nye faget innebærer ikke noe kvalitativt nytt i sitt innhold. Det er utdanningsløpet som er endret fra tre år i skole med innlagt praksis, til to år i skole og to år som lærling. Meldingene ut til ungdom er at dette er et viktig og meningsfylt yrke hvor man får jobbe med mennesker i varierte settinger, og hvor arbeidskraftbehovet vil være uuttømmelig i fremtiden. Men indirekte gis det noen andre signaler: Posisjonen i arbeidsfeltet er den samme som tidligere, og i hvert fall ikke styrket, i sykehus kan man neppe regne med jobb. I den kommunale pleie- og omsorgssektoren venter små deltidsstillinger i ubekvemme skift. Heller ikke i utdanningsstrukturen er posisjonen bedret. Utdanningen er ikke meritterende på noe vis. Ikke får man godskrevet noe av utdanningen om man vil videre som sykepleier eller vernepleier, man kommer ikke engang inn på denne utdanningen uten at man først skifter over til studieforberedende program.

Resultatene er foreløpig ganske nedslående for den nye utdanningen. Søkningen til skoledelen av utdanningen er rimelig bra, med en viss økning sammenlignet med de to utdanningene helsearbeiderfaget erstatter. Men når elevene skal gå fra skole og ut i lære i pleie og omsorgstjenesten, velger de fleste i stedet å ta påbygning til studiekompetanse (Vibe m.fl. 2011). I den andre enden er det en økende andel som slutter underveis. Resultatet er at antall som fullfører yrkesutdanningen er gått klart ned, selv sammenlignet med de relativt lave tall fra før reformen.

For utdanningsmyndighetene skaper denne utviklingen store bekymringer. På den ene siden er økt gjennomføring og mindre frafall i yrkesutdanningen nå blitt en av deres absolutte hovedsaker. Det argumenteres for at man må ha fagbrev for å få jobb, også i pleie og omsorg. ${ }^{.0}$ Så lenge det i denne sektoren er en stor utfordring å fă tak i nok folk med utdanning, slår kanskje ikke dette argumentet så godt an. På den andre siden

${ }^{50}$ Kunnskapsminister Kristin Halvorsen i Klassekampen 20.11.2010. 
har man begynt å stille spørsmål ved om strukturen man har etablert $\mathrm{i}$ utdanningen egentlig passer på dette området. Hva betyr det at ungdom som velger denne utdanningen, stort sett ikke fullfører den, men enten hopper av eller går forbi?

Ikke bare er man bekymret for rekrutteringen av ungdom. Det viser seg at også muligheten for voksne ufaglærte for å kunne bli faglærte helsefagarbeidere er blitt mer problematisk under den nye utdanningen.

\subsection{Lærlingordning - hva slags endringer har det gitt?}

Etter at lærlingordningen og fagopplæring er innført også i helse- og omsorgssektoren, er det etablert et eget faglig råd for helse- og sosialfag. Ideelt sett skal man nå kunne justere for eksempel helsearbeiderfaget rent kvalitativt ut fra ut fra behovet i helsesektoren, fordi representanter fra sektoren, både på arbeidstaker og arbeidsgiversiden sitter i rådet og er forpliktet til å arbeide for dette. På samme måte skulle det kvantitative behovet i utdanningen kunne reguleres gjennom pleie- og omsorgstjenestenes inntak av lærlinger, noe som igjen skal gi signaler bakover i utdanningsstrukturen for å sikre en riktig dimensjonering av skoletilbudet.

Disse prosessene er imidlertid innrammet av forhold som har avgjørende betydning for utfallet. Læreplaner og kompetanseplattform er utformet på en måte som ikke skal utfordre etablerte yrkesgrenser. De åpner dermed i liten grad for å utvikle karrieremuligheter for helsefagarbeideren. Samtidig er det vanskelig å ikke komme i berøring med disse spørsmålene i arbeidet i dette faglige rådet. Et eksempel er adgangen til sykehusarbeid. I tråd med marginaliseringen av hjelpepleierne i sykehusene, opplever de fleste sykehusene det som lite naturlig å ta inn helsefagarbeiderlærlinger, enda mer når det totalt er snakk om stgnasjon, etter hvert nedgang i antall ansatte. Dette strider mot statens egen markedsføring av den nye utdanningen, hvor arbeid i sykehus har vært noe av det man har brukt for å få ungdom til å søke faget. Fordi fagforeningene til de faglærte har vanskelig for å nå fram med sine yrkesinteresser i arbeidsfeltet hvor sykepleierne dominerer, har de til en viss grad satset på en strategi hvor de forsøker å påvirke de sentrale helsemyndighetene til å gripe inn når det for eksempel gjelder rekruttering til sykehus. Sykehusenes motvilje har da også fått staten som sykehuseier til å gå lengre enn man van- 
ligvis opplever i å gi føringer når det gjelder bemanningssammensetning. I oppdragsbrevet til helseforetakene står det nå at disse skal ta inn lærlinger (Skålholt og Høst 2010). Noen helseforetak har fulgt opp dette, som oftest der de i tillegg har blitt utsatt for press og initiativer nedenfra. Dette har resultert i at en del helsefagarbeiderlærlinger har blitt tatt inn i sykehus for kortere eller lengre deler av læretiden, med større eller mindre grad av motvilje fra dem som til syvende og sist avgjør pleierbemanningen på den enkelte sykehusavdeling, nemlig sykepleierne. I en periode hvor sykehusene forventes å bemanne ned snarere enn opp, er det foreløpig lite som tyder på at lærlingene i særlig utstrekning blir tilbudt arbeid i sykehus etter at de har avlagt sitt fagbrev. Til syvende og sist ligger dette på den enkelte avdelingsleders vurdering av hva som er behovet i denne situasjonen. Og det er ikke å bryte med utviklingstrenden de siste 30 år, nemlig at man foretrekker flere fra sin egen yrkesgruppe når disse er tilgjengelige.

Når det gjelder den kvantitative reguleringen er utgangspunktet et stort rekrutteringsbehov i helse og sosial totalt, og i pleie- og omsorgstjenestene i særdeleshet. Likevel er det slik at kommunene i beskjeden grad etterspør lærlinger. En årsak kan være at stillingsstrukturen i pleie og omsorg, bygget på et omfattende system av deltidsstillinger, rett og slett ikke innbyr til å lage hele lærlingstillinger. Og hvorfor skulle de gjøre seg stor umake ved å utforme slike stillinger, når de etter all sannsynlighet likevel ikke får søkere. For hovedproblemet er at svært få unge ønsker seg en lærlingstilling i pleie og omsorg. Dermed er det også med fagopplæring i denne sektoren, til syvende og sist søkningen som avgjør rekrutteringen.

Lærlingordningen er en opplæringsordning primært tilpasset ungdom. Slik sett er det et paradoks at man valgte denne opplæringsordningen for et yrkesfelt som rekrutterer $80-90$ \% voksne. Dette må i stor grad tilskrives utdanningssystemets generelle innretning mot ungdom, som ikke bare gjør at systemet utformes med disse som utgangspunkt, men som også har bidratt til at utdanningsdiskursen er fullstendig dominert av denne måten å tenke på. Så selv om arbeidsfeltet faktisk rekrutterer nesten bare voksne, ses dette som en slags anomali som trolig vil forsvinne av seg selv, og i hvert fall når reservoaret av voksne som ønsker seg en yrkesutdanning er uttømt. Når feltet likevel fortsetter å rekruttere voksne, ufaglærte, fordi man ikke klarer å rekruttere lærlinger gjennom det som er tenkt som normalordningen, så eksisterer det faktisk ingen opplæringsordning for 
disse. I stedet henvises de til det som er fagopplæringens ordning for voksne som ikke har vært lærlinger; de må arbeide som ufaglærte i fem år før de har anledning til å framstille til en fagprøve. Foreløpig ser det ut til at dette vil bety en for rigid og lite attraktiv vei inn i helsearbeiderfaget til at man klarer å rekruttere et tilstrekkelig antall nye helsefagarbeidere.

\subsection{Kompetanseløftet}

Den siste av helsemyndighetens planer for kompetanseheving og rekruttering til pleie- og omsorgssektoren er Kompetanseløftet 2015. Dette er en ambisiøs satsing på kompetanseheving både kvalitativt og kvantitativt. Vi skal få både bedre og mer omsorg. I pleie- og omsorgssektoren er det i dag rundt 112000 årsverk i såkalt brukerrettet tjeneste. ${ }^{51}$ Fordi deltidsandelen er svært høy, er antall ansatte nesten 163 000. Grovt sett kan de sysselsatte deles inn i tre grupper ut fra utdanning;

- 25 \% høyskoleutdannede, regnet av årsverkene, mindre regnet som andel av de sysselsatte

- $40 \%$ med utdanning på videregående skoles nivå, hvor hjelpepleiere og omsorgsarbeidere er de dominerende

- $35 \%$ uten helse og sosialfaglig utdanning

I ulike offentlige dokumenter ${ }^{2}$ som behandler behovet for personell på kort og lang sikt, og som ligger som grunnlag for Kompetanseløftet 2015, drøfter man både behovet for flere hender og behovet for en kvalitativ bedre pleie. Det siste skal nås særlig gjennom satsing på en høyere utdannet arbeidsstokk inne pleie og omsorg. Selv om man ønsker en opprustning av kompetansen på alle nivåer i arbeidsorganisasjonen, mener man $\mathrm{i}$ tillegg at en endring i sammensetningen av pleiepersonalet, med en større andel med høyere utdanning, i seg selv vil gi bedre kvalitet. Fram til 2015

51 SSB sysselsettingsstatistikk for kommunene 2007.

52 Først og fremst St.meld. 25 (2005-2006). 
har man derfor satt som målsetting at de høyskoleutdannedes andel skal $\varnothing \mathrm{ke}$ fra 24 prosent (i 2005) til 34 prosent i $2015 .{ }^{53}$ For å få til dette vil man øke antall høyskoleutdannede i dobbelt så stort omfang som pleiepersonale på videregående nivå, mens andelen ufaglærte skal reduseres.

De videre prognosene lagt til grunn for planleggingen tilsier at de høyskoleutdannede før 2025 tar over som den største gruppen pleiere, og i antall fordobles innen 2030. Rekrutteringsstrategien er ikke bare begrunnet i den kvalitetsforbedring man antar vil følge av en slik endring i sammensetningen av pleiepersonalet. Den lave søkningen til ungdomsutdanningen på videregående nivå og den fortsatt relativt gode søkningen til pleierutdanningene på høyere nivå har også helt åpenbart spilt inn.

Signalet også her er imidlertid at det er viktigst å rekruttere sykepleiere, eller personell med høyere utdanning. Dette kan ses som et resultat, ikke bare av den direkte profesjonsinnflytelsen i definisjonen av behov, men indirekte, gjennom at det har festet seg en allmenn antakelse om at en større andel med et høyere utdanningsnivå vil bety økt behandlingskvalitet i pleietjenestene. Dette har intet empirisk grunnlag, men uttrykker den sterke tiltroen i vårt samfunn til teoretisk utdanning. Dermed blir det slik at målet om bedre kvalitet blir et mål om flere høyskoleutdannede, og det vil være vanskelig å si seg uenig i at vi skal ha bedre kvalitet. Problemene med å rekruttere ungdom til helsefagarbeiderutdanningen har også, paradoksalt nok, bidratt til at man nedjusterer behovet for denne gruppen. Mens helsefagarbeiderne i dag er den viktigste gruppen rent kvantitativt i de kommunale pleie- og omsorgstjenestene, er målet nå at de høyskoleutdannede, først og fremst sykepleiere, etter hvert skal være i flertall. Dette fordi man antar at det er lettere å rekruttere den siste gruppen, fordi det er flere søkere enn studieplasser på sykepleierutdanningen i dag.

Signalene om behov for helsefagarbeidere fra sektoren er derfor svært sprikende og preget av at de forhandles på rekke nivåer. På den ene siden signaliseres det at vi trenger helsefagarbeidere, og at de skal ansettes både i helseforetak og i pleie og omsorgstjenestene. På den andre siden trengs de når det kommer til stykket egentlig ikke i helseforetakene, og

${ }^{53}$ St.meld. 25 (2005-2006). 
også i pleie og omsorgstjenestene trengs helsefagarbeidere mest for å dekke behovet for flere hender. Økt kvalitet skal man i hovedsak sikre gjennom å øke andelen med høyere utdanning.

\subsection{Rekruttering av ufaglærte fortsatt viktigst}

Til tross for at profesjonene gjerne utvikler ambisjoner om å profesjonalisere, og slik sett også monopolisere hele arbeidsfeltet, er pleie- og omsorgsektoren svært arbeidskraftkrevende og har ekspandert i et tempo som har betinget en langt bredere rekruttering. Ikke bare har rekrutteringen av såkalte ufaglærte vært avgjørende rent historisk; også i dag er rekrutteringen «nedenfra» faktisk viktigere rent kvantitativt enn tilførselen av arbeidskraft fra det formelle utdanningssystemet (Aamodt m.fl. 2011). Dette er fordi de såkalt ufaglærte både fyller jobber man ikke klarer å fylle med utdannet personell, og samtidig utgjør det viktigste rekrutteringspotensiale for de som skal bli helsefagarbeidere. Utdanningssystemet bidrar således bare med høyskoleutdannede som altså utgjør en drøy fjerdedel av de ansatte, samt med en liten del av helsefagarbeiderne. Det er etablert noen relativt varige rekrutteringsmønstre, som på den ene siden har preget måten arbeidet organiseres og stillinger og stillingsprosenter utformes på, og på den andre siden hva slags rekrutteringsgrunnlag som etableres og vedlikeholdes i befolkningen. De ufaglærte har særlig vært kvinner, ofte godt voksne. I de senere år har dette blitt supplert med en sterkt økende andel innvandrere (Høst 2006, Aamodt m.fl. 2011). Et hovedmønster i rekrutteringen er at nye kommer inn via ekstravakter og små stillinger, for etter hvert å jobbe seg inn i større stillinger. Etter hvert får mange tilbud om ulike utdanningstiltak som kan føre dem fra den ufaglærte til den faglærte gruppen, tidligere hjelpepleier, nå helsefagarbeider.

Til tross for at man nærmest har forsøkt å utrydde dette rekrutteringsmønsteret, så fortsetter det å reprodusere seg selv. I 2009 ble det således rekruttert 34000 nye til den kommunale pleie- og omsorgsektoren, hvorav 220000 var ufaglærte.

Hvordan skal man så oppsummere dette store arbeidsfeltets behov for arbeidskraft og utformingen av yrkesutdanninger? 
Grunnlaget for hvordan behovene blir definert er lagt av den dominerende profesjonen, nemlig sykepleierne. I utgangspunktet mener de alt pleiearbeid må være profesjonelt og vitenskapelig basert, som de artikulerer det. I praksis har feltet ekspandert i et slikt tempo at det ikke har latt seg gjøre å bemanne det med bare høyskoleutdannet personell. Det er også et åpnet spørsmål om det hadde vært attraktivt for høyskoleutdannede å gjøre alle arbeidsoppgaver som ligger i det å pleie og stelle syke, eldre og pleietrengende.

I det store rommet sykepleierne etterlater seg i dette arbeidsfeltet, er det behov for mange titusener ansatte som kan ivareta de pleietrengende. I utgangspunktet ble dette feltet bemannet opp med ansatte uten forutgående utdanning, som så ble opplært gjennom arbeidet. Karl Evang var en pioner i arbeidet med å modernisere dette gjennom å sørge for at det ble opprettet en egen yrkesutdanning, som la grunnlaget for et nytt yrke, hjelpepleiere, mellom sykepleierne og de ufaglærte. Utformingen av den nye utdanningen ble ikke foretatt alene ut fra en form for objektiv studie av arbeidet, men vel så mye ut fra hvor mye utdanning man kunne gi disse pleierne uten at sykepleierne følte deres yrkesinteresser truet. Til tross for dette trange utgangspunktet ble hjelpepleierutdanningen en stor suksess. Men suksessen hvilte på at elevene ble rekruttert fra arbeidsfeltet for å gjennomgå denne utdanningen og statushevingen. I iveren etter å underlegge også denne utdanningen et moderne system for yrkesutdanning rettet mot ungdom, slo man samtidig ut barnet med badevannet. Fylkeskommunene, som etter Reform 94 hadde ansvaret for å gi ungdom rett til videregående opplæring, stengte ned de etablerte voksenutdanningene før man visste om den nye ungdomsutdanningen virket. For å kompensere på den nedgangen i rekruttering man fikk, har man prøvd ut ulike grep for å gjøre ungdomsutdanningene bedre og mer attraktive. Utgangspunktet er selvfølgelig det store rekrutteringsbehovet som venter oss i årene som kommer. Men ungdommen ser ut til å svare på hvert forsøk på nye reformer med å hoppe av og heller søke seg mot høyere utdanning. Selv de som i utgangspunktet har søkt seg til en videregående utdanning rettet mot å arbeide i helse og sosial, finner det tydeligvis ikke attraktivt å gå inn i arbeidsfeltet som helsefagarbeidere. Responsen på dette fra utdanningsog sektormyndighetene avtegner seg gradvis gjennom at det i praksis legges stadig økende vekt på rekruttering av personell med høyere utdan- 
ning. Dette bidrar til å svekke statusen til helsearbeiderfaget ytterligere. Dermed ender man mest trolig opp i å forsterke dagens rekrutteringsmønster; man rekrutterer en viss andel pleiepersonell gjennom høyere utdanning, mens de fleste fortsatt vil rekrutteres som ufaglærte.

Således er situasjonen blitt at måten arbeidslivets behov i første omgang formidles til det moderne utdanningssystemet på, i neste omgang skaper noen bestemte dynamikker og rekrutteringsmønstre, som i sin tur fører til en omdefinering av hva man egentlig trenger. For å si det litt enklere: Rekrutteringsbehovet defineres på grunnlag av det man får av søkere. Når man ikke får til ungdomsrekruttering til helsearbeiderfaget, så argumenterer man enda sterkere for behovet for sykepleiere og høyskoleutdannede. Alternativet med å gjenoppbygge gode voksenutdanninger ser ikke ut til å bli vurdert. Spørsmålet man må stille seg er om dette er en bærekraftig strategi. 


\section{Svensk lärlingsutbildning - förutsättningar och utmaningar $^{54}$}

Jonas Olofsson, Umeå Universitet och Eskil Wadensjö, Stockholms Universitet

\subsection{Ungdomarnas utbildning och utmaningar för samhällsekonomin}

De europeiska ekonomierna inklusive de nordiska länderna står inför stora utmaningar. För flera av dessa utmaningar har ungdomarnas ställning inom utbildning och arbetsmarknad en viktig roll. En viktig fråga är om åtgärder som riktas till ungdomar, speciellt utbildningen av dem, kan ha positiva effekter både för dem och för samhällsekonomin i stort. En sådan åtgärd, till vilken stora förhoppningar knyts bland annat i Sverige, är lärlingsutbildningen. Vi ska här i inledningen av detta kapitel behandla några av dessa utmaningar som utbildningen av ungdomar och då inte minst lärlingsutbildningen ställs inför.

De ekonomiskt mer utvecklade länderna i Europa, men också andra delar av världen, står inför en utmaning som ges av den demografiska utvecklingen. Andelen äldre ökar i befolkningarna och andelen i vad som vi brukar beteckna som aktiv ålder minskar. Försörjningsbördan ökar. Utveckling mot att varje person som är sysselsatt ska försörja fler för-

\footnotetext{
${ }^{54}$ Se Olofsson $(2005)$ och Olofsson och Wadensjö $(2006,2011)$ för mer detaljerade genomgångar av lärlingssystem.
} 
stärks av att ungdomar utbildas under fler år och att det i genomsnitt tar längre tid än tidigare innan de etablerar sig på arbetsmarknaden.

Olika åtgärder vidtas för att motverka effekterna av den demografiska utvecklingen. Mest uppmärksammade är försöken att höja utträdesåldern från arbetslivet genom förstärkta ekonomiska incitament för att arbeta vidare och höjningar av lägsta möjliga ålder vid vilken en pension kan tas ut. Andra åtgärder syftar till att öka det kvinnliga arbetslivsdeltagandet, öka antalet arbetade timmar genom att personer övergår från deltidsarbete till heltidsarbete, öka sysselsättningen för grupper med svårigheter att etablera sig på arbetsmarknaden som personer med funktionsnedsättningar och flyktinginvandrare, och öka arbetskraftsinvandringen. Av speciellt intresse här är åtgärder som syftar till att underlätta för ungdomar att tidigare komma ut i arbetslivet som lärlingsutbildning. Om ungdomar i genomsnitt kommer ut ett år tidigare i arbetslivet har det en effekt som svarar mot att den genomsnittliga åldern för utträde ur arbetslivet bland dem som är äldre senareläggs ett år.

En andra utmaning är att många ungdomar är arbetslösa även efter att de har blivit klara med sin utbildning. De har svårt att hitta ett första arbete som ger en ingång till arbetsmarknaden. Det gäller framför allt dem med kort utbildning. Lärlingsutbildning har i detta sammanhang framförts som en lösning. Det stora inslaget av arbetsplatsförlagd utbildning ger arbetslivserfarenhet och inte så få får en anställning på den arbetsplats de utbildats på.

En tredje utmaning är att ekonomierna ändras snabbt och med dem också arbetsmarknaderna och efterfrågan på olika typer av arbetskraft. Yrken som funnits länge krymper eller försvinner och arbetsställen reducerar personalstyrkan eller läggs ner. Sådana förändringar pekar på vikten av en bred utbildningsbas som gör det lätt att byta sektor och yrke. Frågan är om lärlingsutbildning kan bidra till att personer blir kvar i arbetslivet eller tvärtom om den låser in de med sådan utbildning i vissa yrken och sektorer. Ett kortsiktigt framgångsrikt inträde på arbetsmarknaden kan vara kombinerat med problem på längre sikt. Det leder till frågan om hur ungdomarnas utbildning ska utformas - är en bred gymnasieutbildning på sikt det bästa eller är mer snävt inriktade utbildningar som lärlingsutbildningar att föredra? Eller måste lärlingsutbildning kombineras med en garanti för vidareutbildning när det yrke lärlingarna ut- 
bildats för blir obsolet? I det senare fallet är det viktigt att institutioner på vuxenutbildningsområdet ger individer rikliga möjligheter till omskolning och omställning. Även kollektivavtal mellan parterna om omställningsstöd, så kallade omställningsavtal, kan vara viktiga för att underlätta individers möjligheter att välja ny riktning.

När vi nedan presenterar lärlingsutbildningen har vi hela tiden de här tre nämnda utmaningarna i åtanke.

\subsection{Lärlingsutbildningens historia och förutsättningar}

Vad är då lärlingsutbildning i våra dagar? Lärlingsutbildning förknippas ofta med ett äldre samhälle där anställningsrelationer och utbildningsvägar reglerades i lagar och rörligheten på arbetsmarknaden var liten. Hantverket styrdes av en skråordning som reglerade lärlingarnas och gesällernas villkor och kraven för mästarvärdighet. Politiken, som syftade till att vidmakthålla yrkeskunskaper och garantera social stabilitet, var en del av den merkantilistiska doktrinen att statsmakten skulle kontrollera och styra ekonomin. Marknaderna var strängt reglerade och den sociala maktoch statusordningen förankrad i juridiska regelverk. Lärlingsutbildningen har levt vidare som utbildningsmodell och social institution men skiljer sig avsevärt från den i äldre tider.

Intresset för lärlingsutbildning dikteras i mycket av önskemålet att unga ska slussas in på arbetsmarknaden i ordnade former och socialiseras in i en yrkesroll. Lärlingsutbildningen förväntas erbjuda kvalifikationer som mer omedelbart motsvarar de krav som ställs i arbetslivet. Men bakom strävandena efter att uppmuntra lärlingsutbildning finns också en önskan att skapa alternativa utbildningsvägar för ungdomar som inte är intresserade av skolförlagda studier och som ofta kommer från mindre privilegierade familjeförhållanden. Via lärlingsutbildningen kan en yrkesidentitet med betydelse för mognadsprocessen och individens oberoende utvecklas.

Lärlingsutbildningen skiljer sig åt mellan olika länder. Inom Norden har lärlingsutbildningen en stark ställning i Danmark och Norge men en relativt svag ställning i Sverige. En grundläggande fråga när vi behandlar lärlingsutbildningens förutsättningar är i vilken utsträckning utbild- 
ningsmodellen bidrar till att möta krav som arbetsmarknaden ställer på rörlighet, kvalifikationer och anställningsbarhet. Det är naturligtvis svårt att säga hur förutsättningarna och kraven utvecklas på arbetsmarknaden $\mathrm{i}$ ett längre perspektiv, mer än att yrkesutbildning på grundläggande och mer kvalificerad nivå ter sig allt viktigare för möjligheterna att få goda och utvecklande arbeten. ${ }^{55}$ Däremot kan vi urskilja några tydliga utmaningar i det korta och medellånga perspektivet.

\subsubsection{Flexicurity}

På europeisk nivå har diskussionerna om villkoren $\mathrm{i}$ arbetslivet på senare år i hög grad präglats av föreställningarna bakom flexicurity, märkbart påverkade av de danska strävandena efter att utforma en arbetsmarknadspolitisk modell som förenar kraven på flexibilitet med löntagares rätt till inkomsttrygghet och kompetensutveckling. Det som kännetecknat modellen är å ena sidan ett svagt anställningsskydd och å andra sidan en arbetsmarknadspolitik präglad av omfattande utbildningsinsatser och en relativt generös och framför allt tidsmässigt utsträckt inkomstbortfallsersättning.

Kritiken mot flexicurity-modellen har emellertid tilltagit på senare år. Det har påtalats att inkomstbortfallsersättningen i många länder, inklusive Sverige och Danmark, ger otillräckligt skydd för genomsnittliga inkomsttagare. Det ökar intresset för avtalade och privata lösningar vid sidan av den allmänna arbetslöshetsförsäkringen. Ett annat problem är att risken för stora inkomstminskningar vid arbetslöshet kan leda till att specialiserade investeringar i yrkeskunskap upplevs vara riskabla. Benägenheten att delta i yrkesutbildning minskar med negativa följder för dynamiken i arbetslivet och effektiviteten i samhällsekonomin i stort.

Kritik kan också riktas mot att otrygga anställningsvillkor minskar både anställdas och arbetsgivares benägenhet till effektivitetshöjande utbildningssatsningar. I förlängningen leder det till en arbetsmarknad som har stor flexibilitet när det gäller anpassningen av antalet sysselsatta och arbetade timmar, men som inte stärker förmågan till omställning och förnyelse.

55 Se Skill needs in Europe (2008). 
Lagstadgat anställningsskydd och turordningsregler vid uppsägning kan göra arbetsgivare mer benägna att satsa på anställdas kompetensutveckling och ta ansvar för ungas utbildning i lärlingsliknande former. På motsvarande sätt kan ett omfattande utnyttjande av korttidsanställningar och arbetskraftsrekrytering via bemanningsföretag innebära att intresset för att erbjuda kompetensutveckling minskar. Dessutom finns en risk att företagen strävar efter att förkorta upplärningstiderna för olika arbetsmoment, vilket kan urholka jobbens kvalitet, om de i hög grad förlitar sig på tillfälligt rekryterad eller inhyrd arbetskraft.

\subsubsection{Mobication}

Mot bakgrund av den sistnämnda kritiken har det presenterats förslag på en ny arbetsmarknadspolitisk modell kännetecknad av en starkare inriktning på omställningsförmåga (rörlighet/mobility) och utbildning (education). Mobication har använts som benämning av modellen. ${ }^{56}$ En viktig utgångspunkt är förebyggande arbetsmarknadspolitik, där gränsen mellan arbetsmarknadspolitik och utbildningspolitik suddas ut. Insatserna ska inriktas på hela befolkningen och inte enbart på arbetslösa. Traditionella utbildnings- och arbetsmarknadspolitiska insatser som yrkeskurser och inkomststöd ska kompletteras med ett flexibelt och vittomfattande utbildningssystem som gör kontinuerligt lärande möjligt. På så sätt ska funktionell rörlighet (functional mobility) på arbetsmarknaden - rörligheten mellan olika jobb och mellan jobb och utbildning samt tillbaka till jobb - underlättas. Funktionell rörlighet förekommer alltid i stor omfattning på arbetsmarknaden via jobbyten. Dessutom ska övergångsrörligheten (transitional mobility) bli effektivare. De som har stått utanför arbetslivet under en längre period ska få ett effektivare utbildningsstöd för att kunna etablera sig på arbetsmarknaden. Övergångsrörligheten avser dels unga och nya invandrare, dels återinträdande på arbetsmarknaden som långtidssjuka.

${ }^{56}$ Se 2009 EU-China High Level Round Table on Social Security (2009) samt Andersen (2010). 


\subsubsection{Matchningen}

I perspektiv av de flöden och matchningsprocesser som kännetecknar arbetsmarknaden behövs ett flexibelt utbildningssystem för både utbildning av unga och livslångt lärandet. I Sverige byter mer än var tionde sysselsatt arbete varje år. ${ }^{57}$ Andelen fluktuerar något med konjunkturen. Jobbyten är mest förekommande i yngre åldrar och varierar mellan regioner och lokala arbetsmarknader beroende på näringsstruktur. Till detta kommer att mellan 5 och 7 procent av arbetskraften lämnar sysselsättningen varje år, till exempel genom ålderspensionering. Samtidigt tillkommer ungefär lika många. Det handlar framför allt om unga och nya invandrare men också personer som varit utanför arbetskraften en tid av olika skäl. Sammantaget betyder det att ungefär en femtedel av de sysselsatta är nya på sitt jobb sett från ett år till ett annat. Ur ett effektivitetsperspektiv är det viktigt att dessa flöden och matchningsprocesser fungerar så friktionsfritt som möjligt. Annars får arbetsgivare inte arbetskraft med de kvalifikationer de efterfrågar när de anställer. För individen innebär en försämrad matchning på arbetsmarknaden mer begränsade valmöjligheter, osäkrare inkomstförhållanden och försämrad välfärd.

Matchningen måste också relateras till utbildningskraven. En OECDstudie om flöden och jobbyten på arbetsmarknaden som täcker ett stort antal länder inklusive Sverige, visar att utbildningsnivå tillsammans med ålder och kön förklarar mycket av skillnaderna mellan individer vad gäller uppsägningar och anställningar. ${ }^{58}$ De som saknar yrkesutbildning är överrepresenterade bland de uppsagda. Samtidigt räcker det inte att bara se på utbildningsnivå. Äldres möjligheter att konkurrera om arbeten kan begränsas av att de har föråldrade utbildningar, även om deras utbildning formellt är hög. De äldres möjligheter att konkurrera om lediga arbeten med yngre och nyutbildad arbetskraft kan förbättras om de får del av fortlöpande kompetensutveckling. Lärande inom sitt eget och nya yrkesområden vidgar frihetsgraderna på arbetsmarknaden, minskar ohälsosam inlåsning och underlättar matchningsprocessen.

${ }^{57}$ Se Andersson (2010) samt SCB (2010).

58 Se Bassini och Marianna (2009). 
I Sverige talar idag mycket för att matchningseffektiviteten har avtagit. Företagen uppger att de har svårigheter att rekrytera nya medarbetare med rätt kompetensprofil, trots en relativt hög arbetslöshet. Beveridgekurvan som anger sambandet mellan arbetslösheten och lediga platser har flyttats utåt; för varje given nivå på antalet lediga platser är arbetslösheten högre. De privata arbetsgivarnas huvudorganisation Svenskt Näringsliv har i återkommande enkäter avseende företagens rekryteringsarbete visat att omkring en femtedel av alla rekryteringar ställs in på grund av att man inte kan hitta sökande med rätt utbildningsbakgrund. ${ }^{59}$ Det illustrerar tydligt problemen inom arbetsmarknads- och utbildningspolitiken, problem som förstärks av den pågående generationsväxlingen på arbetsmarknaden. Under de kommande 15 åren pensioneras 250000 fler än under den föregående 15-årsperioden. Samtidigt minskar inflödet på arbetsmarknaden påtagligt genom att antalet individer i åldersgruppen 20-25 år sjunker med närmare 20 procent fram till 2020.

Lärlingsutbildningen, som förutsätter ett starkare utbildningsengagemang i arbetslivet, är väsentlig i sammanhanget. Företag och offentliga verksamheter måste vara beredda att utbilda sin egen och tillkommande arbetskraft. Det förutsätter ett närmande mellan utbildningsinstitutioner och arbetsliv eller effektiva system för att sprida ansvaret och kostnaderna för utbildning och kompetensutveckling mellan det offentliga, arbetsmarknadens parter och dem som deltar i utbildning. Regleringen och kvalitetssäkringen av utbildningen, liksom formerna för samråd mellan de parter som ansvarar för utbildningen, blir därmed en strategisk fråga för lärlingsutbildningen.

${ }^{59}$ Se Att söka men inte finna (2010). 


\subsection{Lärlingsutbildningens betydelse - en fördjupning}

Lärlingsutbildningen måste skiljas från rent skolförlagd yrkesutbildning och sedvanlig praktik på en arbetsplats. I sentida översikter om lärlingsutbildning hänvisas ofta till en definition av den brittiske forskaren Paul Ryan, en av de främsta experterna på lärlingsutbildning (Ryan 1998).60 Han definierar lärlingsutbildning som en strukturerad utbildning med huvudfokus på arbetslivet. Utbildningen innehåller en bestämd blandning av utbildning på en arbetsplats och skolförlagda allmänteoretiska och yrkesteoretiska moment. Utbildningen leder till formellt erkända yrkeskvalifikationer som ger lärlingen omedelbart tillträde till ett särskilt yrkesområde. Arbetsgivare är med och finansierar utbildningen och lärlingen får i allmänhet någon slags ersättning under lärlingsutbildningen. Paul Ryan lägger till att lärlingsutbildningen, i de länder där den är mest utvecklad och utbredd, oftast utgör en integrerad del av utbildningssystemet på gymnasial nivå.

Samtidigt medger Paul Ryan att det inte alltid är alldeles lätt att urskilja vad som ska klassas som lärlingsutbildning. I flera länder, t.ex. i Sverige, innehåller den skolförlagda yrkesutbildningen också arbetsplatsförlagt lärande. ${ }^{61}$ Men det som skiljer dessa utbildningsmoment från egentlig lärlingsutbildning är att praktik inom ramen för en skolförlagd yrkesutbildning i allmänhet utgör en mindre del av den totala utbildningstiden och att lärandeinnehållet inte heller är lika genomarbetat som i en lärlingsutbildning. Den skolförlagda utbildningen uppfattas oftast som en förberedande utbildning som förutsätter kompletterande färdigutbildning på arbetsplatser. Dessutom saknas i allmänhet möjligheter till ett anställningsförhållande under praktikperioderna.

Det finns många fördelar med lärlingsutbildning jämfört med en yrkesutbildning som huvudsakligen genomförs i skolor. ${ }^{62}$ För det första förutsätter lärlingsutbildningen att arbetsgivare ställer utbildningsplatser till förfo-

\footnotetext{
60 Ryan (1998).

61 Beteckningen arbetsplatsförlagt lärande (APL) har ersatt uttrycket arbetsplatsförlagd utbildning (APU) inom gymnasieskolans yrkesprogram.

62 Se t.ex. OECD (1994) \& OECD (2009).
} 
gande. Det senare utgör en garanti för att utbildningen orienteras mot områden på arbetsmarknaden där det finns en efterfrågan på arbetskraft. I en skolförlagd utbildningsmodell där elevernas egna val i högre grad ska styra sammansättningen av utbildningsplatser finns inga motsvarande garantier.

För det andra är arbetsplatserna en stark lärandemiljö. Eleverna får använda den senaste utrustningen och får en insyn i arbetets organisering. Det innebär att man tillägnar sig både "hårda" och "mjuka" kvalifikationer på ett sätt som är omöjligt i en artificiell utbildningsmiljö. Skolorna har sällan förutsättningar att erbjuda elever möjligheter att använda den senaste tekniken eller att få insyn i de senaste arbetsprocesserna, vilket också understryker betydelsen av mer omfattande arbetsplatsförlagda inslag i utbildningen.

För det tredje underlättar lärlingsutbildningen rekryteringen av arbetskraft. För en arbetsgivare är nyrekrytering förenat med betydande osäkerhet och stora kostnader. Det handlar om att få en bild av personens arbetsförmåga och pålitlighet, givet de olika krav och påfrestningar som kan uppstå på en arbetsplats och inom ett särskilt yrke. Lärlingsutbildningen ger arbetsgivaren mer gynnsamma möjligheter att pröva en individs arbetsförmåga, men naturligtvis också - som framhölls tidigare - att utrusta individen med de kvalifikationer som är särskilt önskvärda inom det aktuella företaget.

För det fjärde bidrar lärlingarna till produktionen. Det här möjliggör ett tillskott för de inbladade företagen och för samhällsekonomin i stort, liksom för de enskilda eleverna i den mån lärlingarna får en ersättning under utbildningstiden. Värdet av lärlingarnas tillskott ökar över tid i takt med att kvalifikationerna utvecklas och att lärlingarna kan anförtros mer avancerade arbetsuppgifter.

Ur lärandesynpunkt är arbetsplatserna väsentliga för att levandegöra de teorier som förmedlas i skolundervisningen, för att utveckla problemlösningsförmågan kopplat till verklighetsnära omgivningar och för att fördjupa elevernas tekniska och sociala kompetens.

I teorin finns det alltså starka argument för att en yrkesutbildning med betydande inslag av arbetsplatsförlagt lärande, enligt lärlingsutbildningsmodellen, har en rad företrädanden jämfört med en huvudsakligen skolförlagd yrkesutbildning. Intresset för lärlingsutbildningsmodellen har också varit stort på senare år därför att jämförelser av ungdomsarbetslös- 
het och sysselsättning i olika länder illustrerar att ungas arbetsmarknadsetablering tycks fungera effektivare i länder med utbredd lärlingsutbildning. Det har också hävdats att lärlingsutbildningen bör vara särskilt attraktiv i länder med ett långtgående anställningsskydd och begränsade löneskillnader. Med sådana villkor på arbetsmarknaden blir rekryteringen av ny arbetskraft en mer grannlaga process jämfört med länder där anställningstryggheten är mindre och ungas relativlöner lägre. Givet att anställningsförfarandet framstår som ett större och mer långsiktigt åtagande kan en lärlingsutbildning fungera som en effektiv metod för arbetsgivare att urskilja den arbetskraft som man önskar att knyta till företaget.

Men det har också betonats att det inte finns några enkla medel för att föra över en utbildningsmodell som fungerar i ett land till ett annat land med andra förutsättningar och andra traditioner. Det framhålls att lärlingsutbildningen grundar sig på specifika institutionella förutsättningar och regleringar, särskilt kopplat till villkoren på arbetsmarknaden. ${ }^{63}$ Dessa förutsättningar varierar i hög grad mellan länderna, vilket också gör att lärlingsutbildningen fungerar olika. Den danska och tyska lärlingsutbildningen är t.ex. organiserad på olika sätt, den tyska enligt ett dualt system och den danska enligt en växelutbildningsmodell, men båda modellerna bottnar i hög grad i ett utvecklat system för generellt erkända yrkeskvalifikationer på arbetsmarknaden. Detta system får konsekvenser för rekryteringen av arbetskraft till olika yrken och ger yrkesutbildningen en helt strategisk roll i sammanhanget. Systemet baseras både på lagstiftning och kollektiva överenskommelser mellan arbetsmarknadens parter. I Sverige finns också regler kring yrkeslegitimationer, men de är inte alls lika utbredda på arbetsmarknaden. Uppdelningen mellan yrkeslärd och icke facklärd arbetskraft har inte haft samma betydelse på svensk arbetsmarknad som i länderna med starka lärlingsutbildningssystem.

Det finns också spänningar inbyggda i ett lärlingsutbildningssystem, som riskerar att göra utbildningen mindre fruktbar för de deltagande individerna och mindre effektiv ur ett bredare samhällsperspektiv. Enskilda arbetsgivare, som erbjuder utbildningsplatser inom lärlingsutbild-

${ }^{63}$ Soskice (1994) \& Ryan (2003). 
ningens ram, har ett naturligt intresse av att prägla utbildningens innehåll efter företagets behov samtidigt som syftet med utbildningen bör vara att erbjuda en så bred yrkeskompetens som möjligt, dvs. yrkeskvalifikationer som är användbara på olika delar av arbetsmarknaden. Men det finns också en risk att en mindre målmedveten och välstrukturerad arbetsplatsförläggning inom yrkesutbildningens ram kan fungera som en källa till besparingar för de berörda skolorna. Utbildningstid och utbildningsansvar förs över från skolor till arbetsplatser utan motsvarande överföring av resurser och utan avseende vid hur utbildningstiden på arbetsplatserna ska berika yrkesutbildningen i stort.

Båda exemplen talar för behovet av en reglering av lärlingsutbildningen så att den inte reduceras till en allt för snäv och företagsanpassad utbildning eller till en metod för att möjliggöra besparingar och ökad lönsamhet i enskilda skolor, på bekostnad av enskilda elevers lärande. Om lärlingsutbildningen ska fungera som en kvalificerad utbildning och inte som en förvaring utan lärandeambitioner krävs således att tydliga kvalitetskriterier och lärandemål utvecklas. Dessa kriterier och mål måste i sin tur förankras i institutioner som omfattar såväl de berörda skolorna och arbetsplatserna som lärlingarna. Internationella erfarenheter talar för att den sociala regleringen av lärlingsutbildningen är central. Parterna på arbetsmarknaden spelar en särskilt viktig roll för att dels garantera att utbildningen ges ett högkvalitativt och uppdaterat innehåll, och dels att utbildningen är likvärdig oberoende av var utbildningen ges. ${ }^{64}$

${ }^{64}$ Se SOU 2010:75 bilaga 4. 


\subsection{Lärlingsutbildningen och arbetsmarknadens reglering 65}

En förklaring till det stora intresset för lärlingsutbildning är således att den förväntas underlätta övergången från skola till arbetsliv. Övergångsfasen är ofta problemfylld. Arbetsmarknaden är inte en marknad där utbud och efterfrågan hela tiden möts och lönen sätts så att alla som vill ha ett arbete får det och att det inte finns några lediga arbeten som det inte går att finna arbetskraft till. Arbetsmarknaden kännetecknas tvärtom av långa kontrakt. Merparten är länge på samma arbetsplats och mycket av anpassningen till förändringar av såväl efterfrågan som utbud sker på arbetsplatserna. De företagsinterna arbetsmarknaderna är mycket viktiga. Den anpassning till förändringar i utbud och efterfrågan som sker på den externa arbetsmarknaden tar tid och det finns samtidigt både arbetslösa och lediga platser.

Att merparten har långa anställningar innebär också att en stor del av arbetskraften i praktiken inte är aktiv på den externa arbetsmarknaden. Det finns visserligen som framgått ovan många som under ett år frivilligt lämnar ett arbete för ett nytt och bättre och många som av olika anledningar ofrivilligt förlorar sitt arbete, men de utgör inte merparten av dem som har ett arbete.

Ungdomar söker arbete på den öppna arbetsmarknaden mycket oftare än andra åldersgrupper, då de ofta är nyinträdande på arbetsmarknaden. De ungdomar som har arbete är ofta bland de sist anställda på arbetsplatsen. Det innebär att de löper en större risk än äldre att förlora arbetet om arbetsplatsen vill minska antalet anställda. Ibland är det en direkt följd av anställningsformen - visstidsanställningar eller provanställningar är vanliga bland ungdomar - men i andra fall följer det av senioritetsregler. Att vara ny på arbetsmarknaden innebär också att sakna eller ha mindre arbetslivserfarenhet. Arbetslivserfarenhet är viktig när det gäller att få ett arbete i konkurrens med andra. Att unga ofta saknar arbetslivserfarenhet eller endast har kort sådan gör det svårare för arbetsgivaren att bedöma deras förmåga.

${ }^{65}$ För mer om ungdomens arbetsmarknad i Sverige, se till exempel Schröder (1991) och SCB (2009). 
Arbetsmarknaden påverkas av den institutionella ramen. Institutionella element kombineras på olika sätt i olika länder och under olika perioder. Arbetsmarknadernas parter, inte minst fackföreningarna, är viktiga. De kan genom kollektivavtal påverka lönesättningen, bland annat genom avtal om minimilöner, men också hur utbildningen organiseras i företagen.

Höga minimilöner gör att ungdomar făr starka incitament att utbilda sig vidare - att tidigt gå ut i arbetslivet blir inte attraktivt. Det innebär också att företagen investerar i utrustning och teknik som inte förutsätter lågavlönad okvalificerad arbetskraft. När väl sådana investeringar är gjorda, är det inte lönsamt för företagen att anställa ungdomar utan yrkeskvalifikationer, även om lönekostnaderna för att anställa dem tillfälligt skulle sänkas, till exempel genom statliga lönesubventioner.

Den statliga regleringen är betydelsefull på flera områden. Ett exempel är lagar som reglerar uppsägningar. De kan göra det dyrare att säga upp personer och därmed blir det indirekt dyrare att anställa någon. Ungdomarna kan i så fall få större svårigheter att hitta ett arbete. Också legitimationskrav och utbildningskrav vid utövandet av olika yrken är viktiga. Sådana regler kan begränsa den arbetsmarknad där ungdomar utan yrkesutbildning kan få arbete.

Inte minst viktigt för ungdomarna är hur utbildningssystemet är uppbyggt - både den utbildning som sker i skolform och den som sker ute på arbetsplatserna. Utbildning i skolform kan i högre eller lägre utsträckning förbereda för arbetsmarknaden, och lärlingsutbildningens dimensionering och inriktning kan vara mer eller mindre anpassad till efterfrågan på arbetsmarknaden. De olika elementen kan kombineras till olika "regimer" vad gäller konstruktionen av ungdomarnas arbetsmarknad. Nedan presenterar vi ett par sådana regimer eller ansatser.

Den första ansatsen betonar arbetsmarknadens duala karaktär och belyser skillnader mellan den primära arbetsmarknaden, som består av interna arbetsmarknader, och den sekundära arbetsmarknaden. De interna arbetsmarknaderna präglas av att anställningsvillkor, löner och utvecklingsmöjligheter är goda. Hit rekryteras personal som arbetsgivarna är intresserade av att behålla under längre tidsperioder. De är beredda att investera långsiktigt i personalens kompetens och erbjuder olika sociala förmåner i syfte att skapa trivsel, trygghet och högre effektivitet. På den sekundära arbetsmarknaden råder andra förhållanden. Den präglas av 
osäkra anställningsförhållanden och tidsbegränsade anställningar. Lönerna är i allmänhet låga och med anställningen följer inte samma sociala förmåner som på den primära arbetsmarknaden. De som befinner sig på den sekundära arbetsmarknaden har ofta en svagare förankring i närmiljön och saknar anknytning till etablerade sociala nätverk. Hit hör ofta lågutbildade, utrikes födda och unga nyinträdande på arbetsmarknaden. Termerna insiders och outsiders används ofta för att beskriva villkoren på de olika arbetsmarknadssegmenten. Insiders är etablerade på interna arbetsmarknader och har goda villkor medan outsiders konkurrerar om mindre kvalificerade jobb på den sekundära arbetsmarknaden. USA uppvisar ett tydligt dualt arbetsmarknadsmönster med primära och sekundära arbetsmarknader.

En andra ansats betonar förekomsten av yrkesbaserade arbetsmarknader. Här går segmenteringen av arbetsmarknaden efter yrkeslinjer snarare än efter uppdelningen i interna och sekundära arbetsmarknadssegment. Villkoren för arbetskraften bestäms av tillträdet till olika yrken och villkoren förknippade med dessa yrken. Yrkesinriktad utbildning är en förutsättning för tillträde. Bundenheten till en enskild arbetsgivare är lägre än vad den är på interna arbetsmarknader, eftersom yrkesutbildningen och villkoren för anställning $i$ högre grad är reglerade via avtal och lagstiftning än via informella band till en viss arbetsgivare. Tyskland är ett ofta anfört exempel på en starkt yrkesbaserad arbetsmarknad.

På de interna arbetsmarknaderna spelar företagsspecifik kompetens en större roll. Den enskilda arbetstagarens kompetens är mindre värdefull utanför företaget, vilket ger starka incitament att stanna länge på samma arbetsplats. På en arbetsmarknad som är segmenterad efter yrkeslinjer är kompetensen mindre beroende av det enskilda företaget. Yrkesrollen baseras på kunskaper och färdigheter som byggs upp via en lärlingsutbildning riktad till olika delar av arbetsmarknaden. Skillnaderna i anställningsvillkor är mindre, eftersom löner och anställningsförhållanden i hög grad regleras via kollektivavtal. I länder med utpräglat yrkesbaserade arbetsmarknader är i allmänhet partsorganisationerna starka, vilket bidrar till att förhindra framväxten av sekundära arbetsmarknadssegment präglade av låga löner och låg produktivitet. 


\subsection{Internationella erfarenheter 66}

Arbetsmarknadsmodellerna och segmenteringsmönstren kan kopplas till olika utbildningssystem. På en arbetsmarknad reglerad efter yrkeslinjer spelar lärlings- och yrkesutbildningen en framträdande roll både för företagens rekrytering och enskilda individers etablering i arbetslivet. På en arbetsmarknad som är präglad av en uppdelning mellan interna arbetsmarknader och en sekundär arbetsmarknad har lärlingsutbildningen inte samma centrala betydelse. Yrkesutbildning, såväl skolbaserad som arbetslivsförlagd, har mindre betydelse än allmänteoretisk och medborgerligt inriktad utbildning i Storbritannien och USA. Detta gäller särskilt den utbildning som erbjuds på gymnasial nivå. I Schweiz, Tyskland och Österrike har däremot lärlingsutbildningen sedan länge haft en mycket stark ställning.67 Det gäller också Danmark och Norge.

I Sverige har den dominerande uppfattningen varit att gymnasieutbildningen inklusive yrkesutbildningen i första hand ska ge ungdomar allmänteoretiska kunskaper nödvändiga för att klara medborgarrollen och livet vid sidan av arbetslivet och ge en bas för fortsatt utbildning. Denna tradition betonar yrkesutbildningens betydelse för individens möjligheter att göra egna val. ${ }^{68}$

Frågan är då vilken betydelse yrkesutbildningen har för ungdomars etableringsmöjligheter. Många internationellt jämförande studier pekar på positiva effekter av en reglerad och arbetslivsanknuten utbildning. Lärlings- och yrkesutbildning tycks bidra till att reducera arbetslöshetsrisken och minska sannolikheten för att unga ska träda in på arbetsmarknaden utan någon utbildning utöver grundskolenivå. Yrkesutbildningens positiva effekter tycks vara mest markant i länder där den är orienterad mot ett yrke och utformad i nära samverkan mellan skola och arbetsliv.

Flera studier, bland annat en av Wolfgang Lehman (2005), pekar på dåliga resultat av yrkesutbildning i länder med mera liberala arbetsmark-

\footnotetext{
${ }^{66}$ Ett par internationella jämförelser är Ashton och Green (1996) och Ashton m.fl. (2000).

${ }^{67}$ För mer information om lärlingsutbildningen i tyskspråkiga länder se Dionisius m.fl. (2008), Goeggel och Zwick (2009), Lehman (2005), Schober-Brinkmann och Wadensjö (1991) och Zwick (2007).

${ }^{68}$ Se till exempel SFS 1943:963, SOU 1948:27 och SOU 1966:3.
} 
nadsstrukturer och oreglerade utbildningsmodeller. Problemen med yrkesutbildningen i Storbritannien och USA brukar förknippas med utbildningens begränsade omfattning, svaga reglering och långtgående decentralisering. Arbetsgivarnas och de fackliga organisationernas engagemang är begränsat och integrationen mellan skolutbildning och utbildning på arbetsplatsen är svag. Dessutom har yrkesutbildningen en tydlig orientering mot de socialt och studiemässigt svagaste grupperna, vilket gör att den får låg status.

Trots att det finns en samsyn om att lärlingsutbildningsmodellen kan ha positiva effekter genom att minska ungdomsarbetslösheten, betonar flera forskare, till exempel James Ainsworth och Vincent Roscigno (2005), att frånvaron av effektiva institutionella ramverk gör att utbildningen ibland kan förstärka klass- och etnicitetsklyftor. Det hävdas då att fördelen med lärlingssystem inte i första hand är att utbildningen ger enskilda elever kontakter i arbetslivet utan att det organiserade utbytet mellan skola och arbetsliv möjliggör ett utbud av yngre arbetskraft med kvalifikationer, som är relevanta ur företagens perspektiv. Yossi Shavit och Walter Müller (2000) menar att detta underlättar en konkurrensstrategi inriktad på flexibel arbetsorganisation och produktutveckling, något som indirekt förhindrar ökade samhällsklyftor.

\subsection{Lärlingsutbildning i Sverige}

Lärlingsutbildningen har för närvarande liten omfattning i Sverige, men förekommer inom och utanför gymnasieskolan som avtalsreglerad färdigutbildning inom vissa branscher. I detta kapitel behandlar vi emellertid enbart lärlingsutbildning i anslutning till gymnasieskolan. Det finns en tydlig vilja att öka omfattningen av lärlingsutbildningen. Sedan hösten 2008 pågår en försöksverksamhet med lärlingsutbildning inom den svenska gymnasieskolan som följs kontinuerligt av en särskild Nationell lärlingskommitté.69 Under vintern 2010/2011 deltog omkring 10000

\footnotetext{
${ }^{69}$ Se SFS 2007:1349.
} 
elever i försöksverksamheten. Hösten 2011 introducerades reguljär lärlingsutbildning i gymnasieskolan.

Gymnasial lärlingsutbildning är ett förhållandevis nytt inslag inom svensk utbildning. Försöksverksamhet med gymnasial lärlingsutbildning har funnits tidigare men aldrig fått ett genomslag. Den utbildning som nu har introducerats ska göra det möjligt att förena studierna med en anställning, precis som i den klassiska lärlingsutbildningen. För att klargöra de arbetsrättsliga förutsättningarna tillsattes 2009 en utredning, vars förslag om en särskild anställningsform för lärlingar ligger till grund för den lärlingsutbildningsmodell som infördes i den nya gymnasieskolan hösten 2011. ${ }^{70}$ Det kommer emellertid inte att finnas något krav på en lärlingsanställning, vilket skiljer Sverige från Danmark och Norge. Skolorna har huvudansvaret för utbildningen. Det mesta talar för att lärlingsanställning inte kommer att bli särskilt vanligt förekommande.

Skolor som deltog i försöksverksamheten skulle upprätta lärlingsråd med företrädare från skola, arbetsgivare och fackliga organisationer. Ett särskilt statsbidrag om 25000 kronor betalades för varje lärling utöver den skolpeng som ges till alla elever. Bidraget gick till skolorna, som skulle använda medlen för att bland annat administrera samordningen med arbetsplatserna och finansiera utbildning av handledare på företagen. I uppföljningar av den gymnasiala lärlingsutbildningen har påtalats flera brister, bland annat har skolorna inte satsat på utbildning av handledare på arbetsplatserna. Regeringen beslutade därför att 15000 av det extra statsbidraget skulle kunna avsättas till företag som tog emot lärlingar. Annan kritik som framfördes i anslutning till försöksverksamheten var att lärlingsråden inte som planerat blev den instans som godkände utbildningsplatser för lärlingar, inte ägnade sig åt att ta fram konkreta utbildningsplaner och inte hade någon central roll för kvalitetsuppföljningen av utbildningen på arbetsplatserna.

Inom ramen för den reguljära lärlingsutbildning som nu har etablerats kommer det inte att finnas något krav på särskilda lärlingsråd. Däremot finns krav på att gymnasieskolorna ska sluta utbildningskontrakt med de

\footnotetext{
${ }^{70}$ Se SOU 2010:19.
} 
arbetsplatser som tar emot lärlingar och inrätta lokala programråd för samråd med arbetsmarknadens parter. ${ }^{71}$ De lokala programråden kommer att få en betydligt svagare ställning än lärlingsråden. De ska inte ha den centrala roll för uppföljning och kvalitetssäkring av utbildning som lärlingsråden hade och inte heller något specifikt ansvar för lärlingsutbildning utan hantera alla frågor som rör gymnasial yrkesutbildning. Det finns till exempel inga möjligheter för programråden eller skolorna heller för den delen att ställa krav på att det ska finnas utbildade handledare på arbetsplatserna. Det saknas närmare anvisningar vad gäller utformningen av och uppföljning av de utbildningsavsnitt som ska organiseras på arbetsplatserna.

I praktiken innebär detta att arbetslivets ansvar för den svenska lärlingsutbildningen blir mindre påtaglig, och att regleringen av utbytet mellan skola och arbetsliv blir betydligt mindre framträdande än i länder som Norge och Danmark. Den svaga regleringen kan i sin tur leda till problem, inte bara när det gäller kvalitetssäkringen av utbildningen, utan också när det gäller möjligheterna att öka antalet deltagare på de utbildningsområden där arbetslivets efterfrågan är mest påtaglig. Lärlingsutbildningens styrka är ett starkt samband mellan utbildningarnas inriktning och arbetslivets efterfrågan, men genom att ansvaret för utbildningen ligger mer på skolan blir sambandet mindre starkt.

De yrkesutbildningar, som etablerades med den nya gymnasieskolan hösten 2011, ska enligt intentionerna erbjuda mer färdigutbildning. Gymnasial lärlingsutbildning blir följaktligen ett valbart alternativ inom samtliga yrkesutbildningsprogram. Avsikten är att en högre standard på yrkesutbildningen ska höja ungdomarnas produktivitet och minska företagens upplärningskostnader och därmed underlätta för eleverna att få arbete efter utbildningen. Samtidigt ska en mer påtaglig arbetslivsanknytning öka studiemotivationen och minska utslagningen från utbildningarna. Det sistnämnda motivet är mycket starkt framträdande.

De yrkesspecifika ämnena kommer att få större utrymme än i dagens gymnasieskola. Alla yrkesutbildningar ska resultera i en fastställd yrkesexamen. De kommer däremot inte att leda fram till grundläggande behö-

\footnotetext{
${ }^{71}$ Se SFS 2010:2039 samt Prop. 2010/11:104.
} 
righet för högskolestudier, vilket var målet för samtliga program fram till gymnasiereformen 2011. Eleverna, också de som följer en lärlingsutbildning, ska dock kunna göra ett individuellt val som garanterar högskolebehörighet inom ramen för yrkesutbildningen.

\subsection{Frågetecken kring den nya lärlingsutbildningen i Sverige}

En fråga som ofta diskuteras är lärlingsutbildningens effekter på ungas arbetslöshet och sysselsättning. I lärlingsutbildningsländerna är ungdomsarbetslösheten oftast relativt låg. Det är dock delvis en statistisk artefakt då lärlingar (men inte de som yrkesutbildas i skolform) räknas som sysselsatta och tillhörande arbetskraften, vilket ökar andelen som räknas som sysselsatta och sänker andelen som räknas som arbetslösa av dem i arbetskraften. Det som är mest intressant är emellertid att undersöka vad som händer efter avslutad utbildning - lärlingsutbildning eller utbildning i skolform. Flera undersökningar pekar på goda resultat av lärlingsutbildningen. Många får arbete på den arbetsplats där de haft sin lärlingsperiod och för andra kan lärlingsperioden ge en användbar referens.

När lärlingsutbildning introduceras i större skala, är det viktigt att lyfta fram sådana skillnader mellan Sverige och länder med omfattande lärlingsutbildning, som kan påverka hur lärlingsutbildningen fungerar. En viktig skillnad är att många yrken i lärlingsländerna är reserverade för dem som har genomgått sådan utbildning. Sverige har endast få sådana yrken och det finns inte heller planer på att införa nya. En annan skillnad är att det sedan länge etablerade finansieringssystem för lärlingsutbildning i dessa länder, där flera parter bidrar till att täcka kostnaderna. Det är betydligt svårare att introducera ett nytt system än att fortsätta med ett existerande. En tredje skillnad är betoningen i Sverige på att det ska vara en utbildning med socialpolitiska mål (utbildning för dem som är skoltrötta), vilket kan göra utbildningen mindre attraktiv för arbetsgivarna men också för dem som inte är skoltrötta.

Man kan befara att regleringen av lärlingsutbildningen i Sverige utformas så att den blir mindre anpassad till arbetslivets krav och till de utmaningar som följer av generationsväxlingen på arbetsmarknaden. 
Arbetslivets ansvar för lärlingsutbildningen är i praktiken mycket begränsad. Skolorna har det avgörande ansvaret och samarbetet med arbetsplatserna regleras via särskilda utbildningskontrakt. Via lokala programråd ska det ges möjligheter till samråd med arbetslivets intressen. Motsvarande möjligheter ges på central nivå via nationella programråd, men de sistnämnda råden har egentligen bara en rådgivande funktion till statens skolverk. I praktiken blir den svenska lärlingsutbildningen mer skolstyrd än t.ex. den norska och danska, arbetslivets ansvar blir mindre framträdande. Detta leder i sin tur till att utbildningens innehåll och volymer i mindre utsträckning svarar mot de krav som ställs i arbetslivet - parallellt med att utbildningsformen i sig tenderar att få en svagare status jämfört med skolförlagd och mer allmänteoretisk utbildning.

Vår övergripande slutsats är följaktligen att den svenska lärlingsutbildningen riskerar att bli allt för svagt kopplad till arbetslivets behov. De lokala programråden, som ska fungera som en mötesplats mellan skolans och arbetslivets företrädare, får en allt för svag och odefinierad roll. Lärlingsutbildningen riskerar att bli en utbildningsform utan egentlig förankring varken i skolan eller i arbetslivet. Huvudproblemen rör regleringen och kvalitetssäkringen av utbildningen. Nedan presenteras några rekommendationer. ${ }^{72}$

- På skolor med lärlingsutbildningar som spänner över flera branschområden kan det vara ett problem att få ett tillräckligt starkt yrkesfokus inom de lokala programråden. Det gör att de deltagande parterna - framför allt från arbetslivet - förmodligen kommer att känna sig mindre berörda av de diskussioner och frågor som behandlas på rådens möten. På skolor med ett större antal lärlingar är det en bättre idé att inrätta särskilda yrkesråd som delegeras uppgifter att ta fram uppdaterade yrkesplaner och med utgångspunkt från dessa organisera uppföljning och kvalitetssäkring av den arbetsplatsförlagda utbildningen.

${ }^{72}$ Se SOU 2010:75, bilaga 4, för en närmare belysning av dessa aspekter. 
- Metoderna för kvalitetssäkringen av den arbetsplatsförlagda delen av lärlingsutbildningen, som omfattar minst 50 procent av utbildningstiden, är helt avgörande för en likvärdig och rättsäker hantering av utbildningen. Kvalitetssäkringen och uppföljningen ska omfatta välstrukturerade och återkommande trepartssamtal med företrädare för skolan, handledare på arbetsplatsen och elever. Dessa samtal bör baseras på uppdaterade och detaljerade utbildningsplaner och yrkesbeskrivningar. Det måste vara en strategisk uppgift för programråden att se till att sådana utbildningsplaner finns tillgängliga på alla områden där det finns lärlingar.

- För att garantera kvalitet och bredd i utbildningen finns det anledning att eftersträva rotation för eleverna i den arbetsplatsförlagda delen av utbildningen. Det kan givetvis finnas naturliga hinder för ett sådant system, men där antalet involverade företag är tillräckligt stort bör programråden och skolorna försöka organisera ett system för växelutbildning. Det borde finnas anvisningar om detta i gymnasieskolans styrdokument. Sådana anvisningar saknas idag.

- Det saknas helt ett system för att utse arbetslivsföreträdare i programråden. Det här föranleder inte bara bristande likvärdighet och godtycke ur ett representations- och inflytandeperspektiv. Det skapar dessutom oklarheter gällande rådens och ledamöternas fullmakter. Vilka intressen representerar de och vilket mandat har de att ta beslut som berör konkreta utbildningsfrågor? I praktiken riskerar oklarheterna gällande rådsledamöternas mandat att leda till att råden blir mer av en diskussionsklubb utan påtagligt inflytande.

- Mycket talar för att lärlingsutbildningen på många skolor ställs inför ett logistikproblem som hänger samman med yrkeslärarnas dubbla roller: att dels bedriva karaktärsämnesundervisning för yrkeselever på de skolförlagda programmen och dels hinna med att följa upp lärlingarna på arbetsplatserna. Uppföljningsarbetet med lärlingar och handledare blir ofta lidande. På större skolor med fler lärlingar bör man eftersträva att anställa särskilda utbildningssamordnare som uteslutande ägnar sig åt lärlingsutbildningen. På de skolor där man har utbildningssamordnare fungerar utbytet mellan skola och arbetsplatser oftast bättre. 
- Idag placeras ofta eleverna ut tre dagar i veckan på en arbetsplats redan från första läsårets första termin på ett yrkesprogram. En introduktionsperiod med mer omfattande skolförlagda studier skulle underlätta introduktionen och lärandet på arbetsplatserna. Det bör övervägas om inte den arbetsplatsförlagda delen av utbildningen skulle begränsas under det första läsåret, i likhet med förhållandena i Norge. Detta skulle säkert kunna bidra till att öka trivseln med utbildningen samtidigt som matchningen mellan elever och arbetsplatser skulle underlättas.

- Lärlingsutbildningens kvalitet och elevernas villkor står och hänger med handledarnas insatser. Det finns anledning att betona att handledning bör betraktas som en professionell insats som förutsätter gedigen kompetens hos handledarna. Handledarutbildningen måste uppvärderas. Flertalet handledare på arbetsplatserna är inte utbildade. De lokala programråden bör ges i uppdrag att garantera att alla arbetsplatser som tar emot lärlingar har kompetenta handledare. De företag vars handledare deltar i utbildningen borde rimligen få ekonomisk kompensation för detta. En bättre organiserad handledarutbildning borde kunna utgöra en merit vid löneförhandlingar och dessutom beaktas vid ansökningar till yrkeslärarutbildning.

- Lärlingsutbildningen innebär att karaktärsämnesundervisningen förflyttas till en arbetsplats. Det är vanligt att eleverna tillbringar tre dagar i veckan eller 60 procent av utbildningstiden på en arbetsplats. Samtidigt får skolan en skolpeng som tidigare (inklusive ett särskilt statsbidrag inom ramen för försöksverksamheten). Man sparar in på yrkeslärare samtidigt som skolans intäkter förblir oförändrade - eller till och med högre än tidigare. Det här är ett farligt mönster. Lärlingsutbildning är en kvalificerad och krävande utbildningsform som inte bara ställer krav på elever och medverkande arbetsplatser utan också i allra högsta grad på skolornas insatser. Systemet med uppföljning och kvalitetssäkring kopplade till enskilda arbetsplatser, samt handledarutbildning, ställer stora krav på arbetstid, resurser och kompetens. Lärlingsutbildning ska inte uppfattas som en "billigare" utbildningsform. Ett sätt att motverka de incitament som kan finnas att utnyttja utbildningsformen på det sättet är att utvidga de lokala programrådens ansvar och befogenheter till att också fatta beslut om resursfrågor och medelstilldelning. 


\subsection{Slutord}

Den svenska lärlingsutbildningen har hittills i hög grad präglats av utbildningspolitiska och socialpolitiska motiv. Så måste det naturligtvis vara till en del. Problemet är att arbetslivets intressenter enbart i begränsad utsträckning har varit delaktiga i processen att forma en lärlingsutbildning inom gymnasieskolans ram. Det gör att lärlingsutbildningen kan framstå som konstlad. Den har inte uppfattats som en naturlig produkt av de behov av arbetskraftsoch kompetensförsörjning som svensk arbetsmarknad står inför. Men lärlingsutbildningens former och innehåll kommer säkerligen att förändras efter hand som arbetsmarknadens parter och enskilda arbetsgivare ser de möjligheter som en förändrad yrkesutbildning erbjuder.

Hur kan då, avslutningsvis, en utökad och bättre fungerande lärlingsutbildning bidra till svar på de tre utmaningar vi nämnde i inledningen? Den kan troligen för vissa ungdomar bidra till en snabbare etablering på arbetsmarknaden och därmed bidra till att mildra de problem som den demografiska utvecklingen innebär. Den kan kanske också för vissa ungdomar, som har svårt att tillgodogöra sig en mer teoretiskt inriktad undervisning, vara en möjlighet till en yrkesutbildning. En stark betoning av en sådan inriktning av lärlingsutbildningen kan dock innebära problem för dess status. Vad gäller den tredje utmaningen - att utbilda på ett sätt som stärker den framtida flexibiliteten - kan en starkt yrkesinriktad utbildning för en del leda till framtida arbetsmarknadsproblem om inte det finns goda möjligheter till en kompletterande utbildning längre fram. 



\section{Lærlinge-uddannelsers koblinger til arbejdsmarkedet}

Christian Helms-Jørgensen, Roskilde Universitetscenter

Blandt politiske beslutningstagere i de nordiske lande er der generelt stor interesse for uddannelser baseret på lærlinge-princippet hvor en betydelig del af uddannelsestiden er forlagt til en arbejdsplads. Det kom til udtryk i Sveriges etablering af en ny selvstændig moderne lærlingeuddannelse og i oprustningen af lærlingeuddannelserne i Norge med reform 94 og kompetenceløftet. I Danmark har lærlingeuddannelser som beskrevet historisk en stærk rolle i det samlede uddannelsessystem. Interessen for lærlingeuddannelser skyldes ikke mindst at de kan sikre bogligt svage unge en god adgang til arbejdsmarkedet. Det skyldes at de er baseret på vekseluddannelsesprincippet og at arbejdsmarkedets parter tager ansvar for at sikre erhvervsuddannelsernes relevans for arbejdsmarkedet. Der er dog peget på nogle svagheder i lærlingeuddannelserne med hensyn til koblingen til arbejdsmarkedet. Det drejer sig om systemets evne til hurtigt at uddannelsesdække nye jobområder og tværfaglige uddannelsesbehov og til at udbyde fleksible erhvervsuddannelser med kortere varighed.

Der er også peget på nogle svagheder i vekselprincippet, hvor eleverne skifter mellem skole og arbejdsplads. Det drejer sig om manglen på praktikpladser i forhold til elevernes uddannelsesvalg, om et misforhold mellem udbuddet af praktikpladser og arbejdsmarkedets fremtidige behov og om et misforhold mellem uddanner- og aftagervirksomheder, om manglen på adgang til videregående uddannelse for personer, der vælger en erhvervsuddannelse, samt problemer med et højt frafald i erhvervsuddan- 
nelserne. Disse problemer i koblingen mellem erhvervsuddannelserne og arbejdsmarkedet vil blive vurderet i det følgende.

\subsection{Koblinger gennem det faglige selvstyre}

Staten har generelt anerkendt værdien af at arbejdsmarkedets parter tager et medansvar for udviklingen af erhvervsuddannelserne, selvom der gennem tiden har været en vis konkurrence mellem den statslige styring og det faglige selvstyre. I Danmark er der fra politisk hold er der stillet spørgsmålstegn ved om det faglige selvstyre er effektivt i forhold til at identificere og uddannelsesdække nye jobområder (Globaliseringsrådet 2006). Der peges på at brancheglidninger og ændringer i erhvervsstrukturen skaber behov for nye kompetencer i fremstillingen af mere kundetilpassede produkter, anvendelse af IKT og udviklingen af helt nye arbejdsfunktioner og brancher som eksempelvis oplevelsesøkonomi, velvære, sundhed og sport. De historisk velafgrænsede faglige udvalg, som bygger på de hidtidige brancher, kritiseres for ikke hurtigt nok at opfange og uddannelsesdække nye behov, der går på tværs af eksisterende faglige udvalg. Der er derfor iværksat en række nye tiltag til forbedring af erhvervsuddannelsernes koblinger til arbejdsmarkedet.

Fornyelse af de eksisterende uddannelser, så de matcher arbejdsmarkedets behov. I Danmark skal sikres det ved at de faglige udvalg hvert år til ministeriet skal indsende en udviklingsredegørelse, der analyserer den erhvervsmæssige udvikling og udviklingsmulighederne indenfor området og overvejer om der er behov for nyetablering, omlægning eller nedlæggelse af uddannelser. For eksempel viste undersøgelsen af beskæftigelsesfrekvenser for de færdiguddannede i 2009, at der var problemer inden for syv uddannelser (Undervisningsministeriet 2010). De faglige udvalg blev af ministeriet pålagt at tage initiativer til forbedring af beskæftigelsesmulighederne for de færdiguddannede. Efter ønske fra Rådet for de Grundlæggende Erhvervsrettede Uddannelser blev endvidere seks faglige udvalg kontaktet, fordi beskæftigelsesfrekvensen for færdiguddannede med anden etnisk baggrund end dansk lå relativt lavt.

Dækning af nye uddannelsesområder: den danske regering har taget initiativer, der kan sikre en uddannelsesdækning af nye spirende vækstom- 
råder, som ikke er organiserede inden for de eksisterende strukturer i det faglige selvstyre. Undervisningsministeriet har oprettet en særlig pulje, der siden 2008 har finansieret over 30 analyser og prognoser, som skal bidrage til udvikling af uddannelserne. Disse løbende analyser giver input til de faglige udvalgs arbejde med fornyelse af uddannelserne. Det sker ved for eksempel at undersøge, hvilke kompetencer de faglærte faktisk anvender, og hvilke jobs de bestrider, udviklingen af nye vækstområder og internationale erfaringer (www.fagligeudvalg.dk). Undervisningsministeriet fik også mulighed for selv at oprette udviklingsudvalg med henblik på etablering af nye erhvervsuddannelser. Med henblik på et mere fleksibelt lokalt udbud har skolerne fået muligheder for lokalt at tilrettelægge individuelle erhvervsuddannelser.

Korte erhvervsuddannelse: lærlingeuddannelser har ofte en varighed på 3-4 år. Nogle unge kan ikke overskue at gennemføre en uddannelse der er så lang. Derfor indførtes i Danmark 2005 på initiativ fra Undervisningsministeriet 21 nye korte erhvervsuddannelser trods skepsis fra de faglige udvalg. Hensigten var at give unge, der ikke kan overskue et 3-4 årigt uddannelsesforløb, et tilbud om en kortere uddannelse Der er peget på at parterne kan have fælles interesse i at øge kravene til uddannelsernes indhold og kompetencer og forfølge „insider“-interesser på bekostning af de ufaglært og restgruppen (Groes 2005). Det viste sig efterfølgende, at undervisningsministeriet efter tre år måtte lukke halvdelen af de nye korte erhvervsuddannelser, fordi der hverken var interesse blandt de unge for at søge ind på uddannelserne eller efterspørgsel på arbejdsmarkedet for uddannelserne. Det viser betydningen af at arbejdsmarkedets parter har ejerskab til nye uddannelser.

Fag, brancher eller klynger: Koblingen mellem uddannelse og beskæftigelse sker i Danmark med udgangspunkt i erhvervsfaget (yrket) formidlet via de faglige udvalg. Det bidrager til en højere grad af professionalisering af arbejdsområder, som i andre lande udføres af ufaglærte og tillærte. Der er dog stillet spørgsmålstegn ved om erhvervsfag fortsat er relevante institutioner til kobling af uddannelse og arbejde (Baethe 1998). I stedet peges der på at kompetencebehov udvikles i tilknytning til erhvervsklynger (clusters), som udgør kernen i mange nye vækstcentre (energi, miljø, fødevarer). Det er derfor foreslået at analyser af kvalifikationsbehov tager udgangspunkt i erhvervs- og kompetenceklynger for at opfange nye bran- 
che- og teknologidynamikker i et uddannelses- og kvalifikationsperspektiv. Der er meget få erfaringer med disse metoder, se for eksempel Bjerre \& Kjeldsen (2010).

\subsection{Koblinger via vekseluddannelser}

Vekseluddannelse med virksomhedspraktik er som nævnt meget effektive i forhold til at skabe en høj beskæftigelsesfrekvens og sikre kompetencer der er relevante på arbejdsmarkedet. Men praktikdelen af erhvervsuddannelserne har også en række svagheder.

1. Dimensionering og udbud. I modsætning til de øvrige uddannelser kan staten ikke dimensionere kapaciteten i erhvervsuddannelserne ud fra prognoser om det fremtidige behov (det kan kun ske via skolepraktikken). Dimensioneringen sker i stedet for i et komplekst samspil mellem udbuddet af pladser på praktikpladsmarkedet og unges valg af erhvervsuddannelser. En række ændringer i markedsforhold, teknologi og organisation forandrer virksomhedernes muligheder for at tilbyde praktikpladser. Der sker et skifte fra traditionelle brancher til nye brancher og fra industri til service, der har svagere traditioner for at udbyde praktikpladser. Teknologiudviklingen medfører at hver enkelt arbejdsplads og praktikplads koster stadig mere at etablere. Samtidig bliver medarbejderens kontakt med produktionen mere indirekte og sker via skærme og symboler. Det betyder at der bliver mindre mulighed for at oplære uerfarne unge direkte i produktionen (Jørgensen m.fl. 2006). Den øgede specialisering i virksomhederne medfører at den enkelte virksomhed i mindre grad kan tilbyde den faglige bredde, som en erhvervsuddannelse kræver. Desuden indebærer globaliseringen at stadig flere virksomheder bliver underlagt transnational ledelse, som ikke oplever nogen forpligtelse til at uddanne lærlinge i den duale model. Endelig medfører ændringer på kapitalmarkederne at virksomhederne i højere grad forfølger en kortsigtet „bundlinie-tænkning“ som modvirker at de forpligter sig til en praktikaftale på tre år (Kupfer 2010) 
2. Fremtidige behov. Der er ingen direkte sammenhæng mellem det fremtidige behov for faglærte og det aktuelle udbud af praktikpladser. Kun en mindre del af praktikvirksomhederne antager lærlinge med henblik på senere rekruttering. Generelt sker udbuddet af praktikpladser ud fra en forventning om rentabilitet i enkeltvirksomhederne: Lærlinge ansættes i princippet, når det kan betale sig for den enkelte virksomhed, og ikke når der er behov for faglærte på arbejdsmarkedet. Denne begrænsning på antallet af elever i erhvervsuddannelserne findes ikke i de gymnasiale ungdomsuddannelser, der er rent skolebaserede og som finansieres af staten. I Danmark er manglen på praktikpladser en af årsagerne til at en stigende andel af en ungdomsårgang har søgt til de gymnasiale uddannelser. Det har dog en negativ effekt i forhold til arbejdsmarkedet, idet $8 \%$ af en ungdomsårgang gennemfører en gymnasial uddannelse uden at få nogen uddannelse med erhvervskompetence. Denne gruppe har en ringere beskæftigelsesgrad og indkomst end unge der gennemfører en erhvervsuddannelse (AERådet 2011)

3. Konjunktur-forstærkende effekt. Det er i nogle brancher (ex byggeriet) et problem, at de konjunkturelle svingninger i beskæftigelsen fører til endnu stærkere svingninger i antallet af praktikpladser. Det bidrager til at forøge problemerne med flaskehalse med mangel på faglærte under en konjunkturopgang

4. Uddanner-og aftagervirksomheder. Det er kun en omkring en femtedel af alle danske virksomheder, som deltager i uddannelsen af lærlinge (Anker 1998) eller kun 7 \% målt som andel af produktionsenhederne (LO 2009). Det er også kun en lille del af de virksomheder, som beskæftiger faglærte, som er godkendte til at oplære elever. Der er betydelig forskel på de virksomheder, som uddanner lærlinge, og de virksomheder som be-skæftiger dem efter at de har gennemført uddannelsen. Det er især virksomheder med mellem 10 og 50 ansatte som uddanner lærlinge. Der er en tendens til at især de løntunge og lavteknologiske virksomheder uddanner flere lærlinge, end de beskæftiger for eksempel mekanikere, frisører og bagere (Anker 1998). Samtidigt er det en afgørende kvalitet ved de danske erhvervsuddannelser, at de bygger på nationalt standardiserede kompetenceprofiler, som svarer til de kompetencer som faktisk anvendes på det delarbejdsmarked, hvor de faglærte beskæftiges. Det er 
forudsætningen for de faglærtes høje mobilitet på arbejdsmarkedet, at uddannelserne har en almen værdi indenfor hele området. Men den omtalte forskel mellem uddanner- og aftagervirksomheder medfører, at der vil være forskel på de kompetencer, der læres under uddannelsen, og de kompetencer, som anvendes i den efterfølgende beskæftigelse (Lassen 1986)

5. Kvaliteten i uddannelserne står overfor virksomhedernes interesse i at udnytte lærlingen som arbejdskraft. Den tilbagevendende mangel på praktikpladser indebærer at vist "trade-off" mellem kvaliteten af oplæringen og antallet af praktikpladser (kvantiteten). Der er i Danmark ikke krav om nogen uddannelse eller kvalificering af oplærere/instruktører i forbindelse med godkendelse af virksomheder til at uddanne elever

6. Gennemsigtighed. Mens udbuddet af uddannelsespladser på andre uddannelser sker åbent og gennemsigtigt, så udbydes en stor del af praktikpladserne ikke åbent, men fordeles ofte via sociale og personlige netværk. Det rammer grupper som ikke har adgang til sådanne netværk, og det bidrager til at fastholde etniske og kønsmæssige opdelinger på arbejdsmarkedet. I Danmark er der skabt større gennemsigtighed gennem en service på nettet (www.praktikplads.dk), der giver oversigt over de virksomheder, der er godkendte til at have lærlinge, og samtidig giver information om disse virksomheder har lærlinge aktuelt

7. Adgang til videregående uddannelser: Generelt opnår unge, der gennemfører en erhvervsuddannelse, ikke adgang til videregående uddannelser (tertiært niveau). Det bidrager til at give erhvervsuddannelsernes lavere status, at de opfattes som "blindgyde“ i forhold til videreuddannelse. Den lave "gennemtrængelighed“ mellem erhvervsuddannelserne og de videregående uddannelser reducerer fleksibiliteten og øger skævheden i rekrutteringen til de videregående uddannelser. Det begrænser desuden mobiliteten på arbejdsmarkedet, fordi det er vanskeligt for voksne faglærte at opnå studiekompetence (Jørgensen 2010; 2011)

Vekseluddannelserne har mange fordele, blandt andet at de sikrer en effektiv overgang fra skole til arbejdsmarked (transition) og en lav ungdomsarbejdsløshed. Men der er behov for at finde løsninger på de nævnte svagheder, hvis 
dette gode princip skal overleve i fremtiden. Blandt forslag til løsninger, som ikke er gennemført, er at indføre kvoter for praktikpladser (Jørgensen m.fl. 2006) og at flytte ansvaret for praktikpladser fra enkelt virksomheder til skoler eller erhvervsorganisationer (Øørgensen \& Juul 2010). Nogle af de forslag, som er gennemført, er kombinationspraktik, skolepraktik og statstilskud til oprettelse af nye praktikpladser og en erhvervsuddannelse der giver studiekompetence (eux), som alle uddybes i det følgende.

Kombinationspraktik. I takt med specialisering af produktionen begrænses virksomhedernes muligheder for at tilbyde lærlingene hele den faglige bredde i uddannelsen som kræves i bekendtgørelsen. Der er mulighed for at oprette kombinationsaftaler, hvor flere virksomheder i fællesskab deles om oplæringen. Når kombinationsaftaler har begrænset udbredelse, skyldes det at kendskabet til ordningen er begrænset, at virksomhederne oplever ordningen som en administrativ byrde, og at muligheden for senere at rekruttere lærlingen som medarbejder forringes. Desuden indeholder ordningen ikke mekanismer der sikrer den økonomiske balance for virksomhederne. I kombinationspraktik risikerer virksomhederne at investere i oplæringen i starten af lærlingens læretid uden at få nytte af denne investering ved at have lærlingen i slutningen af læretiden. Her repræsenterer de norske oplæringsringe/kontorer og de schweiziske oplæringsforbund interessante modeller for, hvordan dette problem kan løses (Jørgensen \& Juul 2010).

Skolepraktik. En svaghed i lærlingeuddannelser er afhængigheden af praktikpladser udbudt af virksomhederne. Siden 1993 har elever i Danmark som ikke kunne finde en praktikplads haft mulighed for at gennemføre deres erhvervsuddannelse i en skolebaseret uddannelse (skolepraktik). Der er dog en række begrænsninger i adgangen til skolepraktik. Kun en tredjedel af erhvervsuddannelserne udbydes i skolepraktik uden adgangsbegrænsning, og desuden har skolepraktik en lav status, og derfor betragter mange elever ikke skolepraktik som noget relevant alternativ. Eleverne i skolepraktik uddannes efter samme regler som elever i ordinær praktik og afslutter med samme eksamen (svendeprøve). Skolepraktik betragtes ikke som et permanent tilbud i lighed med skolebaserede erhvervsuddannelser i Holland eller Schweiz, men kun som en kompensation for manglende ordinære praktikpladser. Derfor svinger antallet af elever meget afhængigt af de økonomiske konjunkturer. I 2004 udgjorde 
skolepraktikken $13 \%$ af alle elever i erhvervsuddannelserne, men det faldt til 3-4 \% i 2007. Flertallet af de elever som starter i skolepraktik, afslutter deres uddannelse i en ordinær virksomhedspraktik, blandt andet fordi de er forpligtet til fortsat at søge en ordinær praktikplads. De elever som gennemfører hele uddannelsen i skolepraktik har en lavere beskæftigelsesfrekvens (66\%) end elever uddannet i ordinær praktik (85\%), mens elever som starter i skolepraktik og afslutter i ordinær virksomhedspraktik kun ligger lidt under gennemsnittet (80 \%). Når elever i skolepraktik klarer sig dårligere på arbejdsmarkedet skyldes det en kombination af svagere forudsætninger hos deltagerne, en negativ holdning hos arbejdsgiverne og at de nyuddannede - ikke som de øvrige elever - kan fortsætte i den virksomhed, hvor de er uddannet (Jørgensen \& Juul 2010).

Eux: Da lærlingeuddannelser som udgangspunkt ikke giver adgang til videregående uddannelser, er der i flere lande tilbud som kombinerer studiekompetence med arbejdsmarkedskompetence. I Danmark er der medio 2010 vedtaget en ny lov om et sådan uddannelsestilbud (eux), som i 2011 udvidet til nye områder og har en god søgning (Jørgensen \& Lindvig 2011).

Statstilskud: i både Sverige, Danmark og Norge giver staten tilskud til enten skoler eller virksomheder til etablering af praktikpladser. I Danmark forsøger Undervisningsministeriet gennem tilskudsordninger i 2010 og 2011 på $70.000 \mathrm{kr}$ til virksomheder at stimulere til oprettelse af flere praktikpladser i perioder med stor mangel på praktikpladser.

\subsection{Koblinger gennem kvalifikationsanalyser}

Opgaven med at sikre arbejdsmarkedets behov for kompetencer er skiftet fra makroniveau til mikroniveau (og mesoniveau: erhvervsfag/branche). Troen på en samlet statslig planlægning af det fremtidige kvalifikationsog uddannelsesbehov er fra 1980erne afløst af øget tro på markedsregulering og analyser af kvalifikationsbehovet på branche-, fag- og virksomhedsniveau. Til forskel fra planlægningen på samfundsniveau, som typisk byggede på fremskrivninger og modelberegninger af aggregerede statistiske data, så bygger de fag- og virksomhedsrettede analyser i højere grad på kvalitative undersøgelser på branche- og virksomhedsniveau blandt andet i form af case-analyser i såkaldte spydspidsvirksomheder. 
Uddannelsesplanlægning har primært bygget på kvalifikationsanalyser i form af „gab-analyser“, der analyserer „gabet“ mellem udbud af og efterspørgsel efter kompetencer. Metoden i denne tilgang indeholder en række basale trin: 1 . at identificere de nuværende eller fremtidige kompetencebehov, 2. at kortlægge arbejdsstyrkens nuværende kompetencer eller at forudsige det fremtidige udbud af kompetencer og 3. at planlægge og tilrettelægge uddannelser, der kan lukke „kompetencegabet“. Denne tilgang spiller stadig en betydelig rolle både på virksomhedsniveau, på brancheniveau og på nationalt niveau (ex Finansministeriet 2010).

Tilgangen har dog en række svagheder som betyder at den ikke kan stå alene som metode til at sikre samspillet mellem uddannelse og arbejdsmarked (Jørgensen 2006). Det skyldes for det første, at gabanalysen fokuserer på de kvalifikationer, som arbejdsstyrken mangler, frem for at se på de ressourcer og potentialer, som arbejdsstyrken besidder, og på hvordan disse ressourcer kan udnyttes bedre til udvikling af produktionen. Gabanalysen sigter på at tilpasse de ansatte til arbejdsmarkedets krav, frem for at udvikle arbejdsmarkedet og arbejdslivet, så de giver plads til udvikling og udfoldelse af medarbejdernes potentialer og skabende evner. For det andet skyldes det metodens funktionalistiske tilgang, som overser den rolle uddannelse og kompetencer har for arbejdsmarkedets organisationer og for de arbejdende menneskers arbejdsidentitet, status, og sociale liv. Metoden kan for eksempel ikke bidrage meget til løsning af problemerne med at fă mænd fra etniske minoriteter gennemfører en uddannelse og derved har svært ved at begå sig på arbejdsmarkedet. For det tredje er det svært at sikre rettidighed (,timing") mellem udbud og efterspørgsel af kompetencer i en metode, der baseres på et allerede erkendt behov. Fra et behov erkendes og formuleres og til nye uddannelser udbydes og gennemføres, går der ofte flere år. Endelig overser metoden, at uddannelse ikke kun har til opgave bagudrettet at efterkomme erkendte behov arbejdsmarkedet, men at uddannelse også kan tilføre arbejdsmarkedet nye kompetencer, som fremadrettet udvikler og omskaber eksisterende produktionsformer. Det er en pointe i den internationale diskussion af grundlaget for udvikling af en „high skills“ økonomi, at de kræver et overskud af kvalifikationer, især i en situation, hvor fremtiden er foranderlig og uforudsigelig (Streeck 1992). 
Den industrisociologiske tradition, som kvalifikationsanalyserne bygger på, har generelt peget på at der bliver et øget behov for almene, personlige og sociale kvalifikationer - eller flere „bløde“ kompetencer i forhold til „hårde“. Det betød at kvalifikationsanalysernes énsidige fokusering på de krav, som blev stillet af teknologien og de ydre arbejdsvilkår, er blevet problematisk. Det skyldes, at de personer, som skulle tilføres kvalifikationer, og den læreproces, hvorved de skulle kvalificeres, tidligere har ligget uden for analysernes interessefelt. Men når analyserne peger på behovet for sociale og personlige kvalifikationer, er det nødvendigt at inddrage deltagernes forskellige forudsætninger, interesser og motivation. Hertil kommer den øgede markedsgørelse af uddannelserne som indebærer at dimensioneringen af uddannelserne i stigende grad bliver styret af de unges valg af uddannelse. Det betyder et $\emptyset$ get behov for at forstå de subjektive og kulturelle forhold, der påvirker disse valg. Det gælder for eksempel forståelsen af hvorfor relativt færre drenge end piger gennemfører en uddannelse ud over folkeskolen. Det har ført til et skifte fra funktionalistiske kvalifikationsanalyser, hvor uddannelsesbehovene blev fastlagt ud fra den fremtidige teknologi og arbejdsdeling, til en interesse for unges valg og veje i erhvervsuddannelserne og for læring i arbejdslivet med udgangspunkt i de ansattes baggrund og interaktion.

Desuden er der sket et skifte fra de deterministiske kvalifikationsanalyser til en øget forståelse af at virksomheder og brancher har et betydeligt spillerum til at udforme arbejdsdeling, jobprofiler og personaleanvendelse på forskellige måder. Det indebærer at ændringer i teknologi og markedsvilkår ikke i sig selv stiller bestemte kvalifikationskrav, men at ændringerne giver virksomhederne muligheder for at opdele eller integrere arbejdsfunktionerne på forskellige måder. Det betyder, at kvalifikationsanalyserne har skiftet rolle fra kun at være redskab til at bestemme og beskrive de fremtidige kvalifikationsbehov til også at være aktivt redskab for at fremme organisationsudvikling, fornyelse i arbejdslivet og formning af fremtidens arbejdsmarked. For eksempel kan udvikling af nye uddannelser indenfor sundhedsfremme i arbejdslivet bidrage til at reducere nedslidning og sygefravær og dermed løse de fremtidige problemer med mangel på arbejdskraft. Der er derfor behov for at kombinere gabanalyserne med uddannelsespolitiske initiativer som kan bidrage til at realisere nogle politisk definerede mål i samfundet. Det kan ske ved at uddannelsesinstitutionerne 
tildeles gode muligheder for selv at udvikle og udbyde nye uddannelser, der udfordrer givne strukturer og oplevede behov på arbejdsmarkedet. Uddannelsesinstitutionerne skal blandt andet have midler til at starte nye uddannelser og gives rimelig tid til at vise, at de kan tiltrække elever/studerende og give beskæftigelse til de uddannede.

\subsection{Koblinger gennem prognoser}

Prognoser af det fremtidige behov for arbejdskraft og kvalifikationer har spillet en vigtig rolle i styringen af uddannelserne i forhold til arbejdsmarkedets behov. Det har dog vist sig at være vanskeligt at udarbejde troværdige prognoser på blot lidt længere sigt. For eksempel blev prognoserne om en stor fremtidig mangel på arbejdskraft med høje ITkompetencer med kort varsel vendt til høj arbejdsløshed, da IT-boblen brast i 2001. Tilsvarende blev en stor mangel på faglærte indenfor byggeriet i 2007 afløst af en stor mangel på beskæftigelse for denne gruppe efter finanskrisen i 2008. Det havde næsten ingen forudset. Da den globale $ø$ konomi i stigende grad er styret af spekulationsprægede finanstransaktioner, har den vist sig at være meget ustabil og uforudsigelig. Der er derfor stor usikkerhed om den fremtidige udvikling i den globale økonomi og i virksomhedernes organisationsformer og teknologier, og derfor er det vanskeligt at forudsige de fremtidige kompetencebehov.

Danmarks Statistik følger løbende ændringer på arbejdsmarkedet ved en arbejdskraftundersøgelse, der udgives hvert kvartal på baggrund af telefoninterviews med 37.000 personer. Desuden udgiver OECD og EU løbende rapporter om det danske arbejdsmarked, som dog typisk ikke er specifikke i forhold til enkelte brancher og uddannelser. Hovedorganisationerne på arbejdsmarkedet udgiver jævnligt undersøgelser og prognoser af beskæftigelsesforhold. For eksempel peger Dansk Arbejdsgiverforenings årlige arbejdsmarkedsrapport i 2009 på at den demografiske udvikling og de unges uddannelsesvalg vil reducere udbuddet af faglærte på arbejdsmarkedet med 100.000 personer inden for de næste 10 år. Det største relative fald ventes at ske på social- og sundhedsområdet, hvor der samtidigt forventes et stærkt stigende behov for arbejdskraft på grund af befolkningens aldring. Rapporten peger på at faldet i udbuddet af faglærte modsvares af en stig- 
ning i personer med en videregående uddannelse, som i nogle tilfælde kan erstatte de manglende faglærte. Det gælder for eksempel finansområdet hvor et fald på omkring $25 \%$ i udbuddet af faglærte kan substitueres af personer med en kort videregående uddannelse (finans- og akademiøkonomer) som ventes at stige stærkt i samme periode. Tilsvarende peger $\mathrm{AE}$ Rådet (2008) at efterspørgslen efter faglærte forventes at stige med omkring 30.000 frem til år 2015. Da udbuddet af faglærte frem til år 2015 samtidigt forventes at falde med over 100.000 personer, så vil der om fem år være en omfattende mangel på faglært arbejdskraft.

Det danske Finansministerium (2009) har udarbejdet scenarier for det fremtidige behov for udvalgte faggrupper i den offentlige sektor. De variable forhold som indgår i de tre scenarier er på udbudssiden ændringer i studieoptaget, frafaldet under uddannelsen og kortere gennemførelsestider, og på efterspørgelssiden ændring i sygefravær, deltidsfrekvens og tilbagetrækningsalder. Hertil kommer mulige ændringer i efterspørgslen på grund af ny teknologi og organisationsformer, opgaveglidning, ændring af faggrænser og arbejdskraftsubstitution. Selvom den offentlige sektor er mindre konjunkturfølsom end private erhvervs, viser disse scenarier at der er en betydelig usikkerhed på sådanne tekniske fremskrivninger. Scenariet viser dog en klar tendens til et øget behov for uddannet arbejdskraft, som bygger på en aldersbetingede afgang, som med den givne pensionsalder, ligger fast. Samtidig er det demografisk betingede behov for øget ældreservice også en klar tendens i kraft af befolkningens aldring.

\subsection{Frafald i erhvervsuddannelserne}

Frafaldet i ungdomsuddannelserne har udløst politisk bekymring i alle de nordiske lande (Markussen 2010). Frafald præger også lærlingeuddannelserne. Det danske uddannelsessystem ser ud til at fungere dårligere $\mathrm{i}$ sammenligning med andre lande er, at en lavere andel af unge gennemf $\varnothing$ rer en ungdomsuddannelse. Andelen har gennem mere end 10 år ligget på omkring $80 \%$, som den opgøres i Danmark, hvilket betyder at $20 \%$ af de unge ingen uddannelse afslutter efter grundskolen (Jørgensen 2011). Det opfattes som et stort problem, da prognoserne entydigt peger på at behovet på arbejdsmarkedet for ikke-faglærte vil falde stærkt. Da over $95 \%$ af 
en ungdomsårgang starter på en ungdomsuddannelse efter grundskolen, ligger problemet i et stort frafald på især erhvervsuddannelserne. Her afbryder omkring $50 \%$ af de unge den uddannelse, som de starter på. Undervisningsministeriet har siden 2007 krævet at alle erhvervsskoler udarbejder handlingsplaner for øget gennemførelse, som skolerne skal offentliggøre. Ministeriet har afsat økonomiske midler som skolerne kan søge til at understøtte arbejdet med handlingsplaner.

Unge i Danmark har lange gennemførelsestider i uddannelserne og en høj dimittendalder. For eksempel er det faktiske tidsforbrug i erhvervsuddannelserne på 7,6 år, mens den normerede tid er på 3,7 år (Undervisningsministeriet 2009). De unge anvender således mere end dobbelt så lang tid, som uddannelserne er normeret til primært på grund af studiepause, som blandt andet skyldes at mange unge afbryder en uddannelse og først efter en pause starter på en anden uddannelse. Blandt andet Velfærdskommissionen (2006) pegede på, at dette er et betydeligt problem i forhold til den forventede demografisk betingede mangel på arbejdskraft. Kommissionen foreslog at bruge den statslige uddannelsesstøtte som redskab til at tilskynde de studerende til at komme hurtigere gennem uddannelsessystemet.

\subsection{Lighed i adgangen til uddannelse og arbejde}

Den frie og lige adgang til uddannelse uanset køn, herkomst, alder og geografi er ikke kun vigtigt af hensyn til den sociale retfærdighed, men er også vigtigt for at sikre arbejdsmarkedet den bedst kvalificerede arbejdskraft. Samfundet har en interesse i at kunne udvikle alle de potentialer, som findes i de opvoksende generationer og at undgå begrænsninger i adgangen til uddannelse og arbejde, som skyldes for eksempel køn, social herkomst og etnicitet. Samfundets ønske om at udnytte den såkaldte „intelligensreserve“ er et vigtigt argument for at reducere sociale skævheder i rekrutteringen til især de videregående uddannelser. Duale systemer, som det danske, indebærer en tidlig opdeling i ungdomsuddannelserne mellem studieforberedende og erhvervsrettede uddannelser. De har endda i Danmark hver deres institutioner, love, styringsformer - og kulturer. I kraft at denne opdeling sker der en social sortering, der begrænser den sociale mobilitet, fordi adgangen til videregående uddannelser 
er begrænset for de unge, der tager en erhvervsuddannelse (Müller 2005; Steedman 2005). Det er også påvist i Danmark, at desto højere uddannelsesniveau forældrene har, desto større chance har barnet for at få en gymnasial uddannelse og ikke en erhvervsuddannelse (Jæger \& Holm 2007). I erhvervsuddannelserne kan man tale om en dobbelt social sortering. Den første sker ved overgangen fra grundskole til ungdomsuddannelse, når de unge deles op på henholdsvis gymnasiale uddannelser og erhvervsuddannelser. Den anden sker i erhvervsuddannelserne ved overgangen fra grundforløb til hovedforløb, når eleverne deles i de elever, der opnår en praktikplads, og de som ikke opnår en praktikplads. Det skyldes de mekanismer, som styrer udvælgelsen af elever ved besættelsen af praktikpladser.

Den sociale sortering har været et argument for at fjerne spordelingen i ungdomsuddannelserne i lighed med det, der skete ved indførelsen af den udelte Folkeskole i 1975 i Danmark. Der er ikke for nuværende planer om at fjerne opdelingen i ungdomsuddannelserne. Det skyldes at erhvervsuddannelserne er en attraktiv vej til arbejdsmarkedet for de mange unge, som ikke er bogligt orienterede, og som ikke sigter mod en videregående uddannelse Komparative studier har vist, at et selvstændigt spor med praktiske og erhvervsrettede ungdomsuddannelser udgør et sikkerhedsnet for de unge, der ikke trives i den almene, studieforberedende skole (Shavit \& Müller 2000). Når eleverne opdeles i forskellige spor afhængigt af deres forudsætninger, kan undervisning blive mere målrettet og effektiv og tilgodese de forskellige elevers behov. I lande som Danmark med et dualt system er erhvervsuddannelserne et selvstændigt og anerkendt alternativ, som har sine egne kvaliteter og værdier i forhold til det „boglige“ spor. Erhvervsuddannelserne søges både af unge, der ikke kan klare de bogligt orienterede uddannelser, og af fagligt stærke unge, som er trætte af den boglige kultur.

\subsection{Lærlingeuddannelsernes styrker og svagheder}

Målt på deres beskæftigelsesfrekvens, mobilitet og fleksibilitet har lærlingeuddannelser, som de danske erhvervsuddannelser, generelt en god kobling til arbejdsmarkedet. Styringen af uddannelserne bygger på en blanding af statslig styring, markedsregulering og en betydelig rolle for 
det faglige selvstyre på både centralt og decentralt niveau („plural governance "og „multiniveau regulering“). Der er både styrker og svagheder ved de forskellige styringsformer, og derfor handler udformningen af et velfungerende styringssystem om at løse nogle styringsmæssige dilemmaer. En stærk centraliseret styring kan sikre en høj grad af standardisering som er vigtig for at sikre mobilitet og overførbarhed („,portability“) af kompetencer. Men den kan samtidig være ufleksibel og dårlig til at imødekomme specifikke lokale kompetencebehov. En decentral styring med vægt på lokale partnerskaber mellem uddannelsesinstitutioner og virksomheder kan reagere hurtigt og fleksibelt på nye kompetencebehov, men risikerer at arbejde med et for snævert og kortsigtet perspektiv. Erfaringerne fra 1970'erne viste at en stærk vægt på statslig planlægning baseret på prognoser og "forecast" af de fremtidige kompetencebehov risikerer at gå fejl i forhold til de hurtige skift og teknologiske omvæltninger på markedet. En stærk vægt på markedet og virksomhedernes efterspørgsel har dog modsat vist sig at skabe en underforsyning af kompetencer i forhold til det samfundsmæssigt optimale (suboptimering).

Det faglige selvstyre (partsstyret) udgør en fordelagtig løsning på uddannelsesplanlægningens dilemmaer, som består i, at hvis staten overlader det til virksomhedernes efterspørgsel og finansiering, fører det til underinvestering. Men hvis staten selv overtager styringen og finansieringen, er der risiko for, at den satser på de forkerte uddannelser og derved fejl- og overinvesterer. Det faglige selvstyre udgør et niveau mellem stat og enkeltvirksomheder, som både er tæt på arbejdsmarkedets aktuelle behov, og som samtidig kan formulere branchens fælles behov for kompetencer, hvilket er en forudsætning for en høj mobilitet på tværs af virksomheder. En stærk inddragelse af parterne i styringen af erhvervsuddannelserne kan sikre en høj legitimitet og ansvarlighed. Det er afgørende for at virksomhederne vil stille praktikplads til rådighed for en vekseluddannelse. Men det faglige selvstyre på arbejdsmarkedet kan også indebære stærke faggrænser, der gør det vanskeligt at imødekomme nye og tværfaglige uddannelsesbehov.

Vekseluddannelser med virksomhedspraktik er meget effektive i forhold til at skabe en høj beskæftigelsesfrekvens og sikre kompetencer der er relevante på arbejdsmarkedet. Men vekseluddannelser har også en række svagheder, ikke mindst mangel på praktikpladser. Det søges løst via 
adgangsbegrænsning til visse uddannelser, tilskud til virksomheder og skolepraktik. Udformningen af erhvervsuddannelsernes indhold indebærer løsningen af nogle dilemmaer i forhold til sammensætningen af kompetenceprofilerne. Den socialisering til arbejdslivet og den vægt på specifikke faglige kompetencer, som traditionelt har kendetegnet lærlingeuddannelserne, har vist sig at give en god integration på arbejdsmarkedet med lav ungdomsarbejdsløshed. De skaber en tæt kobling mellem specifikke erhvervsuddannelser og faglige delarbejdsmarkeder. Men specifikke faglige kompetencer har samtidig vist sig at have en stadig kortere holdbarhed, hvilket taler for at de faglige grunduddannelser skal prioritere nogle almene, personlige og analytiske kompetencer, der formodes at have længere holdbarhed. Men de almene kompetencer, som læres i en skolekontekst, kan være vanskelige at overføre til en arbejdskontekst, og en stor del af de unge som søger ind i erhvervsuddannelserne, er ikke motiveret for traditionel undervisning i almene skolefag. Der mangler viden om, hvordan de kompetencer, der er tilegnet under uddannelsen, faktisk anvendes og omformes i det efterfølgende arbejdsliv, og om hvad der gør at nogle kompetencer er let kan overføres („portable“). Erfaringerne med de danske erhvervsuddannelser modsiger den dominerende tendens til at uddannelsessystemerne søger at styrke de almene kompetencer på bekostning af de specifikke.

Erhvervsuddannelser har generelt indbygget nogle modsætninger og dilemmaer, som skyldes at de skal tilgodese flere forskellige behov og interesser. En model med vekseluddannelse og fagligt selvstyre kan skabe forbindelse og dialog mellem disse modsætninger. I en vekseluddannelse kan disse interesser bringes i dialog og løsninger kan blive forhandlet frem inden for uddannelsens rammer. I en statsligt styret skolemodel (enhedsgymnasiet) bliver det overladt til eleverne selv at forbinde skoleviden med praksis efter uddannelsen - hvis de overlever „praksischokket". I en markedsstyret model baseret på enkeltvirksomhedernes behov og indrettet med korte moduler mangler det kontinuerlige uddannelsesforløb, som kan skabe en helhed ud af den teoretiske og praktiske læring. Som det er sket i England, bliver "training“ og „education“ separeret. Det bliver let til "Just-In-Time“ læring tilpasset virksomheden behov i stedet for livslang læring med udgangspunkt i den enkeltes behov. Modsætningerne i erhvervsuddannelserne kan ikke løses eller fjernes. Men der kan i 
uddannelserne skabes rum for at forbinde de mange forskellige aktører og interesser, som trækker i uddannelserne - i stedet for blot at overlade det til deltagerne eller virksomhederne selv. Det giver den danske model gode muligheder for i kraft af kombinationen af statslig regulering, fagligt selvstyre og et stort spillerum til skoler, virksomheder og elever med hensyn til at tilrettelægge og gennemføre uddannelserne.

Det er et spørgsmål, om det ud fra de danske erfaringer er muligt at pege på nogen „best practice“, som andre lande kan lære af. Den komparative forskning har fremhævet betydningen af „institutionel komplementaritet" i de enkelte landes udvikling (Bosch \& Charest 2008). Det betyder at det afgørende for det samlede systems effektivitet er et godt „match“ mellem det enkelte lands specifikke uddannelses-, arbejdsmarkeds- og beskæftigelsessystemer - og ikke at det enkelte system er udformet på en bestemt måde. Den danske model med vekseluddannelser og fagligt selvstyre kan ikke overføres på lande som Sverige, der historisk har fulgt en anden udviklingsbane (Olofson 2005). Uanset hvordan uddannelse og arbejde kobles i de forskellige lande er der behov for at udvikle nye metoder til planlægning af uddannelserne i forhold til fremtiden på arbejdsmarkedet. Metoderne må overskride de funktionalistiske og deterministiske kvalifikationsanalyser på mindst tre områder: ved at skifte fra et mangelsyn til et ressourcesyn i forhold til arbejdskraften, ved at arbejdskraften inddrages aktivt i udarbejdelsen af analyserne blandt andet gennem deres organisationer og ved at vise hvordan udformningen af uddannelserne kan bidrage aktivt til at udvikle erhvervsliv og arbejdsliv på en måde, der fremmer samfundsmæssige mål om beskæftigelse og et bæredygtigt arbejdsliv. 



\section{Tradisjonelle utfordringer - fornyet interesse}

Håkon Høst, NIFU Nordisk institutt for studier av innovasjon, forskning og utdanning

\subsection{Hva skyldes den nye interessen?}

Den fornyede interessen for planlegging av fremtidens kompetanse i Norden kan ses i sammenheng med en økt interesse for dette internasjonalt, særlig i EU. «New Skills for New Jobs»-initiativet i EU har som mål å bedre prognosene for fremtidens kompetansebehov, bedre samsvaret mellom kompetanse og arbeidsmarkedets behov, og styrke forbindelsen mellom utdanning og arbeid. Beslutningstakerne i de nordiske land blir på ulike måter trukket med i arbeid knyttet til dette initiativet, som det å utvikle bedre prognoser på nasjonalt nivå, som siden kan aggregeres opp på europeisk nivå. I tillegg kommer arbeidet med nye yrkesklassifikasjoner og med et europeisk kvalifikasjonsrammeverk, og også livslang læringsprogrammet.

Den store og vedvarende arbeidsledigheten i Europa, nedbyggingen av tradisjonell industri, overgangen til tjenesteøkonomi, og utfordringene med å skape nye vekst danner noe av bakteppet for initiativene. Systemene for yrkesutdanning og -opplæring i de europeiske landene bærer preg av å være etablert i en periode da industriarbeidet hadde dominans, og mange stiller spørsmålstegn ved om de fortsatt er anvendelige. Samtidig skaper forsøkene på å strømlinjeforme ordningene for yrkesutdanning og integrere dem i felles systemer med allmennutdanning, nye utfordringer.

Nasjonalt standardiserte yrkesutdanninger på dette nivået er historisk sett et relativt nytt fenomen, også i de nordiske land. Tradisjonelt gikk ikke ungdom via utdanning til arbeid på dette nivået, men direkte til arbeid. Supplement til den opplæringen man fikk i bedrift, kom for mange 
etter at man hadde vært i bedrift en stund. I et slikt system var problemer med å fă til match mellom bedriftenes kompetansebehov og ungdommens utdanning ukjente. Bedriftenes behov var selve utgangspunktet. Opplæringen i virksomhetene var ulikt organisert og systematisert mellom bedrifter, bransjer og land. Noen steder var det systematisk rekruttering og opplæring av lærlinger i fag, som siden fikk perioder i skole for å lære allmenn- og yrkesteori. Andre steder gikk man inn i et nærmest livslangt arbeidsforhold $\mathrm{i}$ en bedrift med egne interne arbeidsmarkeder. Parallelt med dette fantes det bransjer som investerte lite i opplæring, og som i større grad baserte seg på det man kan kalle flyktig arbeidskraft.

Selv om alle de nordiske land nå har standardisert sine grunnleggende yrkesutdanninger og i stor grad integrert dem ett, felles nasjonalt system for videregående (upper secondary) opplæring, lever ulikhetene videre, gjerne i form av etablerte rekrutteringsmønstre. Fremdeles finner man sterke innslag av at ungdom og voksne rekrutteres til bedrifter uten forutgående yrkesutdanning. I bedriften får de opplæring i å gjøre en jobb, som i varierende grad er systematisert, og som kan variere fra å være svært bedriftsspesifikk til å være knyttet fag eller yrker med et langt bredere nedslagsfelt, for eksempel gjennom en organisert lærlingperiode. Det offentliges bidrag til opplæringen varierer etter hvilke ordninger bransjen kan trekke på.

Problemet med mismatch mellom utdanning og arbeid kan således i stor grad sies å ha oppstått i kjølvannet av etableringen av nasjonale systemer for grunnleggende yrkesutdanning rettet mot ungdom som ikke hadde vært i arbeid, men som altså skulle forberedes på dette arbeidslivet. Utdanningene, både den skolemmessige og den som finner sted som fagopplæring i bedrift har likevel et bredere syfte enn å dekke umiddelbare behov; den skal også gi et overskudd av kvalifikasjoner som gjør at fagarbeideren både kan benyttes på tvers av bedrifter og møte endringskrav i framtiden. Utformingen og dimensjoneringen av disse utdanningene ut fra arbeidslivets behov vil være en stor utfordring uansett hva slags system man velger for ungdomsutdanning, men de vil arte seg litt ulikt.

Basert på de tidligere kapitlene skal vi i dette sluttkapitlet drøfte en del av de utfordringer vi ser på tvers av de enkelte lands systemer. 


\subsection{Ulike systemer - felles utfordringer?}

Det er vanskelig å snakke om noen felles, nordisk modell som også påvirker hvordan arbeidslivets behov formidles til yrkesutdanningssystemene. Man kan kanskje snakke om noen felles trekk, som på den ene siden arbeidsmarkedspartenes innflytelse, og på den annen betydningen av en velferdsstatlig politikk for lik rett til utdanning for alle og full sysselsetting. Men både vektleggingen av disse momentene, og veldig mye for øvrig er svært forskjellig. De fem nordiske land har ulike systemer for yrkesutdanning, og interessestrukturene rundt yrkesutdanningene er heller ikke like, noe som igjen legger grunnlag for store forskjeller i hvordan arbeidslivets behov formidles. I Danmark og til en viss grad Norge har arbeidslivspartene dessuten tatt mye ansvar for yrkesopplæringen, både når det gjelder organisering, tariffering og økonomi, mens man i de øvrige andre land har sett dette primært som statens oppgave. Den største forskjellen ligger trolig i at arbeidsmarkedene i ulik grad er strukturert av yrker eller fag, og i hvordan disse yrkene er koplet til utdanningssystemet.

\subsubsection{Fagopplæring og spesialisert yrkesutdanning}

Det mest omfattende fag- og lærlingsystemet finner man i Danmark. Et mål på dette finner vi i antallet læreplasser eller praktikpladser som ligger på i overkant av 70 000, inklusive pleieområdet og barnehagesektoren. Tross relativt lik befolkningsstørrelse, er dette om lag dobbelt så høyt som i Norge, som også satser hardt på lærlingordningen. Andelen av et årskull på Island som blir lærlinger er omtrent som i Norge, men læretiden er langt kortere for mange. Dette avspeiler dermed at lærlingorndingen er en dominerende kvalifiseringsform i Danmark, men langt mindre dominerende i Norge og på Island. Man har innslag lærlingordning også i Sverige og Finland, om enn i mer beskjedent omfang. Fagopplæring og lærlingordning bygger på at man har nasjonalt standardiserte læreplaner, og at bedriftene underordner egne spesifikke behov i forhold til en standard som skal gjelde fagområder på tvers av bedriftene. Det finnes imidlertid også spesialisert yrkesutdanning i skole, særlig i Finland og på Island. Der en større del av opplæringen for å kunne utføre et arbeid er bedriftsintern og bedriftsspesifikk, vil det være mest hensiktsmessig med brede yrkesutdanninger fra 
skole. Dette er Sverige et eksempel på. Vi skal se litt nærmere på konsekvensene av disse ulikhetene for kompetanseplanleggingen.

Både i Norge og Danmark har man en fagopplæringsordning basert på at arbeidslivspartene er dypt involvert i styringen. Integreringen av fagopplæringen i de offentlige utdanningssystemer har endret på formen, ikke minst gjennom at flere formelle beslutninger om yrkesutdanningene og fagene er lagt til staten. Dette gjelder begge land, om enn på ulike måter. Fortsatt har imidlertid arbeidslivets parter fortsatt stor innflytelse på utformingen av fag og yrker, både enkeltvis og som et system. Feltet preges i begge land av en konsensustradisjon, og det er svært sjelden at myndighetene går på tvers av partenes innstilling når det gjelder fagutforming. Utforming av mål og innhold i læreplaner gjøres i eller i samråd med faglige utvalg og råd. I Danmark er systemet relativt finmasket, med 48 ulike faglige utvalg basert på grupper av fag etter bransjer, mens det i Norge er rasjonalisert helt ned til 9 faglige råd basert på utdanningsprogrammer i skolen. De norske programmene er delvis basert på bransjer og bransjefamilier, delvis er de enda bredere.

I Danmark har de faglige utvalg en årlig gjennomgang av alle fagområder for å se om disse er oppdatert i forhold til arbeidslivets behov. I Norge, hvor rådene omfatter langt flere fag, skjer gjennomgangen langsommere; planen er at man i løpet av en fireårsperiode skal gjennomgå alle fag innenfor et faglig råds område med tanke på nødvendige revisjoner. For områdene som omfattes foregår det, og har i mange år foregått en systematisk vurdering av kompetansebehovene. Ikke bare er det slik at den opplæring som foregår i skolene skal stå i et tett samspill med etterspørselen fra det arbeidslivet det skal betjene, men i tillegg er opplæringen i arbeidet knyttet til produksjon og tjenesteyting slik den faktisk foregår og er organisert i øyeblikket.

\subsection{Fastsettelse av kompetansekrav ikke nøytralt}

Fastsettelsen av læreplaner og kompetansekrav kan på ingen måte sies å være en nøytral avspeiling av arbeidslivets behov, men skjer ut fra fagenes og arbeidslivspartenes forhandlede interesser, i tett dialog med myndighetene som setter det avgjørende stempel på planene. Denne, svært organiser- 
te og systematiske formen for kompetanseplanlegging kritiseres fra noen hold for å være for rigid. En innvending er at den beskytter visse faginteresser mot framveksten av nye kategorier basert på en annen kompetanseprofil, mens en annen innvending er at fagordningen er for treg med hensyn til å fange opp nødvendige omstillinger. I Danmark resulterte det i at utdanningsmyndighetene benyttet sin ellers svært sjelden anvendte rett til å vedta nye utdanninger over hodet på arbeidslivspartene, da de i 2004 opprette en del kortere yrkesutdanninger for å dekke behov de mente det eksisterende systemet var for dårlig på. En av utdanningene som ble opprettet var vindmølleoperatør en gruppe som er ment skal dekke nye behov i denne raskt voksende, grønne næring. De færreste av de korte yrkesutdanningene ble imidlertid noen suksess, først og fremst fordi søkningen sviktet, noe som også kan ses i sammenheng med at disse utdanningene ikke hadde noen forankring hos partene, og dermed en svakere anerkjennelse. Det er en komplisert prosess å etablere nye arbeidstakerkategorier, og blant de forutsetninger som normalt anses som nødvendige er at det er bred enighet om behovet, at den nye kategorien tilbyr noe de etablerte ikke gjør, og at den aksepteres av de tilgrensende faggrupper. I Norge har man, interessant nok, en lignende sak med utdanning som operatør i nettopp vindkraftindustrien. I utgangspunktet vil en slik gruppe i dagens utdannings- og fagopplæringsordning høre inn under en bredere utdanning rettet mot kraftindustrien. Om noen mener dagens fag ikke dekker den nye delen av kraftindustrien på en fullgod måte, skal dette tas opp gjennom ordinære prosedyrer i det faglige råd for elektrofag. Her har imidlertid ikke den nye vindkraftindustrien foreløpig verken representasjon eller noe stort gjennomslag. Derfor valgte de, representert ved en gruppe relativt nyetablerte virksomheter rundt den landbaserte vindkraftindustien på Sør-Vestlandet, å henvende seg direkte til Kunnskapsdepartementet. Mot ønskene til det faglige råd, gikk departementet inn og åpnet for en egen utdanning rettet mot å bli lærling i denne bransjen. Det er for tidlig å si hva som blir resultatet av dette i form av fagarbeidere og sysselsetting, men saken illustrerer hvordan fagopplæringssystemet er knyttet til etablerte interesser, ofte basert i tradisjonelle bransjer. Man har klart å etablere et samarbeid om kvalifikasjonsprofiler gjennom fag, som langt overskrider den enkelte bedrifts behov, ved at man har enes om et innhold i faget som både fanger noe felles, men som sett fra den enkelte bedrifts ståsted også er preget av en grad av overskudd av kvalifikasjoner, 
eller redundans. Når næringslivet utvikler seg, og nye næringer utfordrer gamle, slik tilfellet er i kraftindustrien, vil ikke det faglige råd nødvendigvis representere hele bredden av interesser. Tendensen vil være at det faglige råd er konservativt, ikke alene basert på at de representerer det bestående innenfor en gitt næring, men også ved at de er tilbakeholdne i forhold til å endre forhandlede fagutdanninger og faggrenser før de er overbevist om at det er et faktisk behov og grunnlag for dette. Kunnskapsdepartementet, på sin side, kan antas å ha et ønske om å være åpne for nyskapning, eller i hvert fall ikke å bli beskyldt for å hindre dette, og valgte derfor i dette tilfellet å gå mot arbeidslivspartene og det faglige råds anbefalinger. En slik framgangsmåte kan imidlertid neppe gjentas ofte uten at det setter forholdet til arbeidslivspartene på spill.

Vi viser ellers til kapitlet om pleie- og omsorgsutdanningene som viste at dette feltet er sterkt preget av interesser som farger definisjonen av hva som egentlig er arbeidslivets behov.

\subsection{Kunnskapsklynger som alternativt utgangspunkt?}

En annen og lignende innvending går på at fagene og de faglige utvalg og råds avgrensning ut fra tradisjonelle bransjeoppdelinger ikke fanger den mer dynamiske utviklingen i deler av arbeidslivet, men at denne bedre kan fanges gjennom å ta utgangspunkt i såkalte clusters, eller klynger. Mange mener det er her den viktige innovasjonen skjer for deler av næringslivet, og at denne ikke kan fanges av fagenes rådsordning innenfor fagopplæringen. Dette er heller ingen enkel sak å bedømme, ikke minst fordi det er uklart hva som er å betrakte som en klynge. Mens det opprinnelig var å forstå som en geografisk avgrenset gruppe bedrifter som på ulike måter samarbeidet og styrket hverandre, har mange av klyngene utviklet seg til å omfatte bedrifter på tvers av til dels store områder, og også land. Dermed får man store utfordringer i, både i forhold til å avgrense hvem som er legitime representanter for ulik områder og interesser, og hvordan et slikt system skal tilpasses nasjonalt standardiserte systemer. I Finland har man i kompetanseplanleggingen basert seg på en kunnskapsklynge-tilnærming. Innenfor hver av klyngene blir ulike aktører og interessenter med ekspertise trukket med for å diskutere hva som er behovet, 
og man benytter en rekke kunnskapskilder. Også organisasjoner og fagforeninger knyttet til klyngene inviteres til å komme med egne prediksjoner som kan integreres i arbeidet. En innvending mot klyngekonseptet er at avgrensingen er svært uklar. Det finnes for eksempel fagfelt som er knyttet til nesten alle klyngene. Hvordan interesserepresentasjonen og avveiningen skal skje mellom disse er ikke enkelt.

Kan lærlingordning gi bedre samsvar med arbeidslivets behov i nye områder?

Det foregår en dreining mot bruk av arbeidslivet som opplæringsarena i hele Europa. Dette omfatter ikke bare de grunnleggende yrkesutdanninger, men også høyere utdanning. Det er rimelig å se de svenske initiativene med å etablere en lærlingordning i tilknytning til den gymnasiale yrkesutdanningen som en del av denne tendensen. Denne dreiningen bærer i seg mange aspekter, både det å bruke arbeidslivet som en mer virkelighetsnær opplæringsarena for de som ikke opplever ren skoleopplæring som motiverende, det å hjelpe ungdom til å få fotfeste i arbeidslivet, og det å bidra til at yrkesutdanningene kommer tettere på arbeidslivets behov. For Sveriges del, med en svært høy ungdomsarbeidsledighet relativt til den totale ledigheten, er trolig alle disse aspektene viktige. Det som i denne sammenheng er særlig interessant er hvordan en svensk lærlingordning kan bidra til en mer effektiv formidling av arbeidslivets behov til utdanningssystemene. Det pekes på utfordringer i Sverige, både i form av frafall i utdanningen, stor ungdomsledighet, og - i følge arbeidsgiverne - i form av at de som er ledige i stadig mindre grad matcher det som finnes av ubesatte jobber. Som ved de fleste reformer, har ulike aktører forskjellige mål med den, og lærlingordningen kan slik sies å skulle bøte på alle de ovenfor nevnte problemene. Det pekes likevel allerede på visse svakheter ved det svenske lærlingforsøket. Den største er trolig at det i for stor grad har en sosialpolitisk innretning, gjennom en særlig vektlegging av at ordningen skal hjelpe de mest utsatte gruppene. Dessuten er det slik at bedriftenes engasjement i lærlingforsøket har vært moderat. Lærlingene er utplassert i opplæring, men blir ikke ansatt i bedriftene, og felles organer mellom partene i arbeidslivet og skolene som kan bidra til å sikre kvaliteten på opplæringen, og sikre sammenheng mellom opplæring i skole og opplæring i arbeidslivet er svakt utviklet. Utgangspunktet er ikke enkelt; man har i Sverige i langt mindre grad enn i Norge og Danmark, 
yrker med en dominerende posisjon innenfor sitt arbeidsfelt. Det som tradisjonelt framheves som en styrke ved lærlingordninger er nettopp korrespondansen mellom opplæringsprogrammer i skole og fag eller yrker i bedriftene. Dette har vært sikret ved at arbeidslivets parter har spilt en sentral rolle i å fastlegge opplæringsplaner for de ulike fag og yrker. Arbeidsdelingen mellom skole og bedrift kan variere i ulike modeller. Man kan ha kortere eller lengre opplæring i skole, og man kan ha bredere eller smalere fag. Men man er avhengig av både avtaler mellom partene om hvordan disse kategoriene skal utformes, og ha kvalitetssystemer for disse som både arbeidslivet og utdanningssystemet har tillit til og aksepterer. Bare på den måten vil bedriftene etterspørre lærlinger og anvende ferdig utdannede fagarbeidere.

Mens det danske lærlingsystemet tradisjonelt har hatt en meget sterk stilling, er dette ikke tilfellet med det norske. Så sent som på 1970-tallet var lærlinger en relativt marginal gruppe i arbeidslivet og i opplæringssammenheng. Ordningen vokste utover 1980-tallet gjennom at bedriftene i økende grad sikret sin rekruttering ved å ta inn lærlinger, og gjennom Reform 94 vedtok man et nytt system for yrkesutdanning hvor lærlingordningen skulle være en hovedpilar og dekke hele arbeidslivet. Ungdom skulle kunne søke seg til utdanninger rettet mot alle sektorer av arbeidslivet, og bedrifter skulle kunne rekruttere lærlinger ut fra behov. Dette har bare lykkes halvveis. Den moderniserte lærlingordningen koplet til videregående opplæring i skole, har etter dette konsolidert seg i de tradisjonelle kjerneområdene for fag og fagopplæring, nemlig $\mathrm{i}$ håndverksfagene og $\mathrm{i}$ store deler $\mathrm{av}$ industrien. Innenfor de store og arbeidskraftkrevende områdene i offentlig tjenesteyting og privat service, er det imidlertid slik at ordningen, nesten 20 år etter reformen, sliter hardt med å finne fotfeste. Problemene er sammensatte, og av ulik karakter. I offentlig tjenesteyting har man som vist i kapittel $\mathrm{xx}$, en tradisjon for yrker, men ikke for å rekruttere verken lærlinger eller ungdom. Her er dessuten problemet at andre interesser enn fagopplæringens bidrar til at arbeidskraftbehovet blir formet i profesjonenes bilde, og at fagutdanningen som eksisterer, ikke er attraktiv for ungdom. Dermed omdefineres rekrutteringsbehovet på ny, nå i tråd med søkermønsteret. I privat service, som f.eks. varehandelen har man tradisjoner for å rekruttere ungdom, men ikke som lærlinger eller til fag og 
yrker. I begge disse sektorene er arbeidslivets parter med og gir lærlingordningen legitimitet, men ordningen er ikke attraktiv blant de unge. Ikke minst av den grunn er bedriftene nølende i forhold til å satse på lærlinger framfor å rekruttere ufaglærte for intern opplæring som de alltid har gjort. Dette bidrar til å svekke fagopplæringens rolle i fastsetting av arbeidskraftbehovet. Læreplaner blir i større grad utdanningssystemets ansvar, og forankringen i arbeidslivet blir svak. Virksomhetene lærer opp nyansatte slik de har hatt tradisjon for, uavhengig av disse læreplanene. Skolene på sin side rekrutterer årlig tusenvis av ungdommer til yrkesutdanningsprogrammer, men hvor bare en liten andel bruker denne utdanningen til å bli lærlinger i de aktuelle fag. Frustrasjonen øker, også hos myndighetene, og det reises spørsmål ved hele ordningen.

\subsection{Er tilbud om læreplasser et uttrykk for arbeidslivets behov?}

I Norge er tilbudet av læreplasser et viktig parameter i arbeidet med å dimensjonere yrkesutdanningen i skole. I de fag hvor det er langt flere søkere enn det beregnede tilbudet på læreplasser, kan fylkeskommunene dimensjonere ned skoletilbudet. Dette er effektivt i de fag hvor hovedinngangen går gjennom hovedmodellen med to år i skole før læretid. Dette utgjør likevel et mindretall av fag. I de aller fleste er situasjonen omvendt, nemlig at det mangler søkere, slik at søkningen i realiteten styrer dimensjoneringen. I Danmark er dette noe annerledes, fordi kandidater som har skaffet seg læreplass eller praktikplads har krav på skolegang. Det betyr at bedriftene selv dimensjonerer utdanningene. Unntaket er de tilfeller hvor myndighetene vedtar å etablere skolepraktik for de elever som ikke klarer å skaffe en læreplass. Da kan de benytte dette i dimensjoneringen. I hvilken grad er så tilbudet om læreplasser et uttrykk for arbeidslivets behov for rekruttering og kompetanse? For Danmarks vedkommende vises det til at visse, særlig håndverkspregede bransjer, og mindre bedrifter, tar inn et overproporsjonalt antall lærlinger i forhold til hva de trenger, fordi det er lønnsomt å benytte dem som arbeidskraft i læretiden. Et lignende fenomen er kjent i Tyskland, hvor bilfabrikken Opel en tid hadde ord på seg for å være den bedrift med flest bakere, men da ansatt som spesialarbeidere i produksjo- 
nen av biler. For Norges del finnes det ikke forskning som kan sannsynliggjøre noe lignende. Problemstillingen er imidlertid høyst reell også her. Selv om tradisjonen har vært at ansettelse av lærlinger har vært sett på som rekruttering ut fra bedriftens behov, kan dette opplæringsforholdet både være vurdert i et kortsiktig og et langsiktig avskrivningsperspektiv.

Tilgangen på læreplasser er et viktig styringsparameter, men samtidig har et lærlingsystem behov for bedrifter som tar inn et overproporsjonalt antall lærlinger for å kompensere for de bedriftene som ikke tar inn nok, og også for å dekke opp elevenes behov for at det til en hver tid skal være nok opplæringsplasser. Dette var bakgrunnen for at norske myndigheter i forbindelse med Reform 94 betonte at lærlinginntak skulle være utdanning, ikke rekruttering. Dersom sammenhengen mellom lærlinginntak og rekrutteringsbehov blir for svak, kan imidlertid dette også skape problemer.

\subsection{Island: Store svingninger gjør planleggingen utfordrende}

På Island har man også fagutdannelse og lærlingordning. Her har imidlertid fagene en langt større grad av fleksibilitet med hensyn til kombinasjonen av skole og læretid. Det betyr at de mest teoretiske av yrkesfagene, innenfor elektrområdet, har en skoledominert utdanning med kun et par semestres lærlingtid, mens de mest praktiske fagene, for eksempel innen næringsmiddelproduksjon har det motsatt, med kort skoletid og lengre læretid. Et annet særtrekk ved forbindelsen mellom yrkesutdanning og arbeidslivet er at den utenlandske storindustrien innenfor metallområdet, ikke har ønsket å bidra til etableringer av yrkesutdanninger knyttet til utdanningssystemet. De foretrekker bedriftsintern opplæring, hvilket betyr at de rekrutterer folk med generelle utdanninger. Den bedriftsinterne opplæringen gjør at de ansatte i mindre grad vil kunnevære mobile på arbeidsmarkedet. Totalt sett er bildet at en større del av ungdommen på Island tar allmennutdanning, samtidig som ungdom er mer arbeidsorientert enn i de øvrige nordiske land og dermed velger jobb framfor videregående opplæring når tidene er gode og innbyr til det. Landets begrensede befolkning har dannet grunnlag for en tro på at man har god oversikt, og kan snu seg raskt når arbeidslivets behov endrer seg. De dramatiske og 
ofte uforutsigbare skiftningene i landets økonomi, både som en naturlig følge av forholdene i den tradisjonelle fiskerinæringen, og som følge av de i større grad sosialt skapte systemproblemene i finanssektoren, har da også gjort islendingene vant til brå skifter.

Det betyr imidlertid ikke at man ikke har forsøkt å planlegge. På 1970tallet bygde man ut yrkesutdanningene på grunnlag av en politikk for satsing på industri. Dette lyktes ikke, og i stedet endte man opp med at ungdommene dekket den økte etterspørselen i byggebransjen og servicesektoren. I dag har man tre konkurrerende scenarier for de kommende år, dels basert på ulike interesser; noen går for satsing på nyinvesteringer $\mathrm{i}$ kraft og storindustri, andre peker på veksten små høyteknologiske software-produserende virksomheter, mens en tredje retning vil støtte opp om den såkalt grønne veksten. I lys av denne usikkerheten, er det både blant arbeidslivspartene og politikerne en vilje å satse på å heve det generelle kompetansenivået. Både arbeidsgivere og fagbevegelsen deltar aktivt i rådene som står for utformingen av yrkesutdanningene. Disse har nå blitt enige om å styrke lærlingordningen gjennom at det skal opprettes et sentralt fond som kan finansiere lærlingtilskudd til bedriftene.

\subsection{Den finske «prognoseindustrien»}

I den internasjonale litteraturen knytter som regel man ulike yrkesutdanningsmodeller til kjennetegn ved arbeidsmarkedene. Der arbeidsmarkedene er strukturert av yrker, vil en som regel finne utdanningssystemer som i stor grad spesialiserer mot de samme yrker. Ofte er dette kombinert med en eller annen form for lærlingordning, slik vi særlig ser det i Danmark og Norge. Dette gir arbeidslivet og bedriftene en avgjørende innflytelse på utdanningenes og fagenes profil til en hver tid. I Finland har man imidlertid kombinert yrkesspesifikke arbeidsmarkeder og et yrkesutdanningssystem preget av sterk spesialisering, men i all hovedsak med skolebaserte utdanninger. Så lenge bedriftene ikke tar inn lærlinger i særlig omfang, mister man dermed den direkte reguleringen arbeidslivet representerer. Det å finne andre mekanismer som kan kompensere dette, og å tilpasse utdanningene til arbeidslivets behov har således stått på dagsorden helt siden yrkesutdanningssystemet ble etablert. Det har resultert i et 
stort antall prosjekter, organer, tiltak og modeller rundt det som gjerne kalles «prognoseindustrien».

Sentral arbeidskraftplanlegging har en lang og sterk tradisjon i Finland. Det nye er forsøket på å utforme mer raffinerte metoder. Kanskje som en følge av dette er også Finland det av de nordiske land som har vært mest engasjert i EUs arbeid med framskrivninger av arbeidsmarkedsbehov, og man har iverksatt flere prosjekter på dette feltet basert på finansiering fra EUs sosial fond. Ett av disse prosjektene arbeider for å utvikle et rammeverk for kvalifikasjonsscenarier som kan anvendes på alle yrkesfelt og -nivå. Systemet er svært fingreinet; for hvert yrke skal det utvikles en nøkkel hvor arbeidsmarkedsbehovet oversettes til faktisk output fra utdanningssystemet, både kvalitativt og kvantitativt. Problemet som påpekes i forhold til dette er at forholdet mellom utdanning og arbeid aldri er 1:1. Også i et slikt system er det utfordringer med å få inn nye fagfelt, fordi man i stor grad baserer seg på ekstrapolering av kjente trender. Prognostiseringen er blitt svært kompleks og omfatter enn rekke berørte aktører og interesser, og ble således av den finske Riksrevisjonen kritisert for å være nærmest ugjennomtrengelig. Systemets feedback kommer fra arbeidslivet i form av sysselsettingsfrekvenser. Som følge av substitusjonseffekter, er det ikke enkelt å si i hvilken grad dette er et valid mål på det å utforme yrkesutdanningen på grunnlag av framtidsprognoser.

\subsection{Mange felles tiltak}

Vi ser at det gjøres ulike tiltak for å gjøre utdanningssystemene bedre rustet til å respondere på fremtidens kompetansebehov. Veldig grovt kan disse tiltakene summeres under tre hovedpunkter:

- Mer generell utdanning sik at ungdom er best mulig rustet for et uforutsigbart og omskiftelig arbeidsliv

- Bruk av lærlingordninger for å sørge for at opplæringen ligger tettere på bedriftenes behov

- Større anstrengelser for å få til en mer treffsikker beregning av behov 
De ulike landene ser alle sammen ut til å ta i bruk samtlige av disse tiltakene, men blandingsforholdet er ulikt. Dette avspeiler i stor grad at man ikke har like systemer i utgangspunktet.

Island, som har erfart store svingninger, heller mot et mer generelt system, som baserer seg både på yrkesopplæring i skole og lærlingordning, samtidig som man streber etter bedre måter å skape bedre forutsigbarhet på gjennom planlegging.

Finland, som opplever stor ungdomsarbeidsløshet, forsøker å raffinere sine metoder for å tilpasse sine spesialiserte skoleutdanninger til arbeidslivets behov gjennom bruk av avanserte prognose- og antisiperingsverktøy, men også gjennom å mobilisere en rekke ulike aktører i arbeidet med planene.

Sverige, som også preges av særdeles høy ledighet blant ungdom spesielt, forsøker ut en lærlingordning innenfor sitt system av relativt brede yrkesutdanninger. Hensikten er å minske avstanden mellom nærings- og arbeidslivet og skolen.

Danmark har fortsatt tro på sin lærlingordning, og prioriterer særlig det å skaffe flere lærlingplasser. Samtidig satser de på fortløpende å tilpasse de eksisterende lærlingutdannelser til endringer i arbeidslivet, og å gjøre lærlingeutdannelsene mer attarktive for ungdom.

Norge satser også særlig på lærlingordningen, men har gjort yrkesutdanningene bredere i et forsøk på både å gi elevene større valgmuligheter og fleksibilitet, og for å gi bedriftene et bredere rekrutteringsgrunnlag når de skal ta inn lærlinger.

De ulike tiltakene møter alle utfordringer. Det å etablere bredere utdanninger skaper erfaringsmessig motivasjonsproblemer hos en del av ungdommen, som ikke ser relevansen av det de skal lære. Mer generell utdanning betyr vanligvis også en mer teoretisk utdanning. Dermed svekkes motivasjonen ytterligere hos mange. I utdanninger som tradisjonelt er rettet mot spesifikke yrker, vil også lærerne i utgangspunktet være kvalifisert med bakgrunn i sitt yrke, og en omlegging fra fagspesifikke til bredere programmer skaper store utfordringer. Gjennom evalueringen av reformen Kunnskapsløftet i Norge er konklusjonen at det ikke er mulig å se tegn til at bredere utdanningsprogrammer har bedret tilpasningen til arbeidslivet i form av læreplassoverganger. Det er foreløpig liten entusiasme å spore hos bedriftene for denne dreiningen, ikke minst fordi en mer generell skoleopplæring impliserer en større opplæringsbyrde på bedriftene. 
Større bruk av lærlingordning for å tilpasse utdanningene til bedriftenes behov er en sterk trend i Europa, og i Sverige forsøker man dette på alvor. Det er alt for tidlig å si hvordan dette forsøket ender, men en svak forankring av reformen blant bedriftene vekker bekymring. Erfaringene fra Norge viser at det å etablere fag og lærlingordning i områder av arbeidslivet der dette ikke har noen tradisjon, er meget komplisert. Snart 18 år etter Reform 94 står fagopplæring fortsatt svakt i de områdene man den gangen forsøkte å utvide lærlingordningen til, som for eksempel sentrale områder av tjenestesektoren.

Det å bedre verktøy og metoder for å kunne planlegge for fremtidens kompetansebehov er viktig for alle landene. De bidrar derfor med nasjonale tall til EU for framskrivninger av arbeidsmarkedet. Dette arbeidet er imidlertid ikke like tett koplet på arbeidet med yrkesutdanningene i de enkelte land. I Danmark, Norge og på Island skjer arbeidet med vurdering av kompetansebehovene først og fremst i tilknytning til de etablerte fagene og fagrådene innenfor fagopplæringen. En utfordring kan være at disse er forankret i tradisjonelle og interessebaserte fagoppdelinger, og dermed enten ikke oppfatter eller beskytter seg mot nye og konkurrerendekompetanseprofiler. En annen er at lærlingordningen og det enkelte faglige råd ikke i tilstrekkelig grad representerer de dominerende rekrutteringsmønstre innenfor sitt felt. I Finland, «prognoseindustriens» hjemland, forsøker man å overskride disse problemene ved å samle aktører med utgangspunkt i såkalte kunnskapsklynger. En av utfordringene vil da være hvem som skal anses å være legitime representanter for dette arbeidsfeltet, men også hvordan kunnskapsklyngene er avgrenset i forhold til yrkesutdanningene både nasjonalt og regionalt.

\subsection{Hva slags og hvor høy utdanning er det behov for?}

Selv om vi i denne rapporten har konsentrert oss om yrkesutdanninger på videregående nivå (upper secondary), eksisterer ikke dette området i et vakum. Det er vesentlig å forstå dem i forhold både til de ufaglærte nedad og til arbeidstakere med høyere utdanning oppad. I Sverige har sterke røster fra næringslivet hevdet at overutdanning er et problem; Ungdom med høyskoleutdanning går inn i jobber som ikke burde kreve mer enn 
utdanning fra videregående. En mulig fortolkning er at stor ledighet gjør at de med høyest formell utdanning blir foretrukket av bedriftene, fordi ungdom med videregående yrkesutdanning ikke har noen lærlingordning eller andre mekanismer som gjør dem attraktive eller kopler dem til bedriftene. I så tilfelle styrker det bildet av et system hvor avstanden mellom yrkesutdanningene og det arbeidslivet det skal betjene er et problem. Dermed får man en substitusjonseffekt hvor de med lengst utdanning får jobbene, uten at de nødvendigvis er yrkesmessig bedre kvalifisert.

I de danske prognosene ser man et fall i tilbudet av faglærte de nærmeste 10 år, både i pleie- og omsorg og i finanssektoren. På det sistnevnte området mener man nedgangen i faglærte kan substitueres av personer med høyere utdanning, som ventes å stige raskt i samme periode. Her ser vi som i den norske pleie- og omsorgssektoren hvordan arbeidslivets «behov» defineres ut fra tilbudet av utdannet arbeidskraft. Om disse jobbene er attraktive for denne gruppen, slik at de faktisk fyller stillingene, gjenstår å se.

Det argumenteres på lignende måte når det gjelder å rekruttere til pleie og omsorgssektoren i Norge som omtalt i kapittel 6. Det virker imidlertid urealistisk, både i Norge og i de andre nordiske land å substituere personalet med grunnleggende yrkesutdanning med høyskoleutdannet personell. Det er snakk om et meget høyt antall personer, og basert på de nåværende rekrutteringsmønstrene er det grunn til å stille spørsmålstegne ded om dette vil skje.

Men alle de tre eksemplene peker på noen utfordringer for yrkesutdanningene. Dersom de mister sin attraksjon, enten hos arbeidsgiverne eller søkerne, vil de kunne bli erstattet av andre grupper, enten med høyere eller lavere utdanning.

\subsection{Koplinger til allmennutdanningen. Styrke eller trussel?}

Det er samlet en klar tendens i de nordiske land til ungdom i økende grad søker studieforberedende i stedet for yrkesfaglig utdanning. I Danmark søker de unge seg i stigende grad til de studieforberedende utdanningene, blant annet fordi lærlingutdanning ikke gir studiekompetanse for høyere utdanning. Nå er man i ferd med å etablere en kombinert yrkes- og all- 
mennutdanning. I Norge har man noe lignende i TAF-ordningen, som er relativt beskjeden av omfang. Derimot har vi en ordning som store deler av arbeidslivet fortviler over, nemlig den såkalte påbygning til generell studiekompetanse. Fra å ha vært en sikkerhetsventil for ungdom som hadde valgt yrkesutdanning, men ombestemte seg underveis. Nå er dette i ferd med å bli en hovedvei gjennom videregående opplæring. I flere fylker er det nå like mange av de starter opp på en yrkesutdanning som siden avbryter for å sikre seg studiekompetanse, som det er som velger å bli lærlinger. I Sverige går man andre veien og fjerner den studiekompetanse yrkesutdanningene tidligere ga. Foreløpig ser resultatet ut til å være et ganske dramatisk fall i yrkesutdanningenes søkertall.

Vi har for liten forskning på feltet til å kunne si at dragningen mot studiekompetanse gir uhensiktsmessige mønstre for de ungdommene som i utgangspunktet søkte yrkesutdanning, eller at det nødvendigvis er lite rasjonelt sett fra arbeidslivet side. På ulike vis må en anta at ungdom oppfanger signaler om muligheter og barrierer i ulike deler av arbeidsmarkedet, og at deres gradvise utdanningsvalg avspeiler nettopp dette. De signalene de oppfatter kan være at i visse bransjer klarer man seg vel så godt med en mer generell utdanning, som en fagutdanning, som for eksempel i varehandelen i Norge. På den annen side kan det også være at ungdom oppfatter at de læreplasser som tilbys er for lite attraktive, eller tilbys bare noen steder. Servicesektoren har ikke samme tradisjon for læreplasser som industri og håndverk har, noe som åpenbart er en utfordring når servicesamfunnet blir det dominerende. Valg av studeiforberedende utdanninger kan også avspeile at høyere utdanning ses som mer egnet enn yrkesutdanning innenfor det felt de søker seg mot, som for eksempel i helse og sosialsektoren, omtalt i kapittel 6.

Eksemplene berører også noe som gjelder alle de nordiske systemene; det er vanskelig nok å enes om et framtidig behov for ulike former for kompetanse. Når man eventuelt enes, så får det ofte liten effekt fordi våre systemer i så stor grad er etterspørselstyrte. Det at ungdom i stor grad kan velge hvilken yrkesutdanning de ønsker seg, eller om de slett ikke ønsker denne form for utdanning gjør at bransjene i stor grad må rette seg etter dette. De har derfor sin kanskje aller største utfordring i å etablere attraktive utdannings- og opplæringsordninger. 


\subsection{De voksne som avgjørende ressurs for arbeidslivet}

De nordiske land har hatt et veldig sterkt fokus på ungdom i sin utdanningspolitikk. Man har hatt behov for å få orden på de grunnleggende systemene for utdanning på videregående nivå. Spesielt i Norge og Sverige førte den store statsingen på ungdom til at tilbud til voksne ble sterkt nedprioritert. Senere har man gjennom nye reformer forsøkt å bøte på dette igjen. På Island kan krisepolitikken føre i samme retning. I alle landene er imidlertid utdanningsordninger for voksne svært viktige både for arbeidslivet, for voksne enten de er arbeidstakere eller står utenfor arbeidslivet, og ikke minst for økonomien. Enkelte store sektorer, som for eksempel pleie og omsorg, er til og med dominert av voksne i alle de nordiske land. Både her og i mange andre bransjer rekrutterer man i stor grad voksne, men uten at disse nødvendigvis har yrkesutdanning rettet mot den aktuelle bransje. I andre bransjer har voksne behov for faglig oppdatering eller videreutvikling. Etablering av utdanningstiltak for voksne, enten det dreier seg om grunn, etter- eller videreutdanning vil være svært sentralt om arbeidslivet skal få dekket sine behov i fremtiden. Her vil bedriftenes behov kunne uttrykkes mer direkte ut fra hva de har av ansatte med behov for fagutdanning. Samtidig må det forhandles med det offentlige om hva utdanningsbehovet er, og hvem som skal organisere og finansiere dette. Som i alle ledd av kompetansepolitikken vil det også her være snakk om ulike kombinasjoner av stat, marked og partsinteresser.

\subsection{Utfordringene}

Det er svært vanskelig på grunnlag av et såpass komprimert arbeid om et så omfattende og komplekst felt å gi veldig klare anbefalinger. Vi har gruppert de mest sentrale tiltakene vi finner for å styrke forbindelsen mellom arbeidslivets behov og utdanningssystemets utforming i tre:

- Vendingen mot å benytte arbeidslivet som opplæringsarena, særlig i form av lærlingordninger

- Utforming av bredere og mer generelle yrkesutdanninger i skolen 
- Styrking av arbeidet med prognoser og kvalifikasjonsanalyser

Som vi har sett er ingen av disse tiltakene universalmidler. De har styrker og svakheter. Lærlingordninger er i skuddet for tiden, og kan selvfølgelig vedtas, men det er en komplisert og langvarig prosess å få de til å bli effektive, og det behøver ikke lykkes. I enkelte deler av arbeidslivet i Norge har man forsøkt snart i 20 år uten at man kan spore særlig framgang. Mange behov dyttes på en lærlingordning, ikke bare det å utvikle gode fagarbeidere. Om man overlesser en lærlingordning med sosialpolitiske og andre mål, kan man risikere at verken ungdom flest eller bedriftene finner den interessant. Bredere yrkesutdanninger kan gi ungdom en mulighet til å utsette valg, og det kan også gjøre at arbeidslivet får et større rekrutteringsgrunnlag. Samtidig kan det også bety svakere fagidentifikasjon og svekket motivasjon hos elevene. Dessuten vil elever med altfor generelle kunnskaper ikke være attraktive i alle bransjer. Større vekt på arbeid med prognoser og kvalifikasjonsanalyser har denne fordelen at de øker bevisstheten rundt planlegging. Samtidig ligger det alltid en fare i at man glemmer begrensingene. Jo mer sofistikerte og elegante modellene blir, dess større er tendensen til at prognosene blir sett på som en avspeiling av virkeligheten. Derfor må en aldri miste av syne at prognoser - uansett mål om mest mulig objektivitet - alltid vil være preget av forutsetningene man legger inn. Disse forutsetningene er basert på ulike interesser og mål, i tillegg til de usikkerhetene som råder om en rekke forhold som vil påvirke utviklingen framover.

Det finnes ikke ett universalmiddel i arbeidet med å øke utdanningssystemenes responsitivitet overfor arbeidslivets behov. Et land vil måtte benytte ulike kombinasjoner av de omtalte tiltak, og dette må være fundert i de tradisjoner og forutsetninger de ulike land har.

Et aspekt som er berørt i flere av bidragene handler om at arbeidslivets behov også må ses som en nødvendig respons på tilbudet. En overgripende tendens i dag er at ungdom i større grad søker seg mot studieforberedende utdanninger. Men detfinnes også andre tendenser. En er at ungdom spm søker yrkesutdanning, i stor grad ønsker yrkesspesialisering og praksis. Begge deler kan både ses som uttrykk for ungdoms egen tolkning av arbeidsmarkedets utvikling, og som et signal til arbeidsmarkedet om ungdoms ambisjoner og ønsker. I alle tilfeller setter det yrkesutdanningene og 
arbeidslivet under et press i retning av å utforme og tilby utdanninger og jobber som tiltrekker seg søkere. Dette er ikke en særlig utfordring for Norden, men en global tendens. Selv i masseproduksjonens Kina hvor majoriteten av jobber fortsatt er å finne i landbruk og industri, er det bare to prosent av kinesiske foreldre som ser for seg at dere barn skal jobbe i disse sektorene ${ }^{73}$, som i dag ikke forbindes med utdanning og utvikling.

Det gir ytterligere mening til påstanden om at bedriftene også må tilpasse sine behov, dvs. utforme jobbene, i forholdet tilbudet av arbeidskraft. Dette er imidlertid ikke noe helt nytt, annet enn kanskje i formen. Bak ideen om fag og yrker ligger det historisk også en ambisjon om å utvikle selvstendige yrkesutøvere som selv er med på å forme sitt eget arbeidsområde.

${ }^{73}$ Jon Pedersen, ved forskningsstiftelsen Fafos Kina-kontor til Aftenposten 2.11.2011. 



\section{Referanser}

2009 EU-China High Level Round Table on Social Security (2009). Stockholm October. http://www.eucss.org.cn/fileadmin/content/activities_and_events/ Round_Table/Roundtable_2009.pdf

Act 630/1998. Laki ammatillisesta koulutuksesta [Vocational Education Act]. (see http://www.finlex.fi/en/)

Act 631/1998. Laki ammatillisesta aikuiskoulutuksesta [Vocational Adult Education Act]. (see http://www.finlex.fi/en/)

AE Rådet, Arbejderbevægelsens Erhvervsråd 2008, Mangel på uddannet arbejdskraft i fremtiden, http://www.ae.dk/files/Mangel-paa-udd-arbejdskr-ae.pdf

AE Rådet, Arbejderbevægelsens Erhvervsråd 2010. Kriser får nyuddannede til at droppe deres fag - det koster i lønposen, www.ae.dk

AE Rådet, Arbejderbevægelsens Erhvervsråd 2011. Studenterhuen giver ingen jobgaranti. www.ae.dk

AER 2010. Erhvervsuddannedes beskæftigelsesfrekvens, ATP erhvervssikring, Arbejdsgivernes elevrefusion. www.atp.dk

Ahola, S. 2006. "You can't go short on bricks". Problems with work-based learning in Finnish AMKs. Paper presented at the Annual SRHE Conference 2006. Brighton, UK, December 12-14.

Allmendinger, Jutta (1989): Career Mobility Dynamics. A comparative Analysis of the United States, Norway, and West Germany. Max Planck-Institut für bildungsforschung: Berlin.

Ainsworth, J.W. och Roscigno, V. J. (2005), "Stratification, School-Work Linkages and Vocational Education", Social Forces, 84 (1), s. 257-284.

Andersen, S. K. (2010), Responses to Growing Unemployment and Mismatch between Skills and Job Openings in EU Member States. Employment Relation Research Centre (FAOS). University of Copenhagen.

Andersson, J. (2010), „Fler män än kvinnor byter jobb”, i Välfärd nr 3.

Anker, Niels 1998: Eleverne, virksomhederne og de nyudlærte: Private virksomheders beskæftigelse af elever og praktikvirksomhedernes betydning for nyudlærtes chancer på arbejdsmarkedet. København, Handelshøjskolen i København.

Ashton, D. och Green, F. (1996), Education, Training and the Global Economy. Cheltenham: Edward Elgar.

Ashton, D., Sung, J. och Turbin, J. (2000), "Towards a Framework for the Comparative Analysis of National Systems of Skill Formation", International Journal of Training and Development, 4 (1), s. 8-25. 
Att söka men inte finna (2010). Svenskt Näringslivs rekryteringsenkät 2010, del 1. Stockholm.

Baethge, Martin,1998: Bildung und Beruf - modern contradictions under postfordist conditions? i Sakslind, Rune (red) : Danning og yrkesutdanning : utdanningssystem og nasjonale moderniserings-prosjekter, Norges forskningsråd Forlag. KULTs skriftserie 103.

Bassanini, A. \& Marianna, P. (2009), Looking Inside the Perpetual-Motion Machine: Job and Worker Flows in OECD Countries. OECD Social, Employment and Migration Papers No. 95.

Betänkande 2009/10:UbU11 Vuxenutbildning

Bjerre, Markus \& Charlotte Kjeldsen 2010: Erhvervsklynger, jobfunktioner og uddannelse - en prognosemodel for fremtidens erhvervsrettede uddannelser, FORA. Undervisningsministeriet.

Bosch, Gerhard and Jean Charest 2008. Vocational training and its links with education and the labour market in five countries in R Blanpain et. Al: Challenges of European employment relations, Alphen aan den Rijn, The Netherlands: Kluwer Law International.

Bowman, John R. 2005. Employers and the Politics of Skill Formation in a Coordinated Market Economy: Collective Action and Class Conflict in Norway, Politics and Society 2005 33: 567

Breen, R. 2005. "Explaining Cross-national Variation in Youth Unemployment: Market and Institutional Factors”, European Sociological Review 21(2): 125-34.

BYN, Byggnadsindustrins Yrkesnämnd. På internet (2010): http://www.byn.se/byn/default.asp

BYN, Byggnadsindustrins Yrkesnämnd. Årsrapport 2009 - BYN i hela Sverige. På internet (2010): http://www.byn.se/byn/docs/byn_arsrapport_2009.pdf

CEDEFOP. Comparative Presentation. 1002 - Funding for initial vocational training: Introduction (www.trainingvillage.gr).

DA, Dansk Arbejdsgiverforening 2009: Arbejdsmarkedsrapport 2009 Erhvervsuddannelser - optag, frafald og beskæftigelse, http://www.da.dk/bilag/AMR09,Arbejdsmarkedsrapport \%202009.pdf

DCUM, Dansk Center for Undervisningsmiljø 2006: Analyse af frafald på erhvervsuddannelserne og social- og sundhedsuddannelserne, Undervisningsmiljøet som underliggende fokus, Analyserapport, http://www.dcum.dk/webfm_send/414

Degree 882/2010. Valtioneuvoston asetus koulutustoimikuntajärjestelmästä [Government Degree on the Vocational Standing Committees].

Dionisius, R. Muehlemann, S., Pfeifer, H., Walden, G., Wenzelmann, F. och Wolter, S. (2008), "Cost and Benefit of Apprenticeship Training - A Comparison of Germany and Switzerland", CESifo Working paper nr 2287.

Drexel, Ingrid (1989): Der schwierige Weg zu einem neuen gesellschaftligen Qualifikationstyp", Journal fur Sozialforschung, 29. Jg (1989), Heft 3:301-325

Ds 2000:62, Samverkan mellan skola och arbetsliv. Om möjligheterna med lärande i arbetslivet. 
ECY, Elbranschens Centrala Yrkesnämnd - Statistik anställda/registrerade lärlingar 1995-2009. På internet: (2010): http://www.ecy.com/larare/statistik.asp

ECY, Elbranschens Centrala Yrkesnämnd. På internet (2010): http://www.ecy.com/

Eilertsen, Roar, og Marit Wold (1991): Hjelpepleiernes plass i framtidas sykehus. Oslo: De Facto.

Elín Thorarensen \& María Kristín Gylfadóttir (2010): Starfsgreinaráð og starfsgreinanefnd. Stefna og verklag. Reykjavík: Mennta- og menningarmálaráðuneytið.

http://bella.mrn.stjr.is/utgafur/starfsgr_og_starfsgrnefnd_2010.pdf

Erichsen, Vibeke (red.) (1996): Profesjonsmakt - På sporet av en helsepolitisk tradisjon. Bergen. Tano Aschehoug.

Eurostat Labour Survey 2009. http://epp.eurostat.ec

Eurybase - The information database on education systems in Europe. Norway (www.eurydice.org).

Finansministeriet 2010 Scenarier for det fremtidige behov for udvalgte faggrupper af uddannet arbejdskraft i den offentlige sektor, København, www.fm.dk/

Finanspolitiska rådets rapport (2010) Svensk finanspolitik. Stockholm: Finanspolitiska rådet

FNBE 2009. Koulutus ja työvoiman kysyntä 2020 [Education and need for manpower 2020]. Opetushallitus. Edita Prima Oy: Helsinki.

Fokus på jobb (2009) Hässleholm: Myndigheten för kvalificerad yrkesutbildning

Foredata 2008. Selvitys opetusministeriön rahoittamista valtakunnallisista koulutus- ja osaamistarpeiden ennakointihankkeista ESR-rakennerahastokaudella 2000-2006 [Review on national anticipation projects financed by the Ministry of Education]. Foredata Oy: Helsinki.

Foredata 2009. Selvitys ammatillisten osaamistarpeiden ennakointimalleista [Review on the models of anticipation of vocational skill needs]. Foredata Oy: Helsinki.

Frøseth, m: W., E. Hovdhaugen, H. Høst og N. Vibe (2010): En, to...tre? Den vanskelige overgangen. Evaluering av Kunnskapsløftet. Fra andre til tredje år i videregående opplæring. Oslo. NIFU.

Förordning (2007:1349) om försöksverksamhet med gymnasial lärlingsutbildning Förordning (2009:130) om yrkeshögskolan

Förordningen (2007:1030) med instruktioner för Arbetsförmedlingen

Gangl, Marcus, 2001: Unemployment and Labour force experience on occupational and internal Labour Markets 1992-97, European Patterns of Labour Market Entry, European Societies, 3(4)2001: p 471-94

Gestur Guðmundsson (1993) Próun starfsmenntunar á framhaldsskólastigi. (The Development of Vocational Education and Training in Iceland) Reykjavík: Menntamálaráðuneytið og Starfsmennt.

Gestur Guðmundsson (1997) Vocational Training in Iceland. Reykjavík: The Research Liaison Office. 
Globaliseringsrådets sekretariat 2006: Bilag om brancheforskydninger og nye strukturer, http://www.globalisering.dk/page.dsp?page $=89$

Goeggel, K. och Zwick, T. (2009), “Good Occupation - Bad Occupation? The Quality of Apprenticeship Training”, ZEW Discussion paper nr 09-024.

Greinert, Wolf-Dietrich (1999): Berufsqualifizierung und dritte industrielle Revolution: eine historisch-vergleichende Studie zur Entwicklung der klassischen Ausbildungssysteme, Nomos-Verlags-Gesellschaft, Baden-Baden.

Groes, Nils 2005. Blæse og ha' mel i munden - erhvervsskolernes dilemma. Samfundsøkonomen n5, 2005.

Grove, Knut og Svein Michelsen (2005): Lærarforbundets historie.

Gføgaard 2006

Haukur Harðarson og Fjóla María Lárusdóttir (2010) Raunfærnimat Ísland 2010

(Realkompetencevurdering, Island 2010) Reykjavik: Fræðslumiðstöð atvinnulífsins http://www.frae.is/files/Stadan_a_Islandi_HH_og_FML_1924629838.pdf

Halvorsen, Tor (1995): Sektorinteresser eller profesjonssystem? Oslo: Senter for teknologi og menneskelige verdier.

HE 165/2010. Hallituksen esitys laiksi tutkintojen ja muun osaamisen viitekehykseksi [Government Bill on the National Qualifications Framework]

Helen Wiliamsdóttir Gray: National Research Report 2009. Cedefop: refernet

Humlum, Maria Knoth 2009. Essays on Human Capital Accumulation and Educational Choices,Phd. Dissertation, Faculty of Social Sciences, Aarhus University.

Høst, Håkon og Svein Michelsen (2010): Ungdom, lærlingordning og overgang til arbeidsmarkedet - endringer fra 1994 til 2008. I Søkelys på arbeidslivet 3/2010Høst, Håkon og Miriam Evensen (2009): Ny struktur - gamle mønstre? Evaluering av Kunnskapsløftet. Oslo. NiFU STEP.

Høst, Håkon (red.) (2008): Fag-og yrkesopplæringen i Norge - noen sentrale utviklingstrekk. Oslo. NIFU STEP rapport 20/2008.

Høst, Håkon (2006): Utdanningsreformer som moderniseringsoffensiv. En studie av hjelpepleieryrkets rekruttering og dannelseshistorie, 1960-2006. Avhandling for graden dr.polit. Institutt for administrasjon og organisasjon. Samfunnsvitenskapelig fakultet, Universitetet i Bergen.

Høst, Håkon (2006): Kunnskapsstatus vedrørende rekruttering og utdanning til pleie- og omsorgstjenestene i nordiske land. Notat 4 - 2006. Rokkansenteret. Universitetet i Bergen.

Michelsen, Svein, Håkon Høst og Jens P. Gitlesen (1998): Fagopplæring og organisasjon mellom reform og tradisjon. En evaluering av Reform 94. Sluttrapport.

AHS - gruppe for flerfaglig arbeidslivsforskning. Universitetet i Bergen.

Iðunn Kjartansdóttir (2007): Hvað hefur haft áhrif á námsval iðn- og verknámsnemenda? (ikke-publiceret MA opgave,Uddannelses-og erhvervsvejledning. Islands Universitet, The School of Education.)

Ingi Bogi Bogason (2005) Menntakerfi sem uppspretta.(unpublished M.A. Thesis, Human Resource Management, The School of Social Sciences at the University of Iceland. 
Jón Torfi Jónasson (1990): Menntun og skólastarf á Íslandi í 25 ár 1985-2010. Reykjavík.

Jónas H. Haralz (1965) „Um áætlanagerð” Úr pjóðarbúskapnum 14, Reykjavík. Jæger, Mads Meier \& Holm, Anders 2007: Does Parents Economic, Cultural, and Social Capital Explain the Social Class Effect on Educational Attainment in the Scandinavian Mobility Regime? Social Science Research, 36: 719-744.

Jørgensen, C.H. and I.Juul 2011. Challenges for the dual system and the occupational self-governance in Denmark, Journal of Vocational Education and Training Vol 63, No.3. p. 289-303

Jørgensen, C.H. and I.Juul 2010. Bedre samspil mellem skolepraktik og ordinær virksomhedspraktik, København, Undervisningsministeriet.

Jørgensen, Christian Helms \& Christensen, Stine Sund \& Hansen, Hanne Hvitfelt 2009: Faglighed i fremtidens tekniske erhvervsuddannelser - analyse af faglighedens rolle i unges karriereveje, København, Industriens Uddannelser.

Jørgensen, Christian Helms \& Katrine Lindvig 2011. Hybrid Qualifications Country report Denmark 2, Views and experiences of stakeholders . http://hq-lll.eu

Jørgensen, Christian Helms 2006: Utbildningsplanering: samspel mellan utbildning och arbete. Lund, Studentlitteratur.

Jørgensen, Christian Helms 2010. Hybrid Qualifications Country report Denmark 1. http://hq-lll.eu

Jørgensen, Christian Helms 2011. Frafald i erhvervsuddannelserne. Frederiksberg, Roskilde Universitetsforlag.

Jørgensen, Christian Helms m. fl. 2006: Hvorfor oprettes der ikke praktikpladser?, Øje på uddannelse LandsOrganisationen, København.

Jørgensen, Henning og Per Kongshøj Madsen (eds.) 2007: Flexicurity and beyond, København, DJØF Forlag.

Korsnes, Olav 1996: Industri og samfunn. Framlegg til et program for studiet av norsk arbeidsliv. Dr. philos-avhandling Sosiologisk Institutt/AHS - Gruppe for flerfaglig arbeidslivsforskning, Universitetet i Bergen.

Kristjana Stella Blöndal \& Jón Torfi Jónasson (2010) Frafall i skolen ot tiltak mot frafall på Island: Ulike perspektiver" in Eifred Markussen Frafall i utdanning for 16-20-åringer i Norden. København: Nordisk Ministerråd

Kupfer, A. 2010. The socio-political significance of changes to the vocational education system in Germany. British Journal of Sociology of Education, 31: 1, 85-97

Kuusi, H. 2008. Ennakointi koulutustoimikunnissa [Anticipation work in the Vocational Standing Committees]. Opetushallitus. Multiprint Oy: Helsinki.

Kvikstad \& Löken (1963) Yrkesopplæringen i Island. Oslo

Lag (2009:128) om yrkeshögskolan

Lassen, Morten 1986: Leverandørforholdet og styring af grunduddannelserne, Betænkning om Erhvervsuddannelserne 1987.

Lehman, W. (2005), “'I'm Still Scrubbing the Floors': Experiencing Youth Apprenticeships in Canada and Germany”, Work, Employment and Society, 19 (1), s. 107-129. 
Lpf 94, Läroplan för de frivilliga skolformerna

Lög um framhaldsskóla nr. 92/2008, (The Upper Secondary School Act, No. 92, 12 June 2008). Nordisk Statistik 2009

http://www.norden.org/da/publikationer/publikationer/2009-001

Markussen, E. 2010. Frafall i utdanning for 16-20 åringer i Norden, København. Nordic Council of Ministers.

Melby, Kari 1990: Kall og kamp - Norsk Sykepleierforbunds historie. Norsk Sykepleierforbund og J.W. Cappelens Forlag A.S.

Michelsen, Svein og Håkon Høst (2002): Some remarks on Norwegian Education and Training Policies and Lifelong Learning. I Klaus Harney et al. (ed.): Lifelong Learning: One Focus, Different Systems. Frankfurt am Main: Peter Lang.

MoE 2007. Koulutus ja tutkimus 2007-2012. Kehittämissuunnitelma [Development Plan for Education and Research 2007-2012]. Ministry of Education http://www.minedu.fi/export/sites/default/OPM/Julkaisut/2008/liitteet/opm0 9.pdf

Müller, Walter \& Shavit, Yossi 1998: The institutional embeddedness of the stratification process: a comparative study of qualifications and occupations in thirteen countries, in Yossi Shavit \& Walter Müller (eds) From School to Work, A Comparative Study of Educational Qualifications and Occupational Destinations, Oxford: Clarendon Press, pp. 1-48.

Müller, Walter 2005: Education and Youth Integration into European Labour Markets, International Journal of Comparative Sociology 2005; 46; 461.

Myndigheten för yrkeshögskolan - Om myndigheten för yrkeshögskolan. På internet (2010): http://www.yhmyndigheten.se/hem/om-oss/om-oss/

Myndigheten för yrkeshögskolan (2010a) Årsredovisning 1 juli - 31 december 2009. Västerås: Myndigheten för yrkeshögskolan

Myndigheten för yrkeshögskolan (2010b) Uppföljning av Ky-studerandes sysselsättning ett år efter examen. Stockholm: Myndigheten för yrkeshögskolan.

Myndigheten för yrkeshögskolan (2010c) Utbildningsanalys 2010 - Myndigheten för yrkeshögskolans analys av arbetslivets efterfrågan på kompetens. Stockholm: Myndigheten för yrkeshögskolan.

NAOF 2008. Koulutuksen määrällinen ennakointi, mitoitus ja kohdentaminen; erityiskohteena nuorten ammatillinen peruskoulutus [Quantitative anticipation, dimensioning and allocation of education in the field of basic vocational training for youth]. Tarkastuskertomus 171/2008. Edita Prima Oy: Helsinki.

Nyhetsbrev, Folkpartiet - Stora satsningar på utbildning. På internet (2010): http://www.folkpartiet.se/Jan-Bjorklund/Nyhetsbrev/?nid=115535

OECD, (1994), Apprenticeship: Which way forward?

OECD, (2009), Learning for Jobs. OECD Policy Review of Vocational Education and Training. Initial Report.

Olofsson, J. \& Panican, A. (red.) 2008. Ungdomars väg från skolan till arbetsliv nordiska erfarenheter. Köpenhamn: Nordiska Ministerrådet 
Olofsson, J. \& Wadensjö, E. (2006) Lärlingsutbildning - ett återkommande bekymmer eller en oprövad möjlighet? Stockholm: Regeringskansliet

Olofsson, J. \& Wadensjö, E. (2009) Arbetsmarknadspolitik - förändrade förutsättningar och nya aktörer. Stockholm: SNS

Olofsson, J. (2005) Svensk yrkesutbildning - vägval i internationell belysning. Stockholm: SNS Förlag

Olofsson, J. (2005), Svensk yrkesutbildning. Vägval i internationell belysning, Stockholm: SNS Förlag.

Olofsson, J. (2007) “Utbildning - vägen till frälsning?” i Jonas Olofsson red.: Utbildningsvägen - vart leder den? Om ungdomar, yrkesutbildning och försörjning. Stockholm: SNS Förlag

Olofsson, J. (2010) Krisen i skolan - utbildning i politiken och i praktiken. Umeå: Boréa

Olofsson, J. och Wadensjö, E. (2006), „Lärlingsutbildning - ett återkommande bekymmer eller en oprövad möjlighet?" Rapport till ESS 2006:4.

Olofsson, J. och Wadensjö, E. (2011), Lärlingsutbildning, Stockholm: SNS Förlag.

Olofsson, Jonas 2005. Svensk yrkesutbildning: vägval i internationell belysning, SNS Förlag.

Prop. 2010/11:104, Kvalitet i gymnasial lärlingsutbildning.

Proposition 2008/09:199 Högre krav och kvalitet i den nya gymnasieskolan.

Ryan, P. (1998), "Is Apprenticeship Better? A Review of the Economic Evidence”, Journal of Vocational Education and Training, 50 (2), s. 289-325.

Ryan, P. (2003), "Evaluating Vocationalism”, i European Journal of Education, nr 2.

SCB (2009), „Arbetsmarknadssituationen för hela befolkningen 15-74 år”, AKU 2:a kvartalet 2009. Tema - att jämföra ungdomsarbetslösheten i Europa.

SCB (2010), Lokala arbetsmarknader - egenskaper, utveckling och funktion.

Schober-Brinkmann, K. och Wadensjö, E. (1991), „Contrasting Forms of Youth Training and Employment in Sweden and FR Germany”, i Ryan, P., Garonna, P. och Edwards, R.C. (red.), The Problem of Youth. London: Macmillan.

Schröder, L. (1991), Springpojkar och språngbrädor. Om orsaker till och åtgärder mot ungdomars arbetslöshet. Stockholm: Institutet för social forskning, avhandlingsserie $\mathrm{nr} 18$.

SFS 1943:963, Kungl. Maj:ts Instruktion för överstyrelsen för yrkesutbildning.

SFS 2007:1349, Förordning om försöksverksamhet med gymnasial lärlingsutbildning.

SFS 2009:1077 - Förordning om ändring i förordningen (2009:43) om statsbidrag för yrkesinriktad gymnasial vuxenutbildning.

SFS 2009:43 - Förordning om statsbidrag för yrkesinriktad gymnasial vuxenutbildning

SFS 2010:2039, Gymnasieförordning; utfärdad den 22 december 2010.

Shavit, Y. och Müller, W. (2000), "Vocational Secondary Education. Where Diversion and Where Safety Net?", European Societies, 2 (1), s. 29-50. 
Skill needs in Europe. Focus on 2020. Cedefop Panorama Series; 160. Luxembourg 2008.

Skolverket (2009) Redovisning av regeringsuppdrag att förbereda och genomföra insatser inom yrkesvux.

Skolverket (2010) Beslut om 2010 års lärlingsplatser

Skolverket (2010) Om Yrkesvux

Skolverket (2010) Skolor och elever i gymnasieskoan läsår 2009/10

Skolverket (2010) Uppgifter på riksnivå, elever på program fördelat efter kön läsåret 2009/10, Tabell $4 \mathrm{~A}$

Skolverket PM - Elever och studieresultat i komvux kalenderår 2009

Skålholt, Asgeir og Håkon Høst (2010): Helsefagarbeiderlærlinger i sjukehus. Oslo. NIFU STEP

Soskice, D. (1994), "Reconciling Markets and Institutions: The German Apprenticeship System”, i Lynch, L. M. (red), Training and the Private Sector.

SOU 1948:27, 1946 års skolkommissions betänkande med förslag till riktlinjer för det svenska skolväsendets utveckling.

SOU 1966:3, Yrkesutbildningsberedningen.

SOU 2008:27 Framtidsvägen - en reformerad gymnasieskola. Stockholm: Fritze

SOU 2009:85 Gymnasial lärlingsutbildning - hur blev det? Erfarenheter från första försöksåret. Stockholm: Fritze.

SOU 2010:19 Lärling - en bro mellan skola och arbetsliv. Stockholm: Fritze

SOU 2010:19, Lärling - en bro mellan skola och arbetsliv.

SOU 2010:75, Gymnasial lärlingsutbildning - utbildning för jobb. Bilaga 4. Lemar,

S. \& Olofsson, J., Om lärlingsrådens funktioner.

Starfsnámsnefnd (2006): Nýr framhaldsskóli. Skýrsla

starfsnámsnefndar.Reykjavik: menntamálaráduneyti.

http://refernet.is/page/utgafur

Statistics Finland 2010. Oppilaitostilastot 2009 [Educational institutions]. Multiprint Oy: Helsinki.

Steedman, Hilary 2005 Apprenticeship in Europe: 'Fading' or Flourishing? CEP Discussion Paper No 710, London, Centre for Economic Performance, http://eprints.lse.ac.uk/19877/

Streeck, W. 1992. Social institutions and economic performance: studies of industrial relations in advanced capitalist economies, London, Sage.

Svarer, Michael 2006 Fremtidens arbejdskraftefterspørgsel - Uddannelse og arbejdsmarkedet, Institut for Økonomi, Aarhus Universitet. Oplæg til Globaliseringsrådet. http://www.uvm.dk

Szydlik, Marc 2002: Vocational education and labour markets in deregulated, flexibly coordinated and planned societies, i European Societies Vol $4 \mathrm{nr} 1$ 2002: 79-105

Um nýskipan verk- og tæknimenntunar á Íslandi. Nefndarálit (1971) Reykjavík: menntamálaráðuneytið. 
Undervisningsministeriet 2010 Måltal for erhvervsuddannelser - relevans målt i form af beskæftigelsesfrekvens, www.uvm.dk

Undervisningsministeriet 2010: De faglige udvalgs udviklingsredegørelser for 2010 - sammenfatning og videre perspektiver. København, Undervisningsministeriet

Undervisningsministeriet 2010: Strategiske fokusområder VEU-rådet - maj 2010. http://www.uvm.dk

Ungt fólk án atvinnu - virkni pess og menntun, skýrsla vinnuhóps félags- og tryggingaráðuneytis og mennta- og menningarráðuneytis. Reykjavik: november 2009. http://www.felagsmalaraduneyti.is/utgefid-efni/utgafa/nr/4587

Velfærdskommissionen 2006. Fremtidens velfærd - vores valg, København, Finansministeriet, http://www.fm.dk/Publikationer.aspx

Nils Vibe, Synnøve Skjersli Brandt \& Elisabeth Hovdhaugen (2011): Underveis i videregående opplæring. Evaluering av Kunnskapsløftet. Underveisrapport fra prosjektet Struktur, gjennomføring og kompetanseoppnåelse. NIFU rapport 19/2011, Oslo: NIFU

VVS, Värme, Ventilation och Sanitets branschens yrkesnämnd - Branschprov. På internet (2010): http://www.vvsyn.se/Templates/Vvsyn15.aspx

VVS, Värme, Ventilation och Sanitets branschens yrkesnämnd. På internet (2010): http://www.vvsyn.se/Templates/Vvsyn1.aspx

Wolbers, Maarten H. J. 2007: Patterns of Labour Market Entry A Comparative Perspective on School-to-Work Transitions in 11 European Countries, Acta Sociologica, September 2007, Vol 50(3): 189-210.

Zwick, T. (2007), "Apprenticeship Training in Germany - Investment or Productivity Driven?”, ZEW Discussion paper nr 07-023.

Aamodt, Høst, Arnesen og Næss (2011) Evaluering av Kompetanseløftet 2015. Underveisrapport 3. Oslo. NIFU 